\title{
A Decommissioning Plan for the Heavy Water Components Test Reactor
}

by

M. B. Owen

Westinghouse Savannah River Company

Savannah River Site

Aiken, South Carolina 29808

F. R. Field

DOE Contract No. DE-AC09-89SR18035

This paper was prepared in connection with work done under the above contract number with the U.S. Department of Energy. By acceptance of this paper, the publisher and/or recipient acknowledges the U.S. Government's right to retain a nonexclusive, royalty-free license in and to any copyright covering this paper, along with the right to reproduce and to authorize others to reproduce all or part of the copyrighted paper. 


\section{DISCLATMER}

This report was prepared as an account of work sponsored by an agency of the United States Government. Neither the United States Government nor any agency thereof, nor any of their employees, makes any warranty, express or implied, or assumes any legal liability or. -responsibility for the accuracy, completeness, or usefulness of any information, apparatus, product, or prooess disclosed, or represents that its use would not infringe privately owned rights. Reference herein to any specific commercial product, process, or service by trade name, trademark, manufacturer, or otherwise does not necessarily constitute or imply its endorsement. recommendation, or favoring by the United States Government ar any agency thereof. The views and opinions of authors expressed herein do not necessarily state or reflect those of the United States Government or any agency thereof.

This report has been reproduced directly from the best available copy.

Available to DOE and DOE contractors from the Office of Scientific and Technical Information, P.O. Box 62, Oak Ridge, TN 37831; prices available from (615) 576-8401.

Available to the public from the National Technical. Information Service, U.S. Department of Commerce, 5285 Port Royal Road, Springfield, VA 22161. 


\section{A DECOMMISSIONING PLAN FOR THE HEAVY WATER COMPONENTS TEST REACTOR .}

by

F. R. Field

Hork done by

J. H. Crawford, T. C. Gorrell,

W. R. Jacobsen, H. P. Olson, and T. A. Wi 17 is

Approved by

S. Mirshak, Director

Nuclear Engineering and Materials Section

(As of August 1975)

Publication Data: January 1976

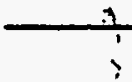

E. I. DU PONT DE NEMOURS AND COMPANY

SAVANNAH RIVER LABORATORY

AIKEN, SOUTH CAROLINA 29801

PREPARED FOR THE U.S. ENERGY RESEARCH AND DEYELOPMENT ADMINISTRATION UNDER CONTRACT AT(0T.2)-I 


\section{DISCLAIMER}

Portions of this document may be illegible in electronic image products. Images are produced from the best available original document. 


\section{CONTENTS}

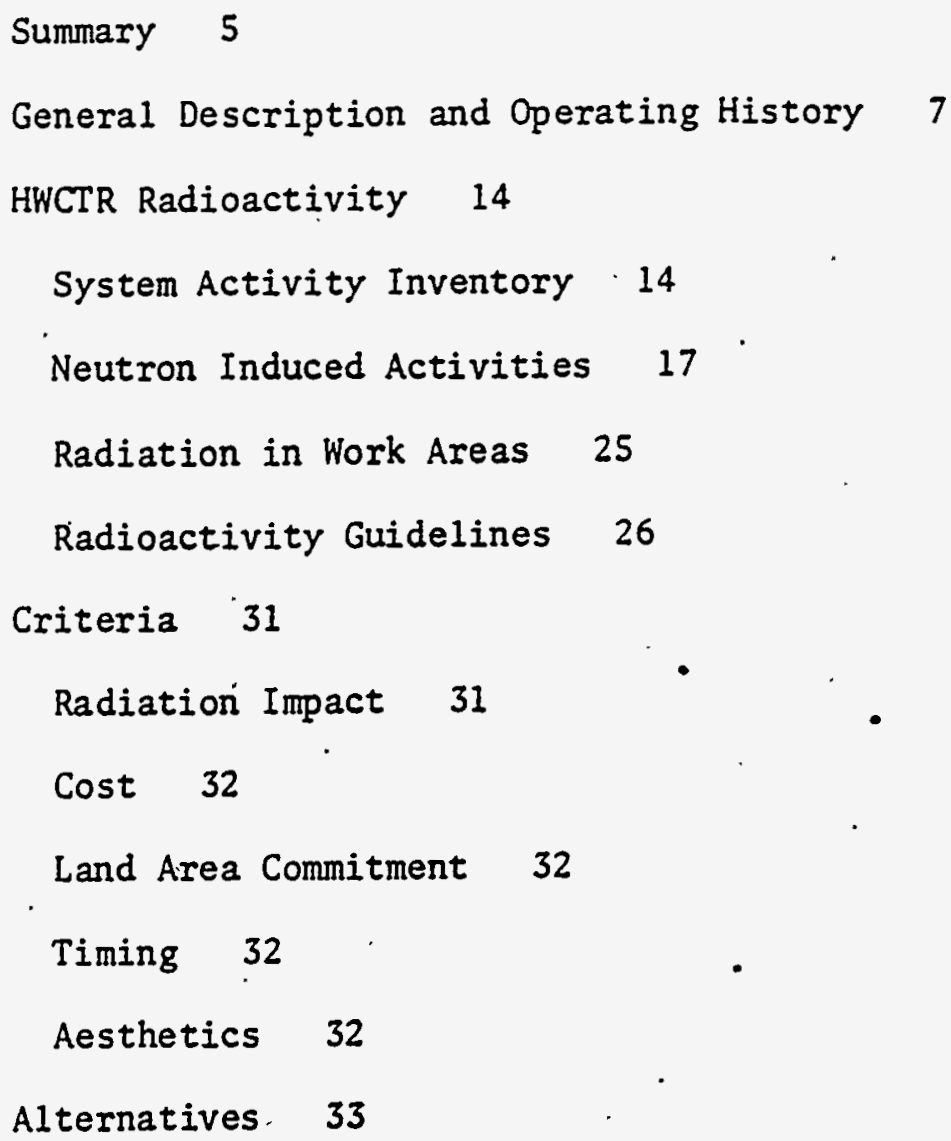


FOREWORD

Preparation of a decommissioning plan for the Heavy Water Components Test Reactor (HWCTR) was authorized by ERDA-DHMT as part of the FY 1975 budget. The results of the planning effort are documented herein. 


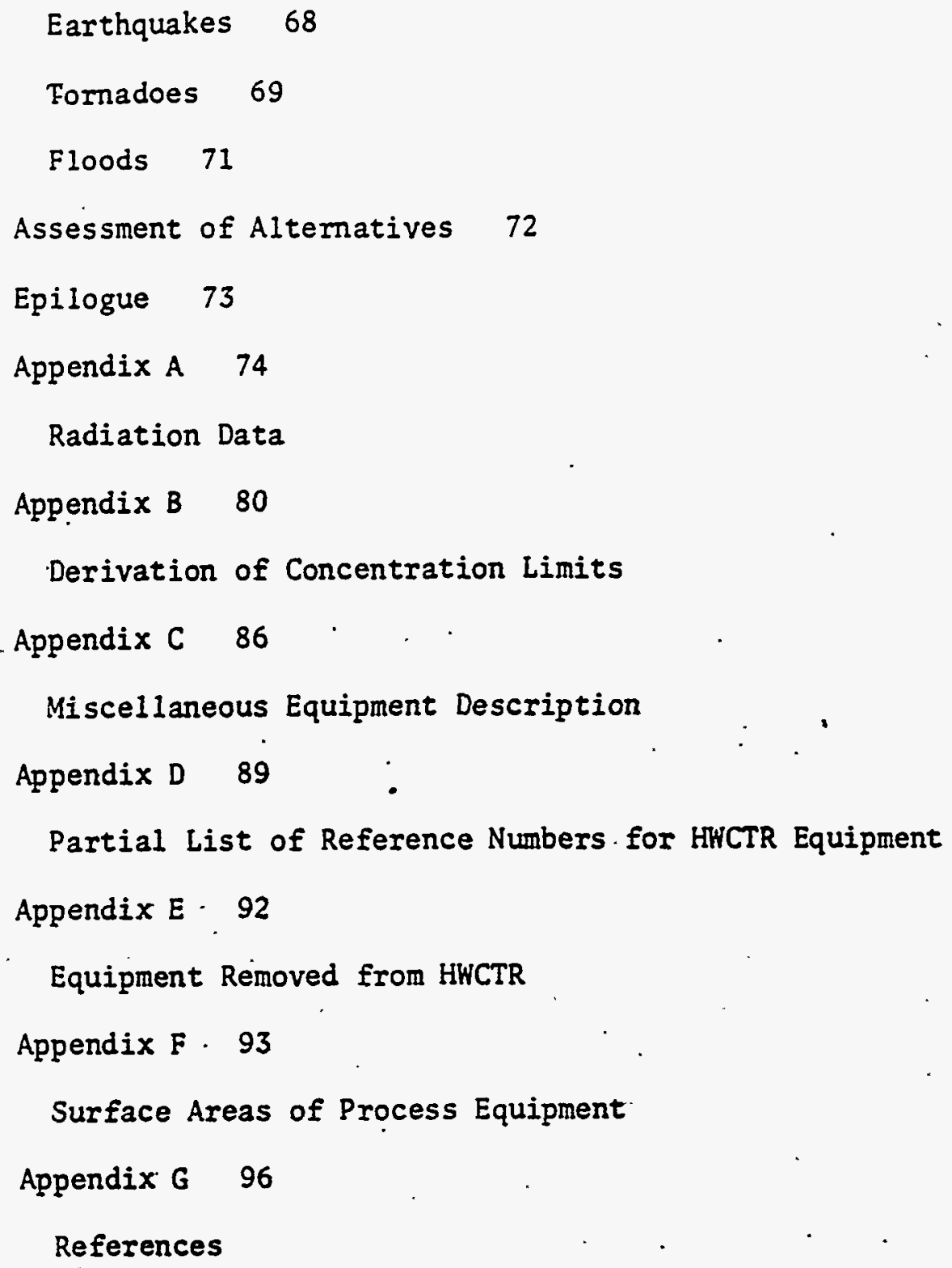




\section{A DECOMMISSIONING PLAN FOR THE HEAVY WATER COMPONENTS TEST REACTOR}

\section{SUMMARY}

Three alternatives to decommission the Heavy Hater Components Test Reactor (HWCTR) have been analyzed as summarized in Table 1. The protective confinement approach is advantageous as long as current activities onsite limit access by the general public; excellent confinement of the residual activity is provided by in situ dry storage as the radiation from ${ }^{6} 60$ diminishes. Entombment provides the most-secure confinement of the activity but at some increased cost. Dismantling HWCTR has no apparent advantages other than a demonstration at the Savannah River.Plant site, because of the long-term commitment to safeguarding radioactive material; the relative cost is high.

The induced radioactivity in HWCTR is currently $2.3 \times 10^{4}$ Ci; general area radiation levels are typically $3 \mathrm{mR} / \mathrm{hr}$. In 35 years, the decay of ${ }^{\circ} \mathrm{Co}$ will lower the radiation levels by a factor of 100 , and the remaining radioactivity will be $2 \times 10^{3}$ $\mathrm{Ci}$ of ${ }^{63} \mathrm{Ni}$. Minimal offsite effects are calculated to result after postulated structural failures to the decommissioned HWCTR facility.

Flexibility and aesthetics favor dismantlement, but these criteria are considered less significant than public radiation dose, cost, and land area committed. 
TABLE 1

Summary of Decommissioning Options

Dismantlement

Remove all radioactive

equipment to

burial ground

Radiation Exposure

Accidental to Public

Planned Occupational, rem

Land Area, acres

HWCTR

Burial Ground

Water Rights, acres

Capital Cost, $\$$ millions ${ }^{a}$

Annual Cost, \$

Flexibility

Aesthetics

\section{Unlikely}

20

0

2

Burial site to creeks (already needed)

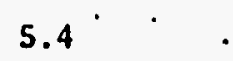

$<100$

Best

Best
Entombment

Relocate above-grade equipment to burial

ground, and fill

building. with concrete

Extremely unlikely

1.5

0.2

Fróm 0 to 90 (HWCTR to creek)

1.6

1500

Poor

Good
Protective Confinement

Repair dome, seal building, and seal piping system

Very unlikely

$<1$

1.5

0

90 (HWCTR to creek)

0.19

3000

Good

Least attractive

4. Current appraisal of cost for evaluation only, based on January 1978 authorization. 


\section{GENERAL DESCRIPTION AND OPERATING HISTORY}

The Heavy Water Components Test Reactor (HWCTR) was operated from October 1961 to December 1964 to test fuel elements and other reactor components of potential use in heavy water moderated and cooled power reactors. Operations were terminated, and the facility was placed in standby condition as a result of the decision by the U. S. Atomic Energy Commission to redirect the research and development work on heavy water power reactors to reactors cooled with organic materials. For about one year, the facility was maintained so that operation could readily be resumed. Subsequently, the facility was retired in place with monthly surveillance by reactor personnel from a nearby facility.

The HWCTR site is located in $U$ area, which is three miles from the nearest major production site at the Savannah River Plant (SRP), and also about three miles from the nearest plant boundary. The area outside the plant boundary within a radius of ten miles of $U$ area is sparsely populated, particularly within two or three miles of the Savannah River.

The location of the HWCTR facilities within $U$ area is shown in Figure 1. An aerial photograph of the site is shown in Figure 2 .

A cutaway view of the containment building is shown in Figure 3. The building is $70 \mathrm{ft}$ in diameter and $125 \mathrm{ft}$ high. Approximately half of the building is below grade and is prestressed concrete; the upper half is carbon steel. The building is designed to withstand an internal pressure of $24 \mathrm{psig}$ and was tested pneumatically at 29 psig. The containment building houses the reactor and coolant systems, the charge-discharge mechanisms, and the reactor instrumentation.

A cutaway view of the reactor pressure vessel is shown in Figure 4. The vessel has an overall height of $30 \mathrm{ft}$, with a core-region height of $10 \mathrm{ft}$ and a diameter of $7 . \mathrm{ft}$. The shell and head are carbon steel; all interior surfaces are clad with stainless steel, 0.25 -inch nominal thickness. The 3 -inch radial thermal shield is stainless steel.

The core consists of a central region of 12 test assemblies surrounded by a ring of 24 driver fuel assemblies, enriched in ${ }^{25} \mathrm{U}$.; Control rods, safety rods, and instrument thimbles were. interspersed throughout the core. 


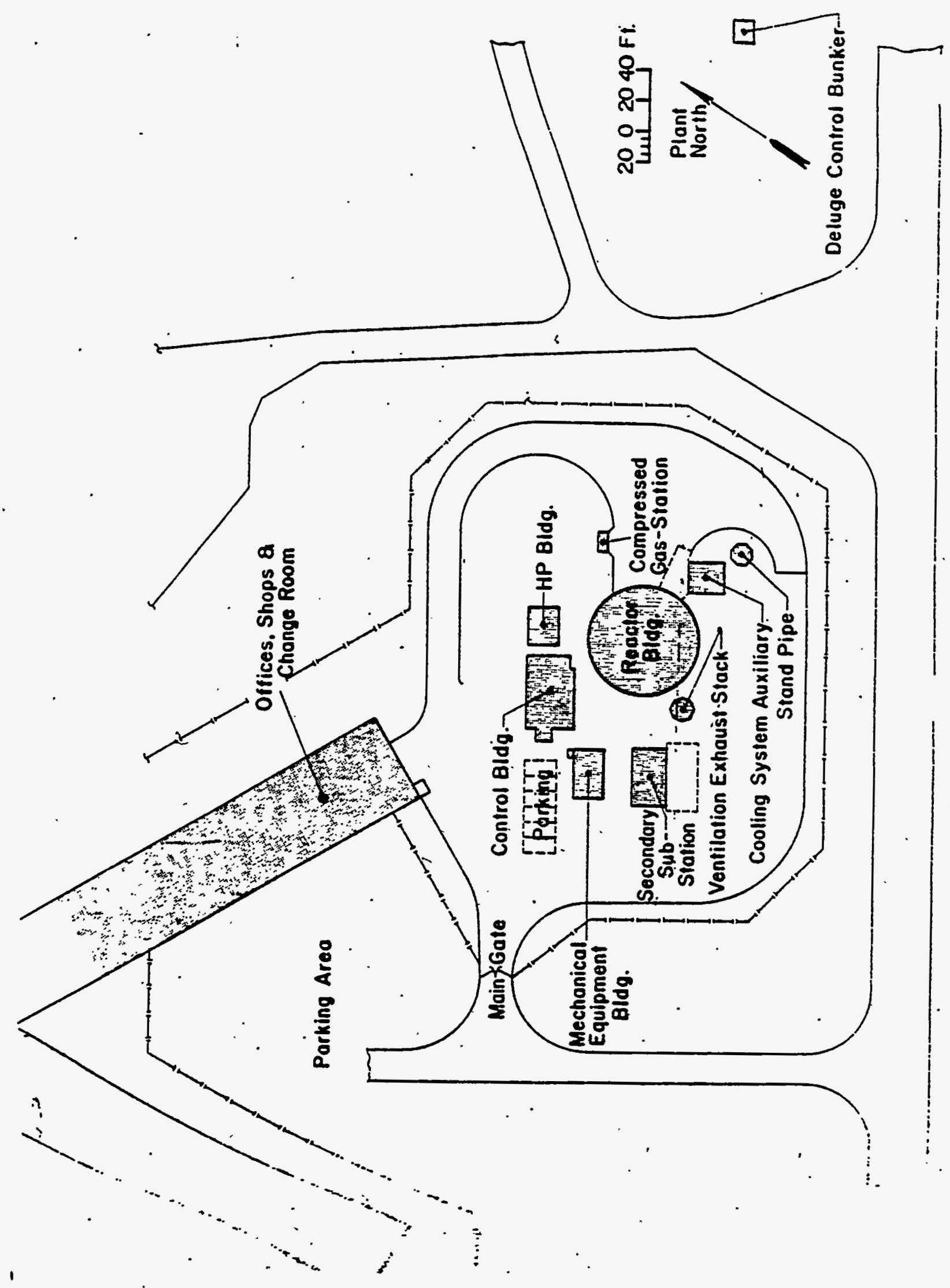

FIGURE $i$ "U-Area Building Arrangement 


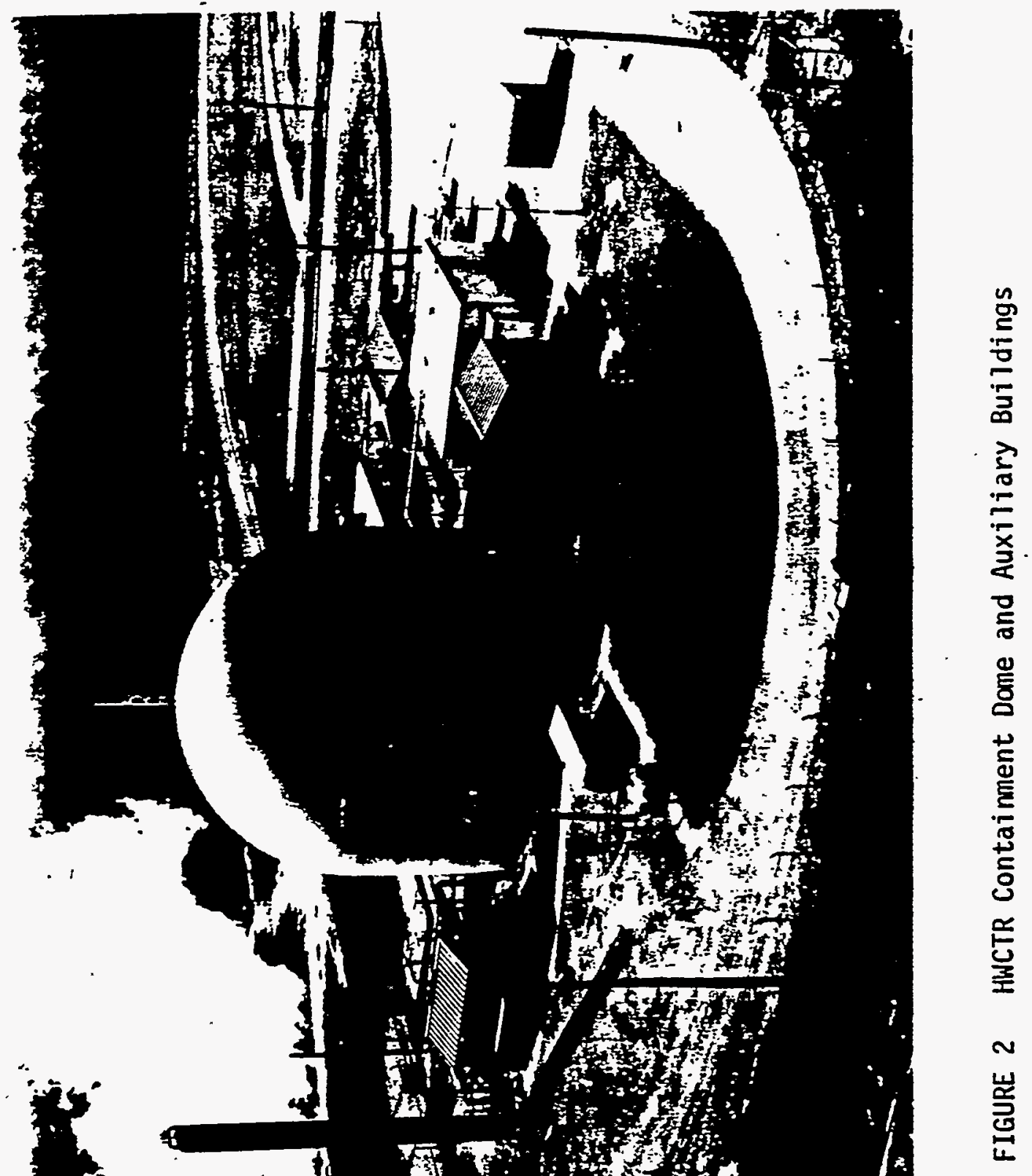




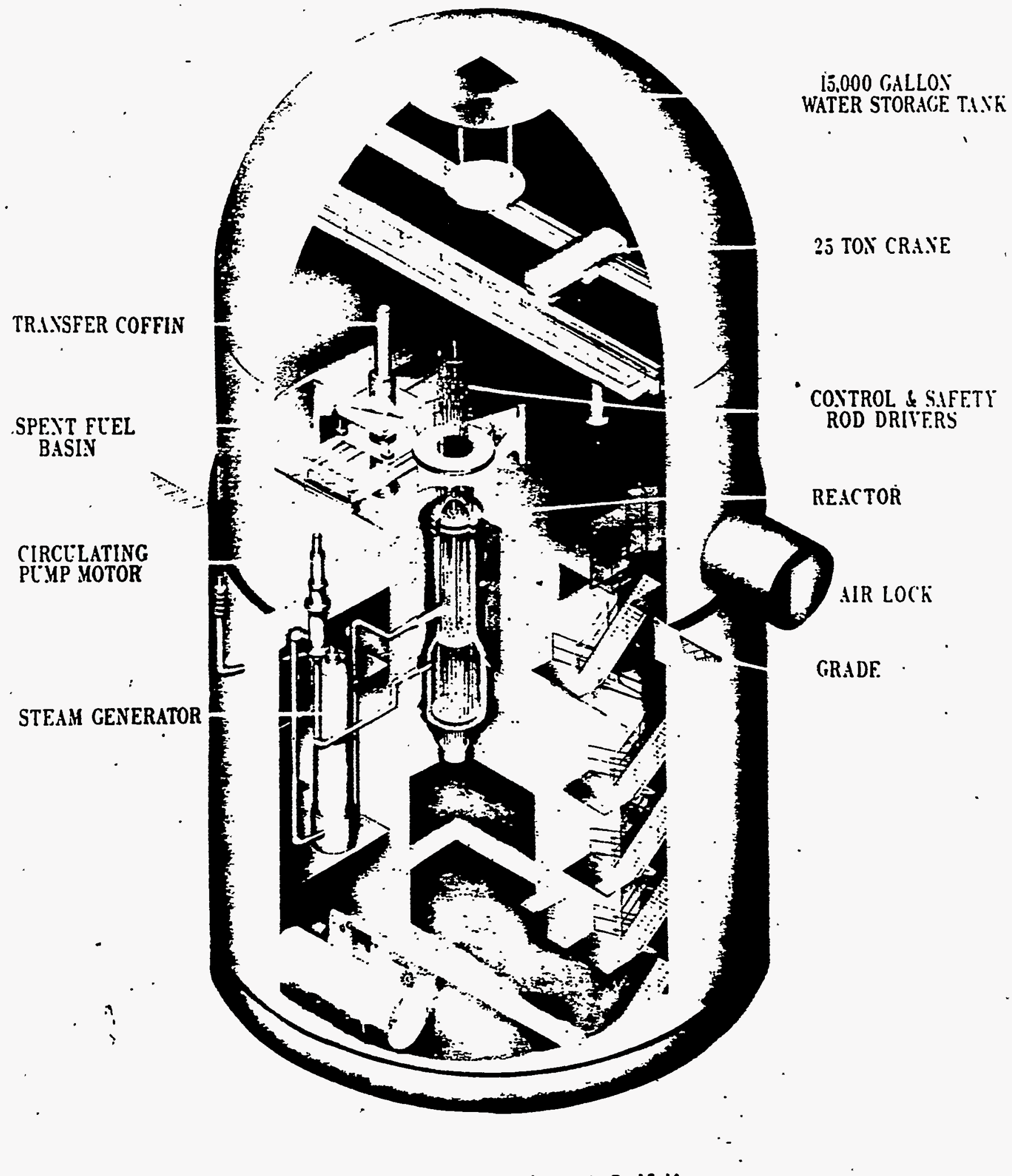

FIGURE 3. Containment Building 


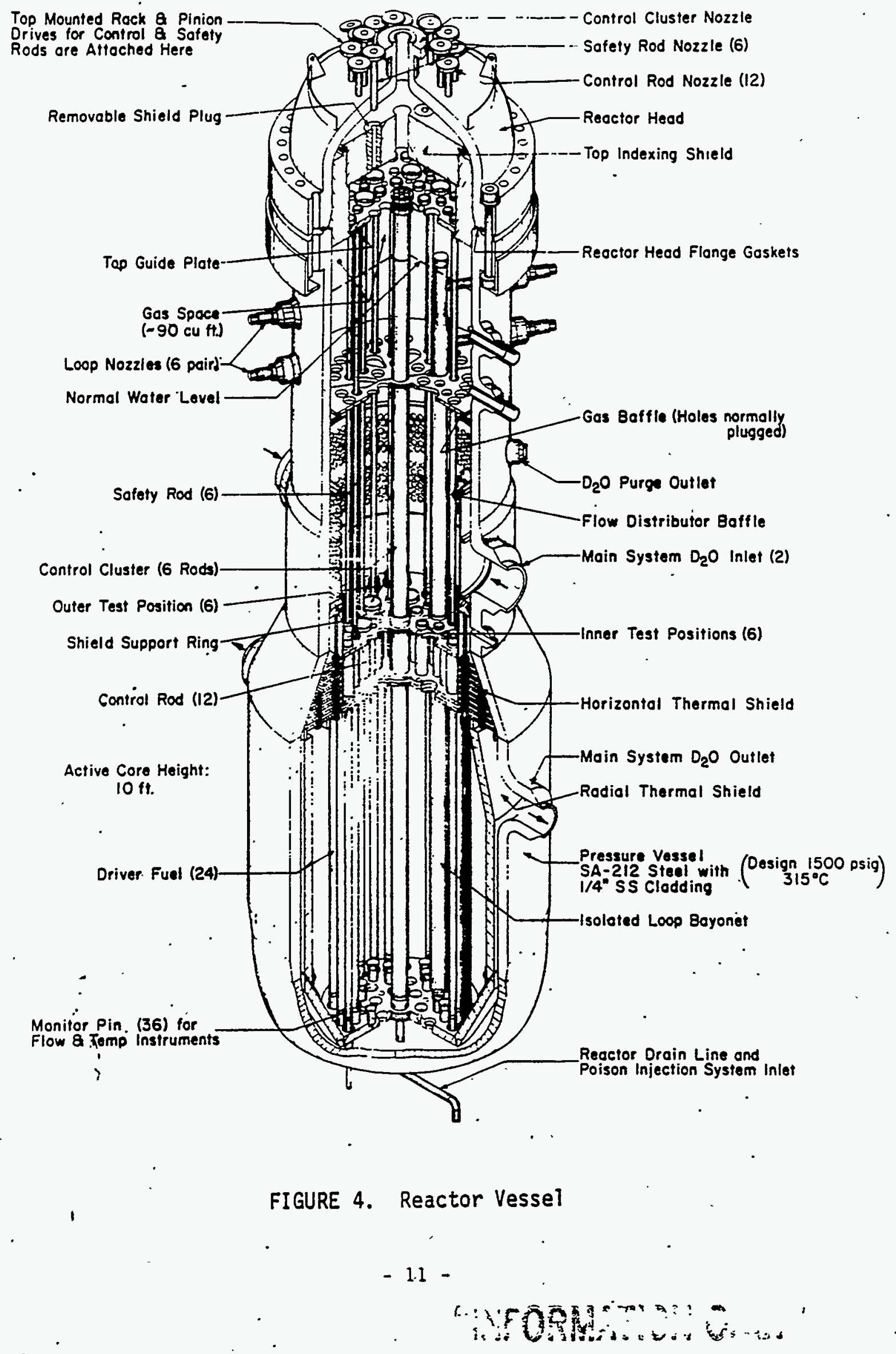


Heavy water to moderate fast neutrons and to $c 001$ the fuel was pumped through two inlet nozzles into the top section of the reactor vessel at a rate of $10,000 \mathrm{gpm}$. The flow path is down through the fuel assemblies, up through the moderator space, and out into two coolant loops. The operating conditions in the heavy water system were $1200 \mathrm{psig}$ at 230 to $250^{\circ} \mathrm{C}$; the reactor vessel was tested at $1500 \mathrm{psig}$ and $315^{\circ} \mathrm{C}$. The heavy water was cooled by boiling light water in a steam generator in each loop; the steam produced was discharged to the atmosphere.

Two test positions in the reactor core were occupied by bayonets connected to isolated coolant loops called the "Liquid Loop" and the "Boiling Loop." A bayonet consisted of two concentric tubes that formed annuli for the downward (inlet) flow and upward (outlet) flow of coolant through the test assembly. The. upper section of the bayonets and part of the extemal piping are made of stainless steel. The in-core sections are made of Zircaloy. The boiling loop bayonet failed when vibration caused a dummy housing to fret a hole in the bottom of the bayonet. The boiling loop bayonet never contained test fuel; the liquid loop bayonet contained a test assembly that failed and released, particulate. material.

During the initial hydraulic tests with light water, a protective film of magnetite.was formed on the surface of the process system. This film remained intact during the subsequent operation and, together with careful alkaline pD control, accounted for the completely satisfactory performance of the large amount of carbon steel. in the process system. Crud levels in the process systen were very low, resulting in correspondingly low transport of activated particles.

The total nuclear exposure in HWCTR was 13,882 MWD. Maximum reactor power was $50 \mathrm{MH}$. Thirty-six test assemblies containing tubular fuel of uranium metal or uranium oxide were irradiated, and the utility of this fuel for power reactors was successfully demonstrated. One assembly of tubular oxide elements reached an exposure of 17,500 MWD/Tonne. Ten failures of experimental fuel were experienced during this period. In each instance the failure was detected promptly, and the reactor was shut down before the process system became seriously contaminated.

All failed fuel assemblies were transferred to the shipping cask under water in the spent fuel basin. As a result, some contamination of the basin occurred that was not completely removed by filters and ion exchange colums. 
After the facility was shut down in 1964, all of the fuel assemblies and the two neutron sources were removed from the reactor and stored in H Area: All other reactor components including control and safety rods, long-term corrosion coupons, and a rod containing gamma ion chambers were left in the core. After the heavy water was drained from the reactor system, both the high and low pressure systems were dried and filled with nitrogen. A positive pressure was maintained from nitrogenfilled cylinders until this operation was abandoned in November 1971.

Very few changes have been made in the HWCTR system since shutdown. Radioactivity levels have decayed to low values with only a few isolated hot spots remaining. ${ }^{60} \mathrm{Co}$ is the primary detectable activity. The external appearance of components inside the containment dome is very good. The physical location and status of the HWCTR system are essentially the same as described in the standby status report. . 


\section{HWCTR RADIOACTIVITY}

- The definition of the activity present at HWCTR was subdivided into three general tasks:

- Estimate the residual activity in the carbon steel portion of the reactor hydraulic system exterior to the biological shield.

- Estimate the induced activity in the reactor vessel and adjacent concrete.

- Survey the radiation emitted in various work areas in the facility.

The activity in the carbon steel piping is shown to be small (less than $0.01 \%$ of the total) and is from deposits of activated corrosion products and adsorbed activity from fuel failures; the HWCTR test failures are described. Calculations of the activity $\left(\sim 10^{4} \mathrm{Ci}\right)$ induced in the reactor yessel (primarily the thermal shield) from flux and exposure data are corroborated by some measurements made near the vessel with special instruments (Appendix A). The good agreement between calculations and measurements supports the preliminary estimates of the induced activity in materials near the reactor. Survey data of HWCTR were used in estimating occupational doses in decommissioning. Radiation surveys of the area are compared in Appendix A, Table A-1.

\section{System Activity Inventory}

Fuel Failures

Ten test fuel assemblies (Table 2) failed during operation in HWCTR. Only two of the failures resulted in the release of uranium to the main coolant system; one failure occurred in the isolated liquid loop system.

The amount of uranium released in failures 1,2 , and 8 is uncertain. Values used in this study were 1,5 , and $5 \mathrm{~g}$, respectively. The amounts of plutonium and fission products contained in a gram of uranium were calculated from the exposure history of the assembly. Based on these calculations, approximately $4 \mathrm{mg}$ of plutonium (predominantly. ${ }^{239} \mathrm{Pu}$ ) was released to the main process system and $4 \mathrm{mg}$ to the liquid loop during HWCTR operation. The corresponding values for fission products are $6 \mathrm{mg}$ (main system) and $5 \mathrm{mg}$ (liquid loop). 
TABLE 2

Failed Test Fuel Assemblies

Assembly

No. Acronyma

1. THNT-7 Natural U Metal

2. TWNT-14 Natural U Metal

3. SOT-2-3 Natural U Oxide

4. SOT $-2-2$

5. $\mathrm{OT}-1-6$

Natural U Oxide

1.5\% Enriched

. U Oxide

6. $\mathrm{OT}-1-3$

1.5\% Enriched

U Oxide

7. SOT-5-2 Natural U Oxide

8. SOT-7-2 Natural U Oxide (Liquid Loop)

9. SOT $-9-2$

1.2\% Enriched U Oxide

10. CANDU

Natural U Oxide
HTR Report ${ }^{b}$ Number

45

47

51

54

55

56

61

65

72

76.
Estimate of

Released Uranium, $g$

0.1 to 12

0.5 to 60

Gaseous

Gaseous

Gaseous ,

Gaseous

Gaseous

About 5

Gaseous

Gaseous

a. TWNT - thin-walled nested tube

SOT - segmented oxide tube

OT - oxide tube

CANDU - fuel planned for AECL CANDU reactor (Canadian deuterium oxide cooled and moderated, uranium fueled reactor)

b. A separate HTR (HWCTR Technical Report) was written for each failure and is in the HWCTR permanent files. 
The response of the fission-gas monitors during the SOT-7-2 failure in the liquid loop was much greater than for the two metal failures, although the total uranium released was about the same. The high gas activity from SOT-7-2 is attributed to molten uranium penetrating the fission-gas collection chamber in the failed segment and driving out accumulated gases.

Considerable difficulty was encountered in reducing liquid loop activities after the failed assembly was discharged. De-. ionizer failure and pluggage occurred, and hot spots were found in several parts of the system. Deionizer replacement and special flushings were only partly successful in lowering the activity levels.

Radiation surveys made after reactor shutdown revealed high activity regions in the boiling loop inlet and outlet stubs. Recent surveys confirm the presence of above-background activity. Although the nuclides have not been identified, it is very likely that the radiation is originating from activation products deposited in the bayonet and stubs during the period prior to detection of the bayonet failure. The-bayonet contained an empty Zircaloy housing resting on a stainless steel cross. Vibration resulted in severe damage to the housing, cross, and bayonet itself, until fretting wore a hole in the bayonet. $\mathrm{D}_{2} \mathrm{O}$ in the bayonet had been isolated from main process $\mathrm{D}_{2} \mathrm{O}$ and was stagnant for a period of at least 4 months before the bayonet failed in August 1963. The $\mathrm{D}_{2} \mathrm{O}$ was known to be very turbid and to contain corrosion products of Zircaloy and stainless steel. Some of this material was probably activated in the reactor core region and migrated to and deposited on the inlet and outlet stubs, which were closed by blind flanges. The stubs were not flushed after the failed bayonet was removed.

\section{Piping Survey}

Samples were obtained from both of the liquid loops and the main process water header at the lower side of the first accessible horizontal run after leaving the reactor vessel. Smears were also taken from the bottom of the process water storage tank, EP-41. Results are summarized in Table 3; details are given in Appendix A. Less than $0.01 \%$ of the total HWCTR activity is deposited in the pipes. All pipe samples represent high side estimates of the radioactivity deposited in the system. However, the radioactivity. measured in the boiling loop is puzzling because no. assemblies. were tested in the loop. As discussed previously, a portion of the boiling loop was blanked after a bayonet failure. It is believed that activity from a fuel failure in the liquid loop subsequently contaminated the main system and the boiling loop via common piping. 
TABLE 3

Radioactivity.in the External Water Systems

\begin{tabular}{|c|c|c|c|c|}
\hline \multirow{2}{*}{\multicolumn{2}{|c|}{ Main Process Water System }} & \multicolumn{3}{|c|}{ Radiogetiyity, $C_{i}$} \\
\hline & & $\begin{array}{l}\text { TRUa } \\
170 \times 10^{-6}\end{array}$ & $\begin{array}{l}{ }^{137} \mathrm{Cs} \\
<0.6 \times 10^{-6}\end{array}$ & $\begin{array}{l}60 \mathrm{Co} \\
0.5\end{array}$ \\
\hline Liquid Loop & & $230 \times 10^{-6}$ & $<14 \times 10^{-6}$ & 0.05 \\
\hline Boiling Loop & & $380 \times 10^{-6}$ & $<35 \times 10^{-5}$ & 0.32 \\
\hline$E P-41$ & & $26 \times 10^{-6}$ & $11 \times 10^{-6}$ & $0.70 \times 10^{-3}$ \\
\hline & & $806 \times 10^{-6}$ & $11 \times 10^{-6}$ & 0.87 \\
\hline
\end{tabular}

a. $\sim 90 \%{ }^{239} \mathrm{Pu}, 108^{238} \mathrm{Pu}$ (suspected to be $<18^{2}{ }^{3}{ }^{\circ} \mathrm{Pu}$ )

Neutron Induced Activities

Calculations were made to determine the activity level's of several major system components exposed to neutron flux irradi-. ation during reactor operation. Representative radial and axial distributions of the thermal neutron flux are shown in Figures 5 and 6 . The axial flux distribution is strongly peaked near the bottom of the reactor because full length control rods were operated as a bank, and no partial length rods were used for flux shaping. Absolute values for the radial flux correspond to a total reactor power of $50 \mathrm{MH}$ midway through a fuel cycle. The axial location corresponds to the layer of maximum axial flux. The neutron flux in the concrete biological shield ist reduced a factor of 10 for each 9 inches of concrete. Tíeshield wall between the reactor and tho stainweff is about $11 \mathrm{ft}$ ! thick?

\section{Radioactive Nuclides}

A review of potential activation products in stainless steel and carbon steel showed that only three nuclides contribute significt iste induced activity 10 years after reactor shutdown 3 viz. regions of interest was relatively low, no multiple neutron captures need to-be considered in the formation of any of the three nuclides. Rather, the concentrations can be calculated from nuclear data related only to the nuclide and its immediate precursor. Activities were calculated from thermal neutron fluxes and $2200 \mathrm{~m} / \mathrm{sec}$ cross sections without a Maxwellian-distribution term; reactions from epithermal neutrons were not treated explicitly. 


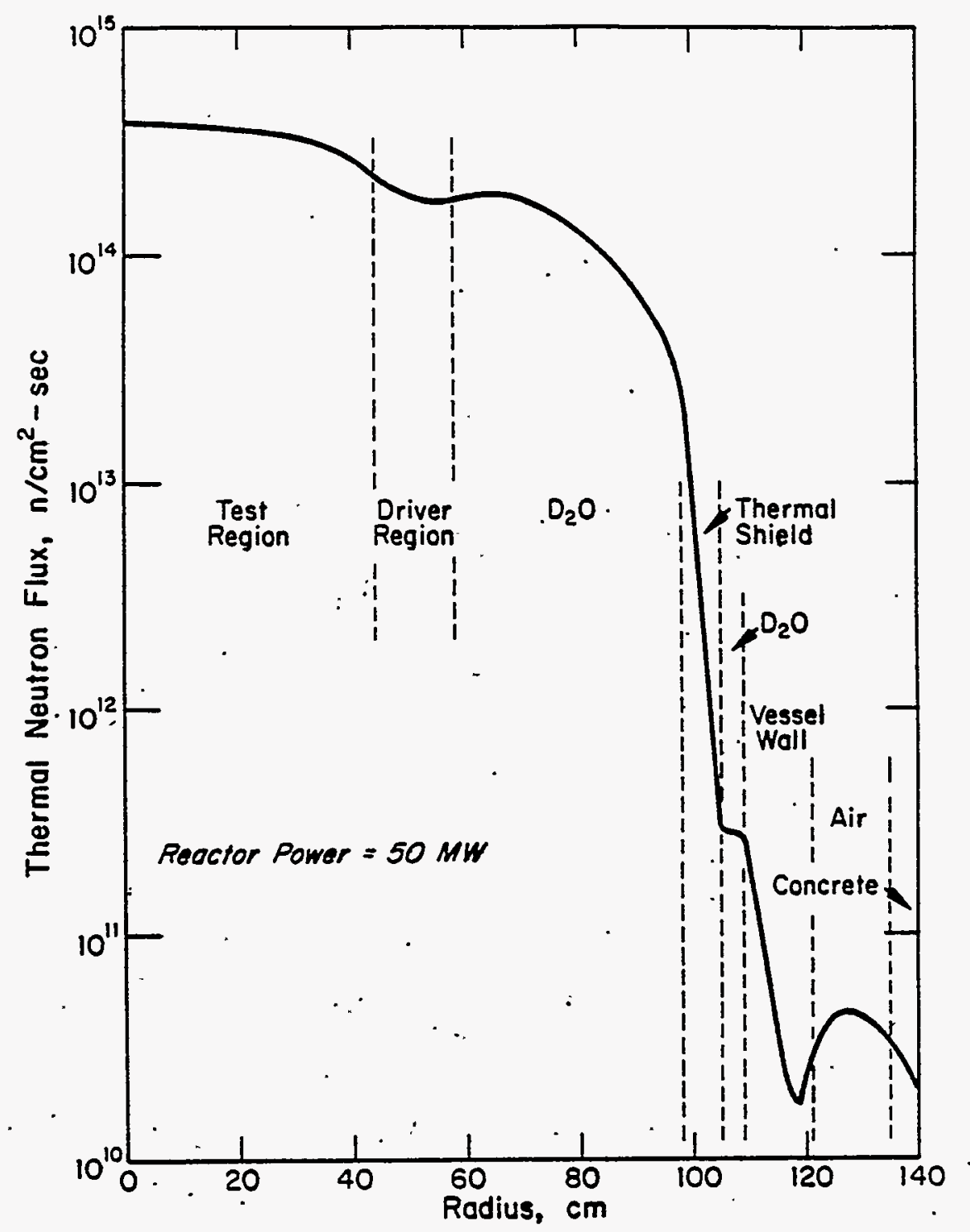

FIGURE 5. Radial Profile of Thermal Neutron Flux 


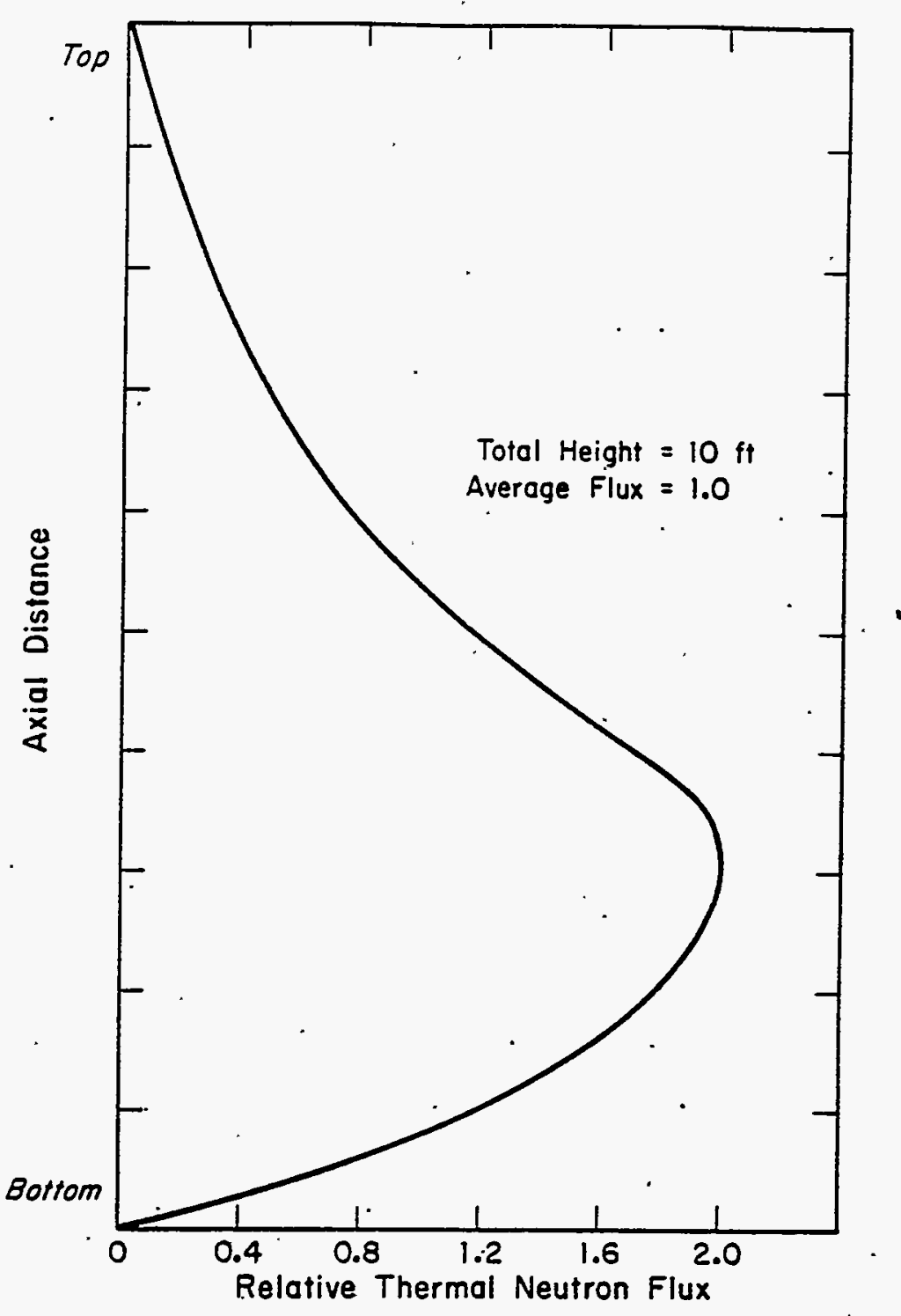

FIGURE 6. Axial Distribution of Thermal Neutron Flux $?$ 
The content of each radioactive nuclide relative to the initial content of its precursor was calculated from the standard expression,

$$
\begin{aligned}
& \frac{N_{2}}{\left(N_{1}\right)_{t=0}}=\frac{\alpha e^{-\alpha t}}{\beta}\left(1-e^{-\beta t}\right) e^{-\lambda_{2} T} \\
& \text { where } \alpha=\phi \sigma_{1} \\
& \beta=\lambda_{2}+\phi\left(\sigma_{2}-\sigma_{1}\right) \\
& t=\text { irradiation time } \\
& T=\text { decay time after shutdown } \\
& \text { Nuclear data are given in Table } 4 .
\end{aligned}
$$

\begin{tabular}{|c|c|c|c|c|c|}
\hline & & & & & \\
\hline Nane & $2200 \mathrm{~m} / \mathrm{sec} \sigma_{a}$, barns & $T \frac{1}{2}, y x$ & $\lambda, 86 e^{-1}$ & Dame & $2200 \mathrm{~m} / \mathrm{sec} \sigma_{\alpha}$, barns \\
\hline${ }^{55} \mathrm{Fe}$ & 0 & 2.7 & $8.1 \times 10^{-9}$ & ${ }^{54} \mathrm{Fe}$ & 2.3 \\
\hline${ }^{60} \mathrm{Co}$ & 2 & 5.3 & $4.2 \times 10^{-9}$ & ${ }^{39} \mathrm{Co}$ & 37 \\
\hline${ }^{6} \mathrm{Ni}$ & 23 & 100 & $2.2 \times 10^{-20}$ & ${ }^{62} \mathrm{Ni}$ & 14.2 \\
\hline
\end{tabular}

TABLE 4

Nuclear Data for Induced Activity

Radioactive Nuclida

The irradiation time used, 841 days, corresponds to the total period of HWCTR power operation. The activities were decayed from December 1964 to July 1975 (a period of 10 years and 7 months).

The equation for the ratio of the radioactive nuclide to its precursor was solved one time for each nuclide pair at a neutron flux of $10^{1.2} \mathrm{n} / \mathrm{cm}^{2}-\mathrm{sec}$. Relative contents in any reactor system component are proportional to those results multiplied by the ratio of the flux in that component to the $10^{12}$ flux.

304 stainless steel has the following nominal composition:

Element

Content, wt \%

$\because$

$\mathrm{Cr}$

19.0

$\mathrm{Mn}$

1.0

$\mathrm{Fe}$

70.9

Co

0.1

$\mathrm{Ni}$.

9.0 
The iron and nickel contents of any batch of stainless steel are carefully controlled and differ from the nominal fraction by $\pm 10 \%$ or less; e.g., nickel comprises 8 to $10 \%$ of any batch of 304 stainless steel. However, ${ }^{59} \mathrm{Co}$ is an impurity and has no controlled lower limit. The ${ }^{59} \mathrm{Co}$ content of several samples of stainless steel analyzed at the Savannah River Laboratory (SRL) several years ago varied from 50 to $1100 \mathrm{ppm}$. A value of $1000 \mathrm{ppm}(0.1 \%)$ was used throughout this evaluation.

Carbon steel contains only trace amounts of nickel and is comprised of about $99 \% \mathrm{Fe}$. The ${ }^{59} \mathrm{Co}$ content was assumed to be 1000 ppm.

The induced activity in a gram of stainless steel was cal-. culated from the data given in Table 5.

TABLE 5

Specific Activities in Stainless Steel

\begin{tabular}{|c|c|c|c|c|c|c|}
\hline $\begin{array}{l}\text { Radioactive } \\
\text { Nuclide }\end{array}$ & $\begin{array}{l}\text { Precursor } \\
\text { Atom Eraction }\end{array}$ & $\begin{array}{l}\text { Fraction of } \\
\text { Element in } 3 S\end{array}$ & $N_{2} / N_{1}^{a}$ & \multicolumn{3}{|c|}{ Activity Content } \\
\hline${ }^{55} \mathrm{Fe}$ & 0.058 & 0.71 & $0.83 \times 10^{-5}$ & 2410 & $0.82 \times 10^{-3}$ & 49 \\
\hline${ }^{60} \mathrm{Co}$ & 1.0 & 0.001 & $0.58 \times 10^{-3}$ & 1130 & $0.66 \times 10^{-3}$ & 40 \\
\hline${ }^{6}{ }^{3} \mathrm{Ni}$ & 0.036 & 0.09 & $0.95 \times 10^{-3}$ & 57 & $0.18 \times 10^{-3}$ & 11 \\
\hline & & & & otal & $1.66 \times 10^{-3}$ & \\
\hline
\end{tabular}

a. For theiral neutron flux of $10^{12} \mathrm{n} / \mathrm{cm}^{2}-\mathrm{sec}$, an irradiation time of 841 days, and a decay time of 101 years.

\section{Radioactivity of Major Components}

The residual activities of four major reactor components are given in Table 6. All components are made of stainless steel except for the reactor vessel, which is made of carbon. steel with a thin (0.25 inch) stainless steel liner.

The thermal shield and monitor pin plate contain over $90 \%$ of all activity remaining at the HWCTR site.

Simple decay of the reactor components will result in significant reductions in the ${ }^{55} \mathrm{Fe}$ and ${ }^{5} \mathrm{Co}$ activities over 20 to 30 years (Figure 7). However the ${ }^{6}{ }^{3} \mathrm{Ni}$ activity (100-year half-life) persists for a much longer period. The effects of postulated ${ }^{3} \mathrm{Ni}$ releases are evaluated (Consequence Analysis, page 62 ). 
TABLE 6

- Activity of Reactor Components

\section{Therma! Shield \\ Monitor Pin Plate \\ Reactor Vessel \\ Control Rods}

\begin{tabular}{rrrr} 
Activity, $C_{i}{ }^{a}$ & & \\
\hline${ }^{55_{E e}} \cdot$ & ${ }^{60} \mathrm{Co}^{b}$ & ${ }^{6}{ }^{3} \mathrm{Ni}$ & \multicolumn{1}{c}{ Total } \\
10,800 & 8800 & 2400 & 22,000 \\
$390 \cdot$ & 320 & 90 & 800 \\
380 & 230 & 10 & 620 \\
100 & $\frac{80}{9430}$ & $\frac{20}{2520}$ & $\frac{200}{23,620}$
\end{tabular}

a. July 1,1975 .

b. From the 1000 ppm ${ }^{59} \mathrm{Co}$ impurity assumed in steels.

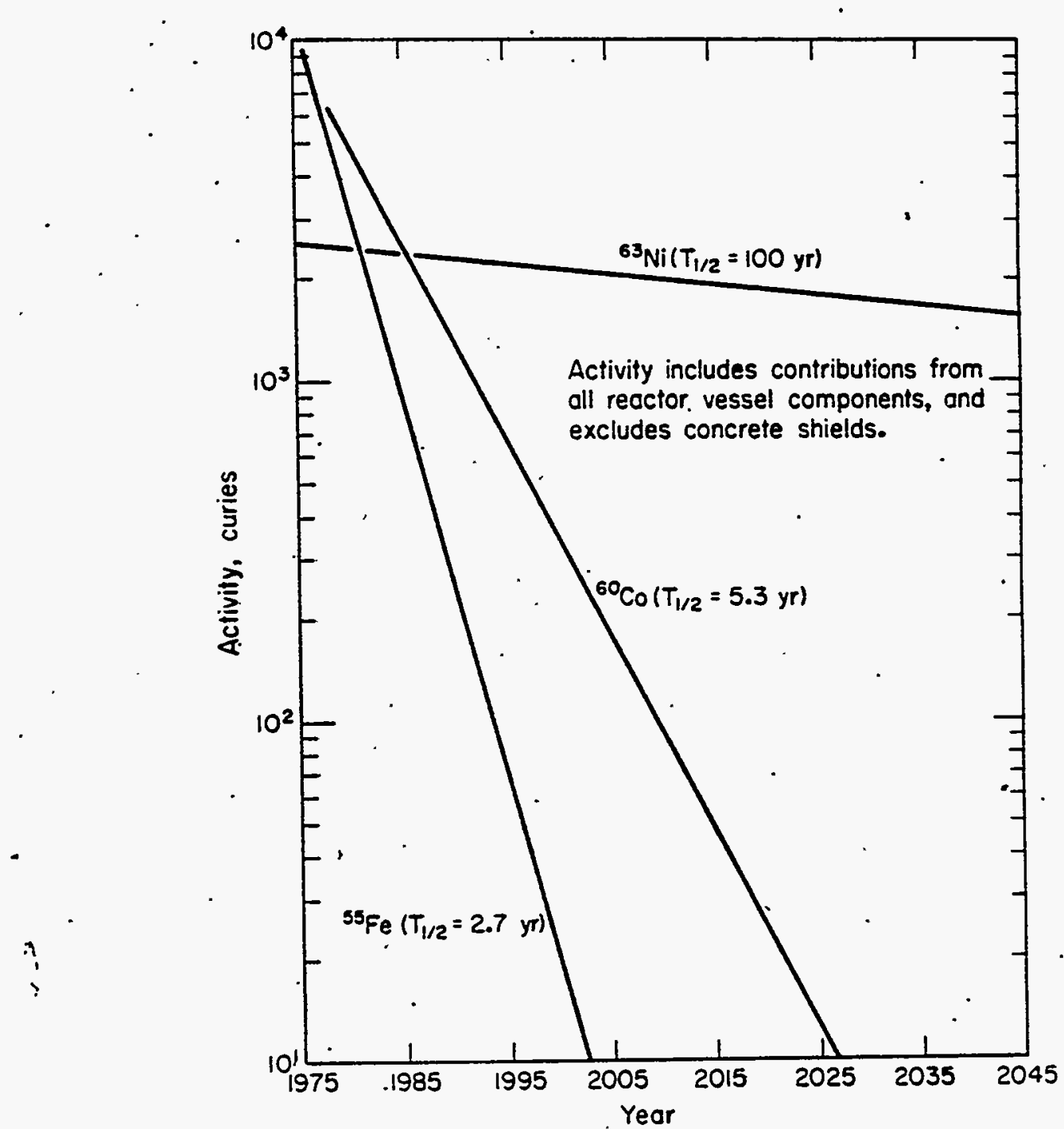

FIGURE 7. Activity Decay of Reactor Vessel Components 
The highest specific activity in the system is found at the inside surface of the thermal shield, about $3 \mathrm{ft}$ above the monitor pin plate. The activity there is $1.8 \times 10^{-2} \mathrm{Ci} / \mathrm{g}$ of stainless steel, including all three radioactive nuclides. The axial average over the inner surface is one-half that value, or $0.9 \times 10^{-2} \mathrm{Ci} / \mathrm{g}$ of stainless steel. The average value for the entire thermal .shield is $0.18 \times 10^{-2} \mathrm{Ci} / \mathrm{g}$ of stainless steel. The ${ }^{6}{ }^{3} \mathrm{Ni}$ activity is $11 \%$ of the above activities.

\section{Induced Activity in Concrete}

The induced activity in concrete shields must be considered in any proposal for dismantling the HWCTR facilities. ${ }^{60} \mathrm{Co}$ is the radionuclide of most importance, originating from ${ }^{59} \mathrm{Co}$ that was present in steel shot or iron reinforcing rods, and also was present as a natural impurity of ordinary concrete. Three shield regions are of interest: the lower axial shield, the barytesconcrete annular shield around the lower portion of the vessel, and the biological shielding walls.

- Lower axial shield - a right circular cylinder, $3 \frac{\text { ft thick }}{2}$ and about $5 \mathrm{ft}$ in diameter. It consists of $90 \%$ steel shot by weight and $10 \%$ concrete. The total ${ }^{\circ}{ }^{\circ} \mathrm{Co}$ activity of the shield is about $10 \mathrm{Ci}$, confined to the upper few inches of the shield nearest the reactor. Removal of the shield is necessary if the site were dismantled in the next 20-30 years.

- Barytes shield - an annular ring of concrete surrounding and extending above the axial shield. The iron content is $13 \%$ by weight. The total ${ }^{60} \mathrm{Co}$ activity of the shield is about $10 \mathrm{Ci}$. Removal of the shield is necessary if the site were. dismantled in the next 20-30 years.

- Other concrete shielding - the remainder of the concrete shields is composed of ordinary concrete. No specifications exist for the ${ }^{59} \mathrm{Co}$ content of ordinary concrete. To obtain an estimate of the ${ }^{59} \mathrm{Co}^{\circ}$ content, two samples were obtained from the shield wall on the $37-f t$ elevation and were analyzed by neutron activation and by atomic absorption. Irradiated -concrete is not accessible.<smiles>C[Tl]</smiles>

Neutron Activation

Wet Chemistry (atomic absorption)

\section{$\frac{{ }^{9} \text { Co Content, ppm }}{\text { Sample 1. Sample } 2}$}

10

140

44

130 . 
The spread in results is not unexpected, considering the limited number of samples and the sample size. A value of $100 \mathrm{ppm}$ was used in estimating the ${ }^{60} \mathrm{Co}$ activity in concrete near the reactor vessel at $400 \mathrm{pCi} / \mathrm{g}$. The limit for ${ }^{80} \mathrm{Co}$ in concrete specified for the Elk River decommissioning was $0.04 \mathrm{pCi} / \mathrm{g}$. At least $3 \mathrm{ft}$ of concrete would have to be removed from inside the vessel cavity to achieve the Elk River limit. The reinforcing rods in the concrete would also have to be removed.

A better estimate of ${ }^{60} \mathrm{Co}$ activity in the concrete could be made by core drilling through the shield to the reactor vessel wall and analyzing the core material. If a dismantling plan is to be developed in further detail, these data would be useful in determining more precisely the concrete removal that would be necessary. The total volume would still be uncertain until the vessel cavity was exposed and some material actually removed. The $0.04 \mathrm{pCi} / \mathrm{g}$ value is a very stringent requirement. A severe cost overrun was experienced in the concrete removal costs in the E1k River dismantlement . $(\$ 350,000$ estimated versus $\$ 1.2$ million spent).

\section{Reactor Vessel Measurements.}

Direct radiation measurements on the reactor vessel were' obtained to estinäte personnel exposure rate and to confirm calculations of induced radioactivity in the reactor vessel. Measurements were taken in available openings through the biologicaI stilerd including two power level-sleeves and a neutron

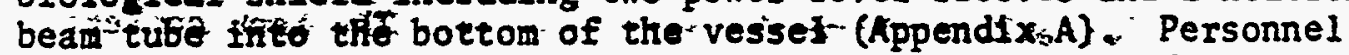
dose rates ate estimated to be $2-3$. R/hF-at a distance of $2 \mathrm{ft}$ from the reactor vessel. Open process water lines near the reactor would increase dose rates.by a factor of $100_{2}$ Measurements through a neutron bean tube indicated $140 \mathrm{R} / \mathrm{hr}$ inside the bottori of the- reactor vessel at - the bottom of the nonitor pin

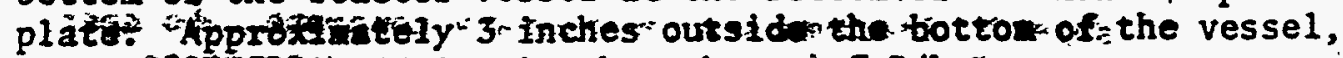
the ragateng intorisity in the tube was $7: R / h r:$

The calculated specific activities of the thermal shield and reactor vessel (Table 6) were used to calculate the radiation levels at the three locations where data were obtained. The expression used in the conversion was for an infinite-slab source with slab shields located between the source and the de-

$\because$ tector. Source terms were expressed in ${ }^{60} \mathrm{Co}$ disintegrations/cc; flux terms at the detector were converted to $\mathrm{mR} / \mathrm{hr}$. The results are presented in Table 7.

Radiation levels outside the vessel are reduced by a factor of $10^{3}$ because of the shielding afforded by the vesse 1 and other intermediate materials. The relatively good agreement between 
calculated and measured results supports the neutron fluence $(\phi t)$ and the ${ }^{59} \mathrm{Co}$ content of the thermal shield assumed in the calculations.

TABLE $\cdot 7$

Radiation from the Reactor Vessel

\begin{tabular}{lll} 
& \multicolumn{2}{l}{ Radiation Levels, mR/hr } \\
\cline { 2 - 3 } Location & Calculated & Measured \\
SLV-1 & 490 & 500 \\
SLV-4 & 120 & 210 \\
Beam tubes (inside & 410,000 & 140,000
\end{tabular}

reactor vessel)

Radiation in Work Areas

Personnel radiation dose rates for general work related to disassembly and removal of equipment will be low with the exception of work associated with the reactor vessel. Exposure rates below zero level will average only 2-3 mR/hr and will be less than $1 \mathrm{mR} / \mathrm{hr}$ on zero level until the reactor tank top is removed or the reactor tank is exposed. - Although available radiation data. indicate dose rates of $2-3 \mathrm{R} / \mathrm{hr} 2 \mathrm{ft}$ from the side of the reactor tank, it must be recognized that opening process water lines, removing the tank top or otherwise exposing the inside of the reactor- Will cause large increase in exposure dose rates.

Protective clothing required for work on zero level will be-minimal (gloves, shoe covers, lab coats) except for work associated with the reactor tank and associated process water and off-gas piping: Initial line breaks on process lines will require assault masks or fresh air masks if burning is necessary. Work below zero level will, require coveralls, gloves, and shoe covers. Fresh air masks will be required for burning or welding on contaminated equipment. and may be required in some instances for opening process water lines for tritium protection. Survey record ind feate that.tritium-contaminated water has spilled

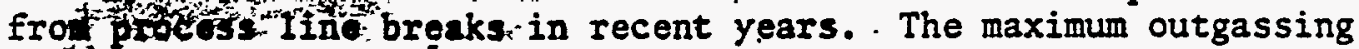
recorded is $40 \times 10^{-5} \mathrm{\mu Ci} / \mathrm{cc}$ of air during breaks in 1972 .

2

The dome and some equipment in and above the zero level, including the crane, probably. can be excessed for unrestricted use with. a minimum of decontamination. This does not include process water, off-gas, and other equipment used in direct contact with reactor fuel, the tank, or the fuel storage basin. 
Release for unrestricted use would require a detailed survey at the time the equipment is removed.

\section{Radioactivity Guidelines}

For each of the three decommissioning alternatives, activity guidelines are needed for direct personnel exposure, for indirect exposure via activity transport from the site, and for dispositions of materials removed from the HWCTR site. Documents cited below were reviewed to determine appropriate guidelines even though some of the regulations do not specifically apply to the HWCTR program. cited:

The following abbreviations will be used i.r the regulations

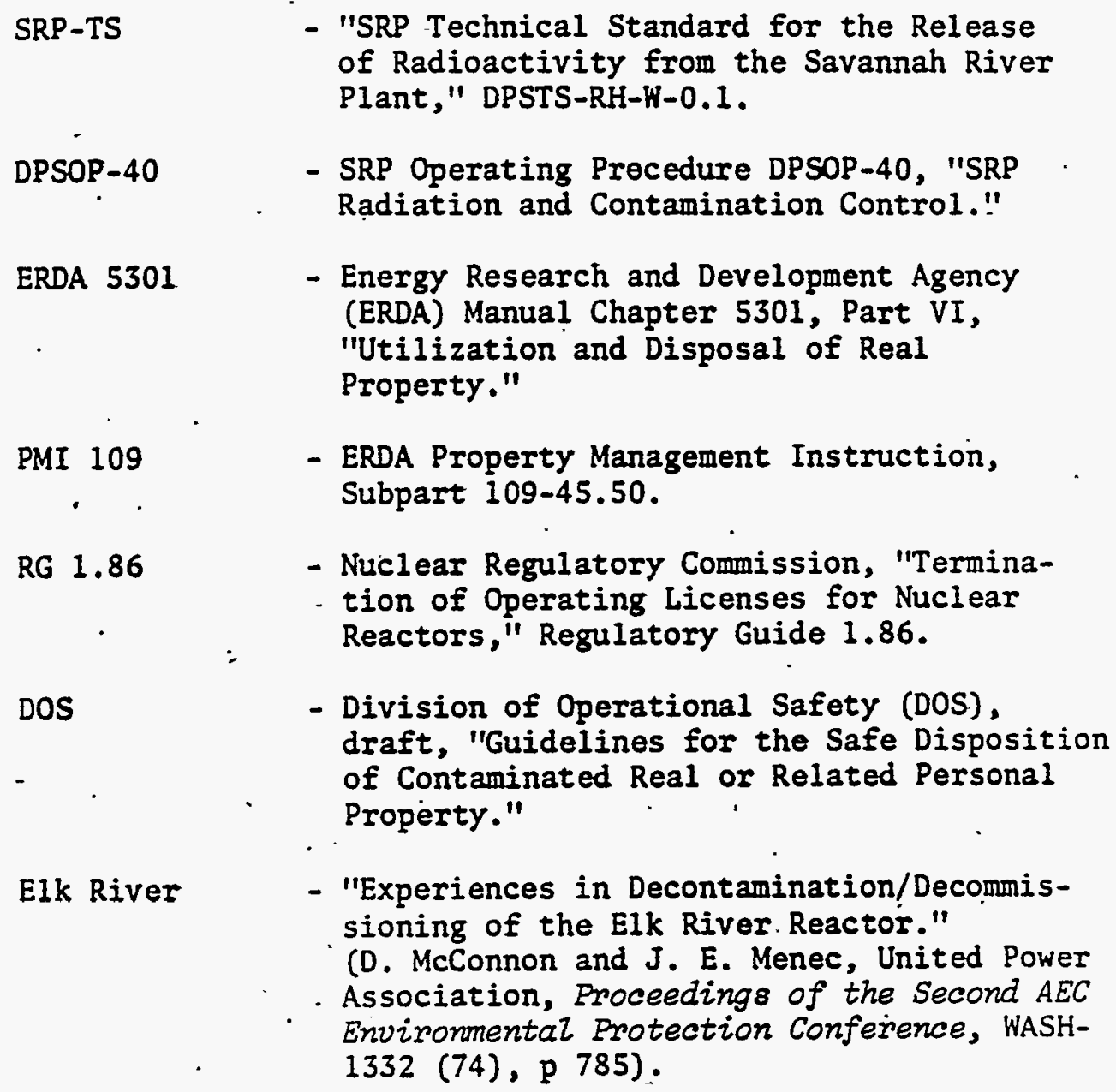

Specific values used in this decommissioning plan are given in Table 8 . 
TABLE 8

Radiation and Contamination Guidelines

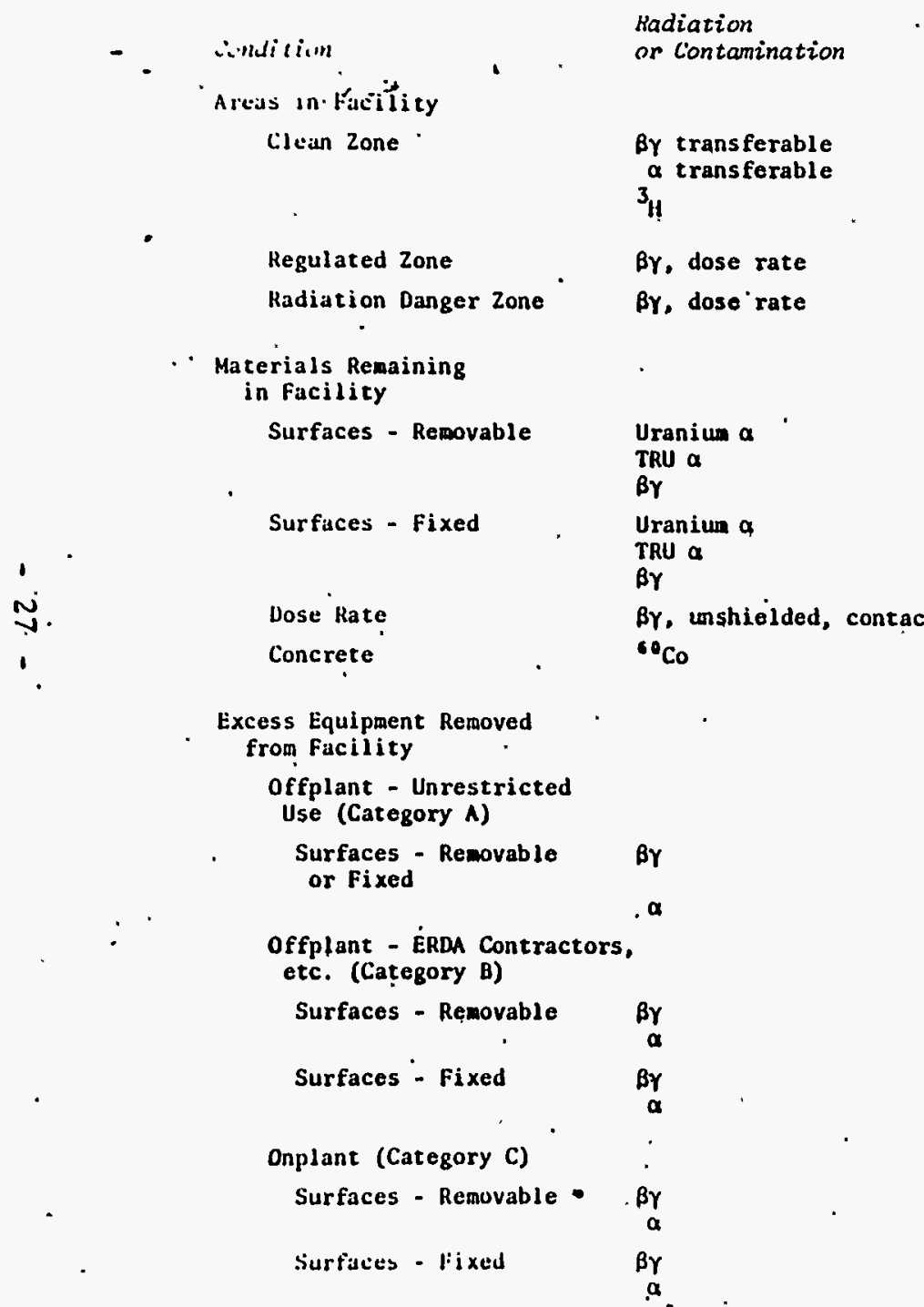

arideline Limit

Source

Applicable to

Guidezine Limit

of Limit

Confinement

$\begin{array}{lll}80 \mathrm{~d} / \mathrm{m} & \text { DPSOP-40 } & X \\ 10 \mathrm{~d} / \mathrm{m} & \text { DPSOP-40 } & X \\ 50 \mathrm{c} / \mathrm{m} \text { above } & \text { DPSOP-40 } & X \\ \text { background } & & \\ 300 \mathrm{mrad}-50 \mathrm{mrem} / \mathrm{hr} & \text { DPSOP-40 } & X \\ 300 \mathrm{mrad}-50 \mathrm{mrem} / \mathrm{hr} & \text { DPSOP-40 } & X\end{array}$

$>300 \mathrm{mrad}-50 \mathrm{mrem} / \mathrm{hr}$ DPSOP-40 $x$

$\begin{aligned} 1000 \mathrm{dpm} / 100 \mathrm{~cm}^{2} & \text { RG } 1.86 \\ 20 \mathrm{dpm} / 100 \mathrm{~cm}^{2} & \text { RG } 1.86 \\ 1000 \mathrm{dpm} / 100 \mathrm{~cm}^{2} & \text { RG } 1.86 \\ 5000 \mathrm{dpw} / 100 \mathrm{~cm}^{2} & \text { RG } 1.86 \\ 100 \mathrm{dpm} / 100 \mathrm{~cm}^{2} & \text { RG } 1.86 \\ 5000 \mathrm{dpm} / 100 \mathrm{~cm}^{2} & \text { RG } 1.86 \\ 0.3 \mathrm{mrem} / \mathrm{hr} & \text { PMI } 109 \\ 0.04 \mathrm{pCi} / \mathrm{g} & \text { EIk River }\end{aligned}$

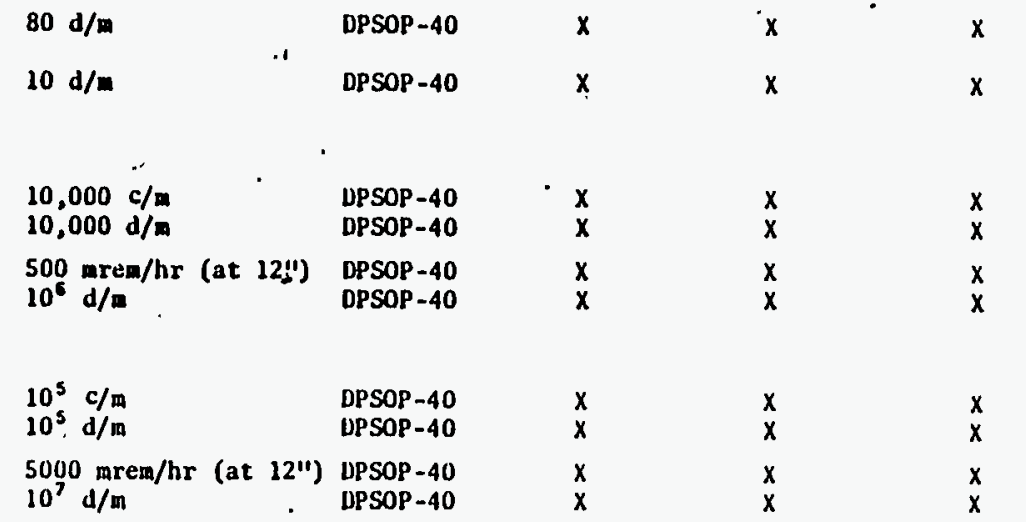




\section{Dismantlement}

For dismantlement, all equipment and structural materials containing or contaminated. with radioactivity above guidelines are to be removed. The guidelines depend on whether or not the property will be reused for ERDA-controlled activities or released for uncontrolled public use (DOS). The proposed DOS guidelines include both RG 1.86 contamination limits, and limits for contaminated materials and equipment (PMI 109). Case-by-case review of decontamination criteria is also provided. A combination of the most suitable guidelines from the various sources is recommended for dismantlement. Adherence to these guidelines should permit release of the HWCTR site for uncontrolled use. Guideline limits were selected for contamination levels on materials remaining in the facility (RG 1.86, DOS); for dose rates from these materials (PMI 109), and for disposition limits for materials removed from the facility (DPSOP-40). In addition, $0.04 \mathrm{pCi} / \mathrm{g}$ of ${ }^{60} \mathrm{Co}$ in concrete is the upper limit for estimating the amounts of concrete to be removed. Elk River dismantlement used this limit for burial of concrete rubble in noncontaminated landfills. The proposed DOS guidelines also include the requirements for monitoring given in PMI 109. The ability to detect levels of beta-gamma radiation to $10 \mu \mathrm{rad} / \mathrm{hr}$ through not more than $7 \mathrm{mg} / \mathrm{cm}^{2}$ absorber at $1 \mathrm{~cm}$ from the surface is required. Alpha detection capabilities are required to be $1000 \mathrm{dpm} / 100 \mathrm{~cm}^{2}$ for nonplutonium alpha, and $100 \mathrm{dpm} / 100 \mathrm{~cm}^{2}$ for plutonium alpha.

\section{Entombment}

For entombment, only some of the contaminated equipment external to the biological shield would be removed from the facility. The remaining radioactive or contaminated components would be-sealed within a structure that would meet the criteria of prevention of access to the facility (DOS) and structural integrity over the period of time in which significant quantities of radioactivity remain with the material in the entombment (RG 1.86): A set of acceptable contamination levels are given in RG 1.86 (also proposed by DOS), and in the case of entombment - these are defined as "significant quantities of radioactivity." Most of the radioactivity associated with the HWCTR is activation products induced throughout steel or concrete; therefore, the

$\because$ RG 1.86 standards (designed for decontamination criteria) need

$\therefore$ to be supplemented. A dose rate limit of $0.3 \mathrm{mrad} / \mathrm{hr}$ (PMI 109) was selected for exposure from equipment. 
These guidelines are considered consistent with the proposed ERDA requirement for entombment: "Radiological safety criteria for the entombment of radioactivity will be developed on a case-by-case review and must be based on a hazards evaluation of the proposed action. These criteria must be approved by the Director, Division of Operational Safety (DOS)."

\section{Protective Confinement}

Protective confinement assumes ERDA control of the HWCTR site and the land containing ground-water migration pathways from the site to Upper Three Runs Creek. SRP regulations (DPSOP40) that define clean, regulated and radiation danger zones would be applicable and adequate to prevent accidental exposure of personnel. The regulations also cover the disposition of contaminated equipment removed from the HWCTR site. Periodic surveillance would be required, and results should be well documented.

The present SRP Technical Standard for offsite effects of the release of radioactivity from SRP was selected as a conservative criteria to analyze the effects from radioactivity reaching the environs after HWCTR decommissioning. The primary reason for using this low dose is that decommissioning a radioactive facility involves securing the activity such that public effects are minimal. In fact, only a pessimistic combination of highly unlikely conditions without normal corrective action will initiate transport of the residual activity offsite. Therefore logic dictates that this activity transport once initiated from HHCTR activity will continue under the ground rules applied (Consequence Analysis, page 62).

The radionuclides remaining in the HWCTR in significant quantities are ${ }^{60} \mathrm{Co}$ (half-life $5.3 \mathrm{yr}$ ) and ${ }^{63} \mathrm{Ni}$ (half-life 100 $y r)$. The properties of these nuclides and the estimated quantities are given in Tables 4 and 6 . The. concentrations in water that would result in the limiting doses were calculated for these two nuclides and for ${ }^{239} \mathrm{Pu}$, which is present in the HWCTR but in very low quantities. If releases from the HitCTR reach an aquatic environment such as Upper Three Runs Creek or the Savannah River, radionuclidic concentrations in the food chain must also be considered. If both ${ }^{6}{ }^{3} \mathrm{Ni}$ and ${ }^{2}{ }^{39} \mathrm{Pu}$ are present in the drinking water, the limiting concentrations should be adjusted proportionally since they both contribute dose to bone. Calculated concentrations for isotopes of interest are shown in Table 9.

'The derivation of the various concentration limits is given in Appendix B. 
TABLE 9

Concentrations for $30 \mathrm{mRem} / \mathrm{yr}, \mu \mathrm{Ci} / \mathrm{cc}$

$\begin{array}{llll}\text { Nuclide Critical Organ } & \text { Drinking Water } & \begin{array}{l}\text { Drinking } \\ \text { and Eating }\end{array} \\ { }^{2{ }^{9} \mathrm{Pu}} & \text { Bone } & 6.2 \times 10^{-8} & 4.4 \times 10^{-8} \\ { }^{60} \mathrm{Co} & \begin{array}{l}\text { GI Tract (Large } \\ \text { Lower Intestine) }\end{array} & 1.1 \times 10^{-6} & .7 .4 \times 10^{-7} \\ { }^{63} \mathrm{Ni} & \text { Bone } & 4.9 \times 10^{-7} & 1.3 \times 10^{-7}\end{array}$

Other possible limits considered were from ERDA Manual Chapter 0524, "Standards for Radiation Protaction and 10 CFR 100, "Reactor Site Criteria." The former consins effects from normal releases; limits in the latter regulation thain to reactor accidents. All limits are compared in Tate 10 including the recent radiation dose standards for the uranium fuel cycle proposed by the Environmental Protection Agency (EPA).

The SRP Technical Standards were selected for'the following reasons:

- Present SRP operations are conducted within these limits. Predicted releases from an inactive facility should be lower even for consequences that result from unexpected conditions many years in the future.

- It is probable that the ERDA 0524 guides will be lowered in the future, particularly if the EPA's proposals are accepted.

- The 10 CFR 100 guides pertain to major accidents that have a potential for large releases of radioactivity. No such situation exists in HWCTR.

- Other decomissioning operations also used standards that apply to normal operations (10 CFR 20 for Hallam, Bonus, etc); Elk River used Appendix I to 10 CFR 50. 
TABLE 10

Dose Limit Comparisons - Public Zone

\begin{tabular}{|c|c|c|c|c|c|}
\hline $\begin{array}{l}\text { Ege of } \\
\text { Exosure }\end{array}$ & $\begin{array}{l}\text { SRP Tech Std, } \\
\text { mem/yr } \\
\text { Individual Max }\end{array}$ & $\begin{array}{l}\text { ERDAM OS } \\
\text { mrem/yr } \\
\text { Ind Hax }\end{array}$ & POP AVG & $\begin{array}{l}\text { ERA Proposal, } \\
\text { U Euel Cycle, } \\
\text { mrem/yr }\end{array}$ & $\begin{array}{l}10 \text { CER } 100^{\circ}, \\
\text { rrem }\end{array}$ \\
\hline Whole body & 10 & 500 & 170 & 25 & 25,000 \\
\hline Gonads & 10 & 500 & 170 & 25 & - \\
\hline Bone marrow & 10 & 500 & 170 & 25 & - \\
\hline Gastrointestinal tract & 30 & 1500 & 500 & 25 & - \\
\hline Bone & 30 & 1500 & 500 & 25 & - \\
\hline Thyroid & 30. & 1500 & 500 & 75 & 300,000 \\
\hline All other organs & 30 & 1500 & 500 & 25 & - \\
\hline
\end{tabular}

\section{CRITERIA}

- Criteria were developed to weigh the alternatives of decommissioning HWCTR. The criteria include special factors that may be unique for the Savannah River. Plant site but in general reflect guidelines proposed for ERDA facilities. The criteria are radiation impact, cost, land area commitment, timing, and aesthetics.

Radiation Impact

The radiation impact of decommissioning HWCTR consists of several elements. In the completion of decommissioning, the work force will be exposed to an occupational dose. Estimates of the dose are made from radiation surveys and Construction Division estimates. After decommissioning, two potential paths for additional dose to the public exist via exposure to direct. radiation from the vessel or ingestion of water contaminated by the vessel. The Safety Analysis section includes the evaluations of the likelihood and consequences of radiation from HWCTR activity for a!l alternatives. 
Cost

The cost elements in each alternative are the capital cost of the decommissioning step and the operating cost for surveillance, maintenance, and monitoring. Lowest cost alternatives that protect the public should be favored because tax money will be spent for decommissioning.

\section{Land Area Commitment}

The land area associated with each alternative is estimated from current site maps. The acreage in $U$ area is already a small portion of the SRP site, but it also may be required to retain the water rights between $U$ area and Upper Three Runs Creek for all cases except dismanting the reactor. The importance of 1 and depends heavily on the long-term ERDA plans for the site (currently undefined).

\section{Timing}

This factor is a judgment of what decommissioning action (and when) is in the best interest of the taxpayer. The effort will be simplified by ${ }^{60} \mathrm{Co}$ decay in 35-70 years, and there is no immediate incentive to act as long as the activity is secure in the interim. On the SRP site, such security is essentially guaranteed. However, there is always some merit in finally resolving a decomissioning step rather than continuing studies under changing rules.

\section{Aesthetics}

Although less significant than other criteria, some of the public prefer an approach that restores the land to preconstruction state. The emphasis of aesthetics (as with land area) would differ for a more visible reactor site rather than an isolated region as. at the SRP site. Industrial reactor sites or sites containing multiple reactors should be weighted differently on aesthétics than a site reusable for industrial applications.. 


\section{ALTERNATIVES}

Three-alternatives for decommissioning HWCTR were evaluated in developing this plan:

\section{Altemative \\ Dismaritlement}

Entombment

Protective Confinement

\section{objective}

Restore the U site to a condition suitable for release to the general public. Relocate HWCTR radioactivity to the site burial ground.

Secure the activity remaining in the HWCTR facility so that release to the environment is extremely improbable until decay renders it harmless.

Confine activity at the HWCTR site in dry storage for the forseeable future while decay proceeds.

Alternatives selected for decommissioning HWCTR were in part derived from a review of decommissioning action of other similar reactors. As shown in Table 11 , only one reactor (Elk River) has been dismantled (1973) both as an AEC demonstration and to meet the political requirement of no residual activity in the state of Minnesota. Parts of the reactor are now in commercial burial grounds in Illinois, Kentucky, and Washington. Four reactors have been entombed in varying degrees; Bonus entombment is the most similar to the HWCTR case studies. Six* reactors are now decommissioned in a state similar to protective confinement. In ali of these cases (including Elk River), the utility owns the land site and in some cases is operating other reactors nearby.

Within each broad alternative, options were evaluated as separable cost items for consideration in the scope of work for each case. Different methods of meeting the objective are also recorded without feasibility or costs for future consideration as part of the discussion of alternatives.

Key features in alternatives for decommissioning HWCTR are compared in Table 12 .

* Ṕroposed for Peach Bottom 1 subject to NRC approval. 
TABLE 11

IINCTR

A. Disnantled/Land Released

Elk River

B. Entombrient - Release of Facility

Hallam

Sodium

$240^{\circ}$

75

$1963-1964$

$--$

Entembonent of Nuclear Section -

趈

Bonus

Piqua

AF.YEC

BHR

$5 n$

16.5

1964-1968

1970

10

OAR

$11.4 \quad 1964-1966$

1968

1965-1970

1971

$215 \quad 5 \times 10^{4}(1969)$

$3 \quad 10^{5}$ (at shut-

down)

0.5

C. ibthballed

Saxton

CVTR

Peach Bottom -

Pathfinuer**

EBR - 1 .

remi

$\begin{array}{lcc}\text { PUR } & 28 & \\ \text { PHILR } & 65 & 17 \\ \text { HTGR } & 115 & 40 \\ \text { BUR } & 190 & 58.5 \\ \text { Sodium } & -. & \\ \text { Sodium } & 200\end{array}$

\begin{tabular}{|c|c|c|}
\hline 3 & $1962-1972$ & - \\
\hline 17 & $1963-1967$ & 1967 \\
\hline 40 & $1966-1972$ & Now underway \\
\hline 58.5 & $1964-1967$ & 1968 \\
\hline .15 & $1951-1964$ & -- \\
\hline - & $\begin{array}{l}1965-1966 \\
1970-1972\end{array}$ & $\begin{array}{c}1973- \\
1974\end{array}$ \\
\hline
\end{tabular}

-- $10^{5}$ (at shut- $\begin{gathered}\text { down) } \\ \text {-- }\end{gathered}$

-- - -

-. $10^{6}(6$ mos. decay $)$

-- .

$\begin{array}{lll}- & -- & --\end{array}$

*Support facilities used for storage, for support facilities to other reactors on site, etc.

* Converted to oil-fired station.

***<5 without fuel reprocessing. 
TABLE 12

- Comparison of Alternatives

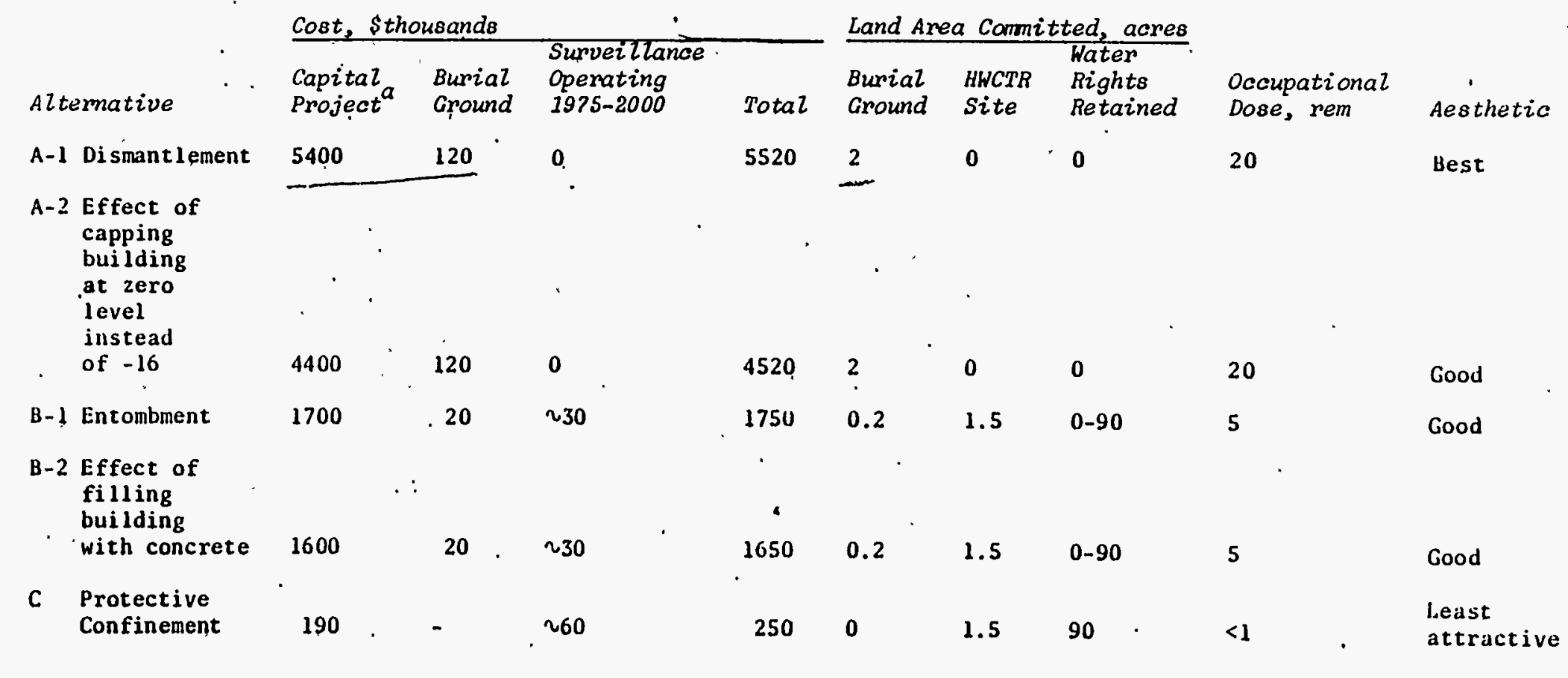

a. Engineering Department Current Assessment of Cost for Evaluation, not Budget Quality and based on this schedule:

\begin{tabular}{|c|c|c|c|}
\hline \multirow[b]{2}{*}{ Alternative } & \multirow[b]{2}{*}{ Authoriz } & \multicolumn{2}{|c|}{ Construction } \\
\hline & & Start & Complet \\
\hline $\begin{array}{l}A \\
\text { D }\end{array}$ & $1 / 78$ & $8 / 78$ & $\begin{array}{r}7 / 79 \\
10 / 78\end{array}$ \\
\hline $\begin{array}{l}\text { B } \\
\text { C }\end{array}$ & $\begin{array}{l}1 / 78 \\
1 / 78\end{array}$ & $\begin{array}{l}3 / 78 \\
4 / 78\end{array}$ & $\begin{array}{r}10 / 78 \\
8 / 78\end{array}$ \\
\hline
\end{tabular}




\section{Dismantlement}

The objective of dismantlement is to remove all of the equipment with residual radioactivity above specified levels, so that the site could be released to the general public without restrictions. The residual radioactivity guidelines are discussed in Radioactivity Guidelines (Table 8). The practical implication of these guidelines is to require all of the equipment that was normally in contact with $\mathrm{D}_{2} \mathrm{O}$ be removed. About $1300 \mathrm{ft}^{3}$ of radioactive reinforced concrete around the reactor cavity, the lower axial shield, and portions of the spent fuel basin liner are to be removed. In Tables 13 and 14, equipment to be removed and buried is specified.

The containment dome (Figure 8 ) and other above-grade structure of buildings are to be dismantled and removed from the site with no credit for sale or reuse. The steel and concrete structure of the reactor building (Figures 9 and 10) is to be removed to a depth of about $16 \mathrm{ft}$ below grade, the remaining. building cavity backfilled and capped with a concrete pad at the . 16-ft depth, and the remaining cavity backfilled to grade level to clear the site for future construction.

The physical volume of. HWCTR equipment to be removed and buried is about 14,000 $\mathrm{ft}^{3}$. The estimated burial ground area required is 2 acres with normal burial practice, or about $1 \%$ of the total burial ground site. The cost of burying the equipment is estimated at $\$ 120,000$. About $3400 \mathrm{ft}^{3}$ of equipment, including the reactor vessel, would require burial in the fiigh level trenches (Table 13), and the balance in the low level trenches. About $100 \mathrm{ft}^{3}$ of equipment might require burial: in the alpha trenches.

TABLE 13

Dismantlement Alternative - Equipment to be Removed and Buried in High Level Trenches ${ }^{a}$

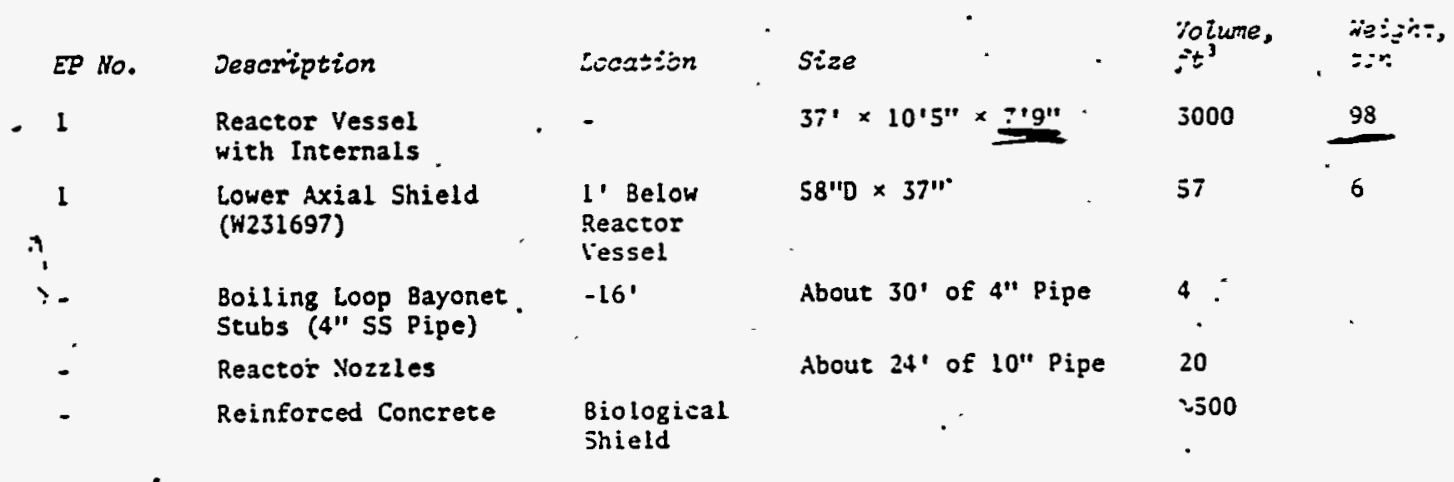

1. Category $B$ equipment, beta-gamma $\vdots 1$ gh level waste (Table 16). 
TABLE 14

Qismantlement Alternative - Equipment to be Removed and Buried in Low Level Trenchesa

EP No. Description Location Sizeb

$\begin{array}{llllll}\text { EP No. } & \text { Description } & \text { Location } & \text { Size } & \begin{array}{l}\text { Volime, } \\ f^{\prime} t^{\prime}\end{array} & \begin{array}{l}\text { Weigint, } \\ \text { lig }\end{array} \\ 41 & \text { Main Storage Tank } & -52^{\prime} & 20^{\prime} 6^{\prime \prime} \times 9^{\prime} \times 9^{\prime} & 1660 \\ 20.1 & \text { Steam Generator } & -16^{\prime},-37^{\prime} & 23^{\prime} 3^{\prime \prime} \times 6^{\prime} 1^{\prime \prime} \times 6^{\prime} 1^{\prime \prime} & 860 & 37,800 \\ 20.2 & \text { Stean Generator } & -16^{\prime},-37^{\prime} & -23^{\prime} 3^{\prime \prime} \times 6^{\prime} 1^{\prime \prime} \times 6^{\prime} 1^{\prime \prime} & 860^{\prime} & 37,800 \\ 21.1 & \begin{array}{l}\text { Main Pump } \\ \text { Without Motor }\end{array} & -16^{\prime} & 1^{\prime} 8^{\prime \prime} \times 7^{\prime} 6^{\prime \prime} \times 6^{\prime} 1^{\prime \prime} & 546 & \end{array}$

21:2 Main Pump

86

86.1

194

$42^{\circ}$

$\begin{array}{cc} & 86 \\ \cdots & 86.1 \\ & 194 \\ & 42\end{array}$

Gas Recompressor

Gas Recoupressor

ICL $^{d}$ Storage Tank

Makeup Pump Without

Motor

103

104

$\mathrm{SFB}^{6}$ Deionizer

SFB Filter

$-16^{\prime}$

$12 \cdot 811 \times 76^{\prime \prime} \times 6^{\prime} 1 " 10546$

186.1

LLG Pump Without

$$
-16^{\prime}
$$

$12 ' 8^{\prime \prime} \times 76^{\prime \prime} \times 6^{\prime} 1^{\prime \prime} 546$

$-52$

.-52

$-52$

$-52$

$-52^{\prime}$

-52,

$-16^{\prime}$

186.2.

Motor

53

LL Pump Without

Motor

101.1

101.2

51

47

92

180

195

193

45

191

Hold Tank

-16 '.

$-52^{\prime}$

-52 '

-52 '

SFB Cooler

Drain Tank

-52 :

$-37$

Collection Tank

Catch Pot

$-52$

ICL Seal Purap.

ICL Seal Puap.

$-52^{\prime}$

-52 '

ICL Afterfilter

$-371$

Main Afterfilter

$-37$

LL Purge Cooler

$-371$

$8^{\prime} 6^{\prime \prime} \times 5^{\prime} \times 4^{\prime} \quad 170$

$8^{\prime} 6^{\prime \prime} \times 5^{\prime} \times 4^{\prime} \quad 170$

$8^{\prime} \times 4^{\prime} \times 4^{\prime} \quad 128$

$7 \times 5.91 \times 210^{\prime \prime} \quad 113$

5'7' $\times 4^{\prime} 4^{\prime \prime} \times 4$ '4" $\cdot 105$

5'7' $\times 4^{\prime} 4^{\prime \prime} \times 4^{\prime} 4^{\prime \prime} \quad 105$

$7 ' 1$ " $\times 4$ '4" $\times 3$ '4" 102

$7^{\prime} 1^{\prime \prime} \times 4^{\prime} \times 4^{\prime \prime} \times 3^{\prime} 4^{\prime \prime} 102$

$11^{\prime} 8^{\prime \prime} \times 21^{\prime \prime} \times 21^{\prime \prime} \quad 36$

$13^{\prime} \times 26^{\prime \prime} \times 13^{\prime \prime} \quad 30$

$13^{\prime} \times 26^{\prime \prime} \times 13^{\prime \prime} \quad 30$

$4^{\prime} \times 32^{\prime \prime} \times 32^{\prime \prime} \quad 28$

5 '1" $\times 26^{\prime \prime} \times 26^{\prime \prime}$

$46^{\prime \prime} \times 30^{\prime \prime} \times 30^{\prime \prime} \quad 24$

$35^{\prime \prime} \times 29^{\prime \prime} \times 38^{\prime \prime} \quad 22$

$35^{\prime \prime} \times 29^{\prime \prime} \times 38$ " 22

$4^{\prime} \times 27^{\prime \prime} \times 21$.

3 '5' $\times 2$ ' $\times 2^{\text {r }}$

- 32 " $\times 23^{\prime \prime} \times 25^{\prime \prime}$

2800

2800

250

(continued) 
TABLE 14 (Continued)

\begin{tabular}{|c|c|c|c|c|c|}
\hline$\Xi \Xi$. & Jescription & Location & $s i z e^{b}$ & $\begin{array}{l}\text { Yolume, } \\
f^{3}{ }^{3}\end{array}$ & $\begin{array}{l}\text { Weijht, } \\
\operatorname{lic} \text { e }\end{array}$ \\
\hline- & Four Process Valves & $-161,-371$ & $4^{\prime} 8^{\prime \prime} \times 3^{\prime} \times 2^{\prime}$ ea & 28 ea & \\
\hline - & One Process Valve & -16 & $31 \times 2, \times 21$ & 12 & \\
\hline - & 10" Process Piping & $-16^{\prime},-37^{\prime}$ & About $250^{\circ}$ & $>180^{h}$ & \\
\hline - & 4" Process Piping & $-16^{\prime}, 37^{\prime},-52^{\prime}$ & About $1000^{\prime}$ & $>110^{h}$ & \\
\hline - & $\begin{array}{l}12 " \text { and } 8 " \text { Vent } \\
\text { Piping }\end{array}$ & $0^{\prime}$ & About $100^{\prime}$ & $260^{h}$ & \\
\hline 22 & Seal Head Tank & $+52^{\prime}$ & $\begin{array}{l}51 \times 30^{\prime \prime} \times 26^{\prime \prime} \\
\left(5^{\prime} \times 20^{\prime \prime O D}\right)\end{array}$ & 27 & 1075 \\
\hline 84 & Vent Condenser & $0^{\prime}$ & $\begin{array}{l}7^{\prime} 10^{\prime \prime} \times 214^{\prime \prime} \times 14^{\prime \prime} \\
\left(4^{\prime} 7^{\prime \prime} \times 8^{\prime \prime} \mathrm{D}\right)\end{array}$ & 10 & 200 \\
\hline 84.1 & Separator & $0^{\prime}$ & $\begin{array}{l}5 \cdot 2^{\prime \prime} \times 14^{\prime \prime} \times 14^{\prime \prime} \\
\left(4^{\prime} 2^{\prime \prime} \times 10^{\prime \prime} \mathrm{D}\right)\end{array}$ & 7 & 344 \\
\hline 181 & ICL Seal Hold Tank & +52 & $4^{\prime} \times 24^{\prime \prime} \times 24^{\prime \prime}$ & 16 & \\
\hline 198 & ICL Seal Hold Tank & $+52^{\prime}$ & $4^{\prime} 24^{\prime \prime} \times 24^{\prime \prime}$ & 16 & \\
\hline 60 & Poison Tank & $+52^{\prime}$ & $6^{\prime} 9^{\prime \prime} \times 22^{\prime} \times 2^{\prime}$ & 27 & \\
\hline 913.01 & Tank & $+52^{\prime}$ & $31 \times 24^{\prime \prime} \times 24^{\prime \prime}$ & 12 & \\
\hline 270 & $\begin{array}{l}\text { Transfer Coffin } \\
\text { Transfer Coffin } \\
\text { Platform }\end{array}$ & $0^{\prime}$ & $\begin{array}{l}25^{\prime} 4^{\prime \prime} \times 2 ' 8^{\prime \prime} \mathrm{D} \\
6^{\prime} 8^{\prime \prime} \times 7 \cdot 4^{\prime \prime} \times 2 \text { × }\end{array}$ & $\begin{array}{l}192 \\
100\end{array}$ & \\
\hline 256 & Rod Drive Platforn & $0^{\prime}$ & $81 \times 144^{\prime} 69^{\prime} 4^{\prime \prime}$ & 1090 & \\
\hline - & Reinforced Concrere & $\begin{array}{l}\text { Biological } \\
\text { Shield }\end{array}$ & - & 800 & \\
\hline - & $\begin{array}{l}\text { Eight Failed Fuel } \\
\text { Element Containers }\end{array}$ & $\begin{array}{l}\text { Top of } \\
\text { SFB }\end{array}$ & $12^{\prime \prime} \mathrm{D} \times 12^{\prime}$ & $8 \mathrm{eq}^{i}$ & \\
\hline - & Component Roceperacle & Top of SFB & $12^{\prime} \times 2^{\prime} \times 2{ }^{\prime}$ & $48^{i}$ & $\cdot$ \\
\hline 178.1 & $\begin{array}{l}\text { BL } j \text { Pump Wi thout } \\
\text { Motor }\end{array}$ & -37 & $7^{\prime} 1^{\prime \prime} \times 4^{\prime} 4^{\prime \prime} \times 3^{\prime} 4^{\prime \prime}$ & 102 & ${ }^{\circ}$ \\
\hline 178.2 & BL Pump Without Motor & -371 & $7^{\prime} 1^{\prime \prime} \times 4^{\prime} 4^{\prime \prime} \times 34^{\prime \prime}$ & 102 & \\
\hline 44.1 & Main Systea Deionizer & -371 & $5^{\prime} 8^{\prime \prime} \times 4^{\prime} 8^{\prime \prime} \times 3 \cdot 8^{\prime \prime}$ & 97 & \\
\hline 44.2 & Mrin System Deionizer & -371 & $5.811 \times 4.811 \times 38^{\prime \prime}$ & 97 & \\
\hline 40.1 & Main Purge Cooler. & -371 & $19^{\prime} \times 2^{\prime} \times 2^{\prime} 6^{\prime \prime}$ & 95 & \\
\hline 40.2 & Main Purge Cooler & $-377^{\prime}$ & $19^{\prime} \times 21 \times 216^{\prime \prime}$ & 95 & \\
\hline 43 & Seal Pot & -371 & $13^{\prime} \times 218^{\prime \prime} \times 2 \cdot 8^{\prime \prime}$ & 92 & \\
\hline 105 & Hold Tank & $-16^{\prime}$ & $9 \cdot 2 \prime \times 31 \times 3 \prime$ & 83 & \\
\hline 187 & LL Cooler- & $-16^{\prime}$ & $12^{\prime} 10^{\prime \prime} \times 2 \cdot 2^{\prime \prime} \times 22^{\prime \prime}$ & .52 & $\cdot$ \\
\hline 54 & Main Systea Prefilter & $-37^{\prime}$ & $61 \times 3+\times 31$ & $54 \int_{7600}^{1150}$ & $\begin{array}{l}\text { Steel } \\
\text { Lead }\end{array}$ \\
\hline
\end{tabular}

a. Caregory A equipzent, betz-gama low level waste (Table 16).

b. Size of equiprent includes all projecting nozzles, support legs, etc.

c. Woight of equipnent is given when unusual or readily available.

a. ICL - Isolated Coolant Loop.

a. SFB - Spent Fuel Basin.

Q. With lead-shielded cask.

j. LL' Liquid Loop.

$i$. Volume of straight pipe, no bends included.

$i$. These could have internal alpha contamination and disposal in alpha trench could be required.

i. BL - Boiling Loop. 


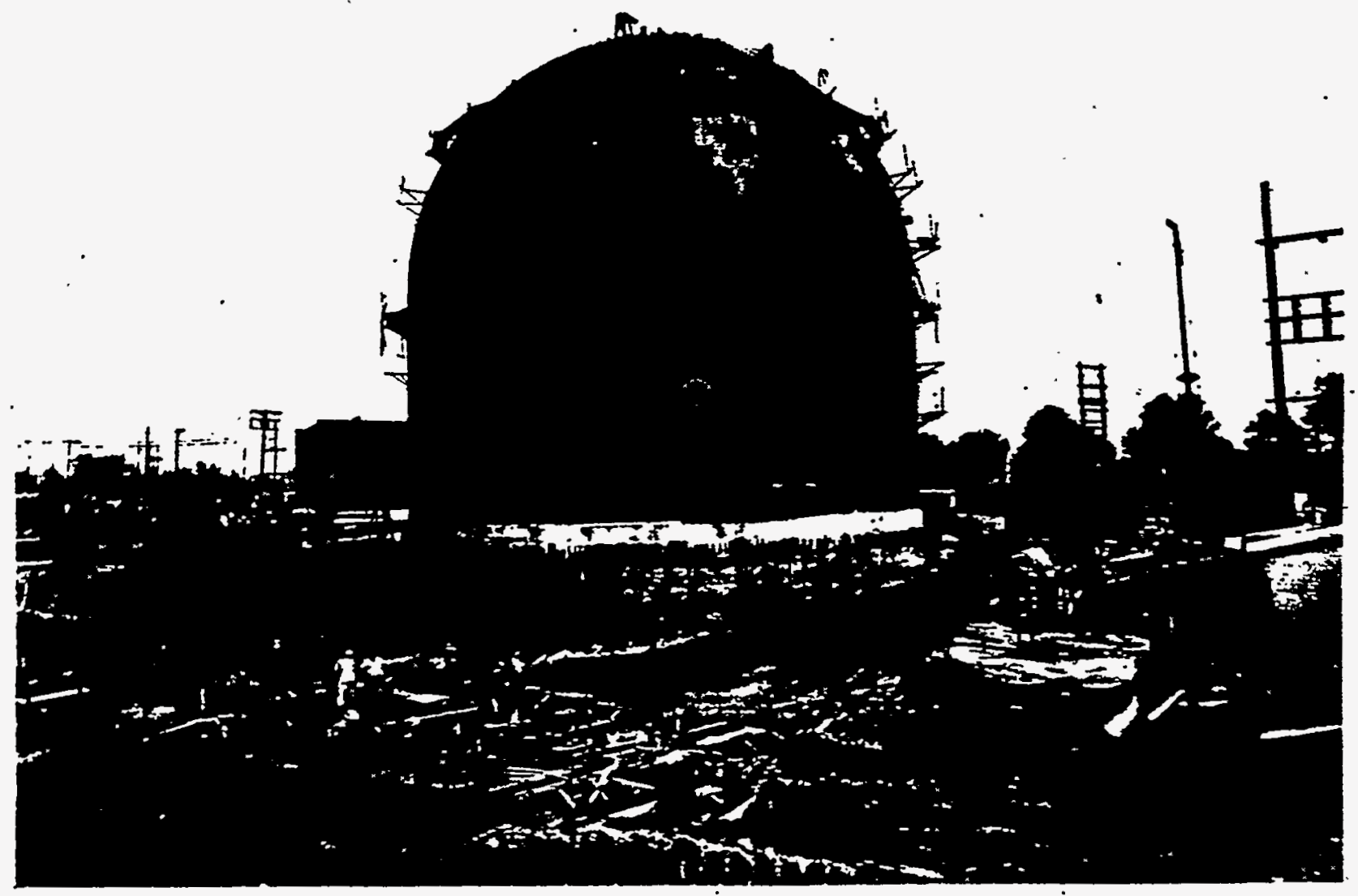

FIGURE 8. Construction of Above-Grade Steel Shell 


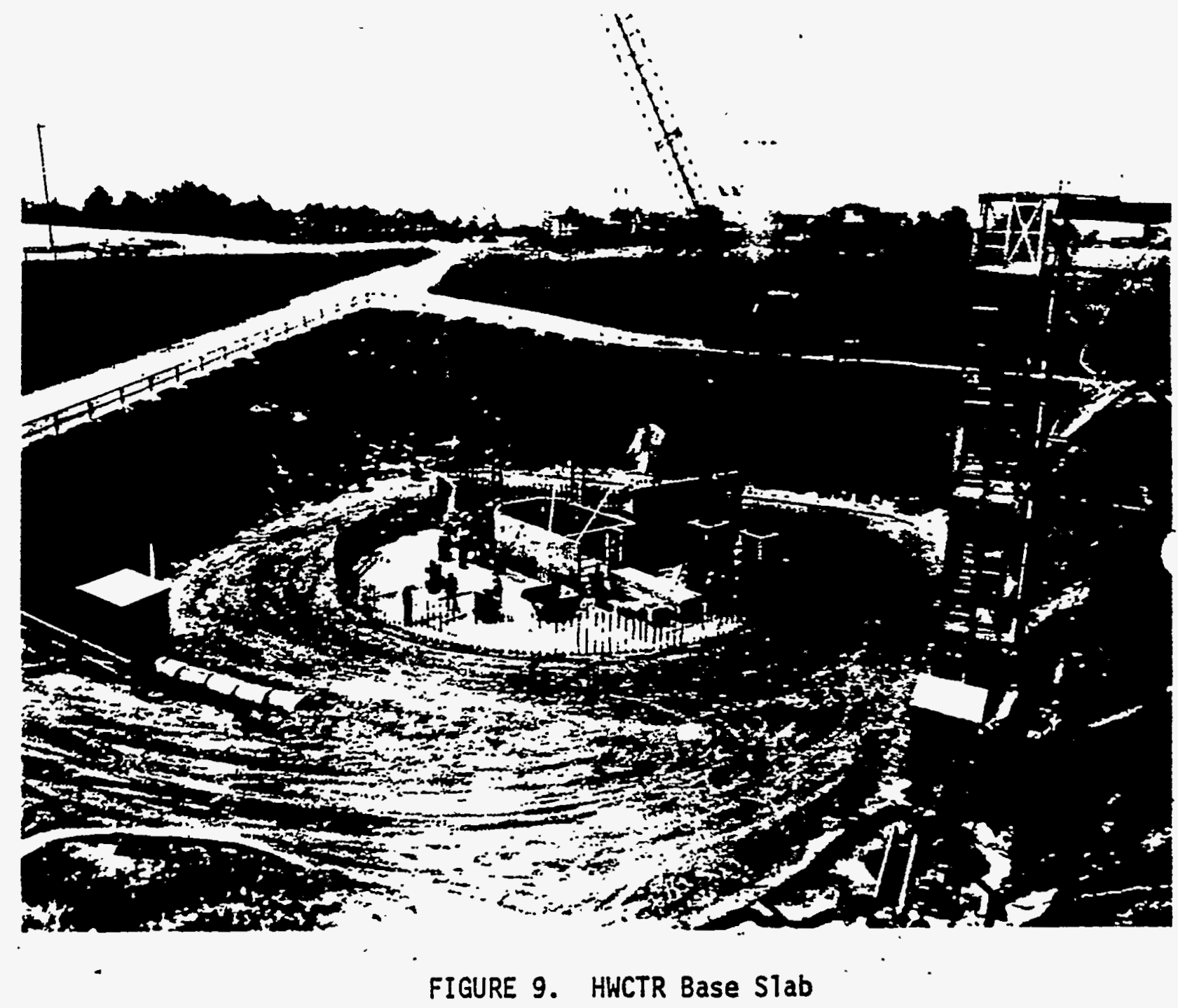




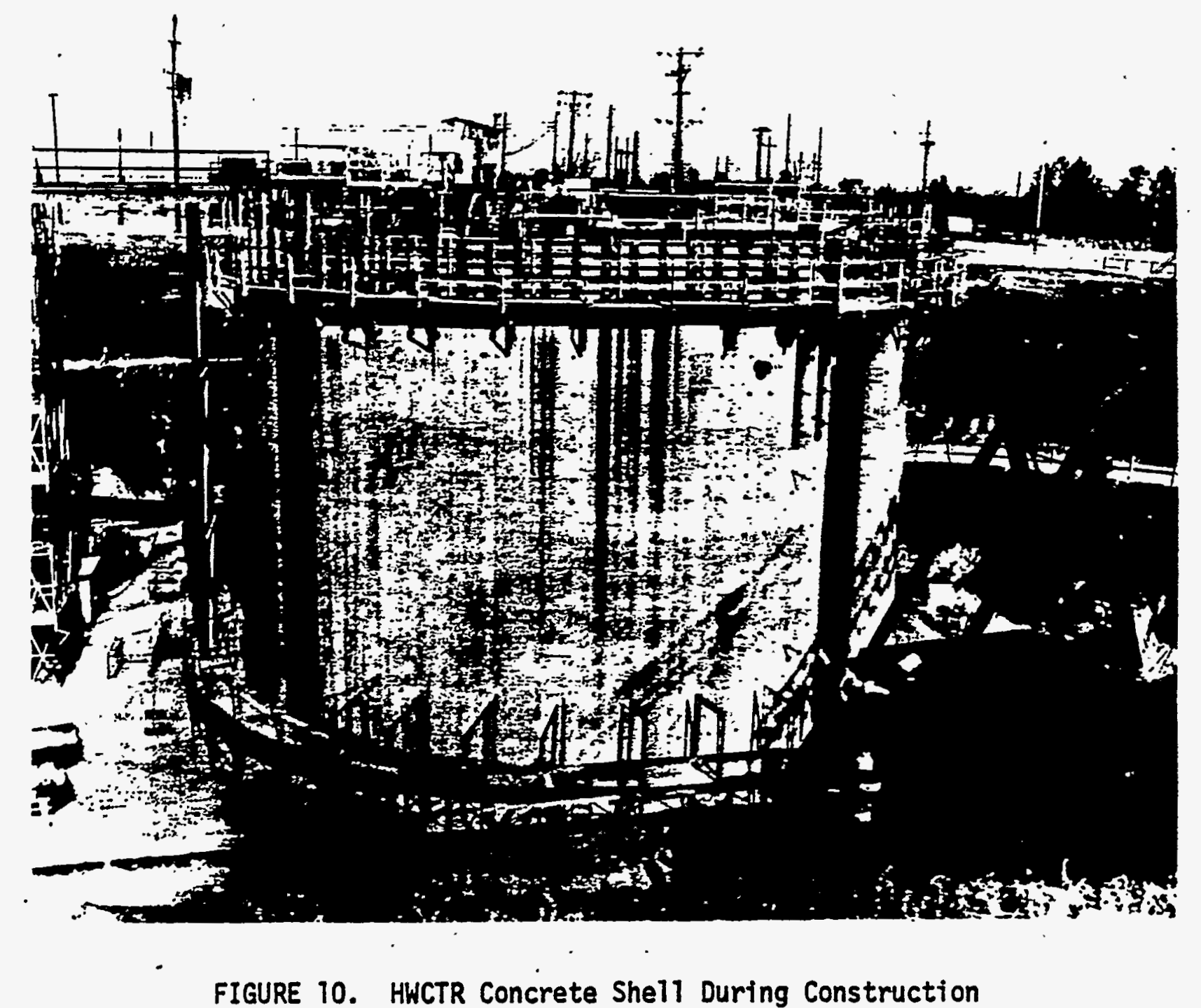

FIGURE 10. HWCTR Concrete Shell During Construction 
The most significant engineering problem is removal of the reactor pressure vessel, which weighs 100 tons and contains the highly radioactive internal thermal shield plates. As discussed on page 25 , the radiation level is only about $2-3 \mathrm{R} / \mathrm{hr}$ outside the reactor vessel but about $200 \mathrm{R} / \mathrm{hr}$ inside the vessel. Because the thick pressure vessel wall ( $3 \frac{3}{2}-4 \frac{1}{2}$ inches of carbon steel) provides shielding from the highly radioactive internal parts, removing. the reactor vessel and internal parts intact would be desirable and less costly than cutting the vessel into smaller pieces (as was done at Elk River). A crawler crane of sufficient lift capacity is available (Figure 11), and relocating the vessel to the onsite burial ground about 5 to 6 miles away via plant roads entirely within the plant security fence. is considered feasible. Removal of the reactor vessel involves the following steps (Figure 12):

3

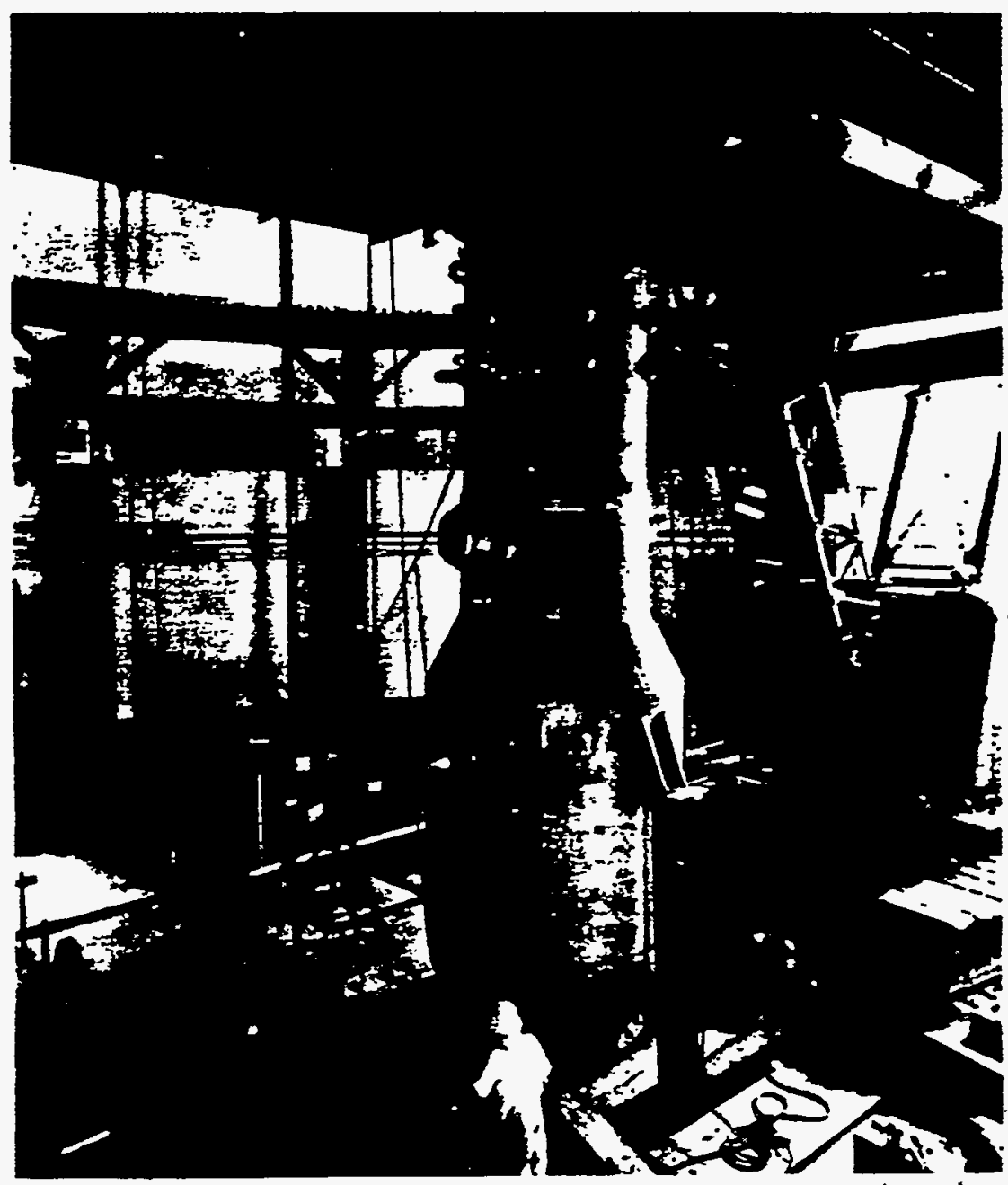

FIGURE 11. Reactor Vessel Being Moved Into Position 


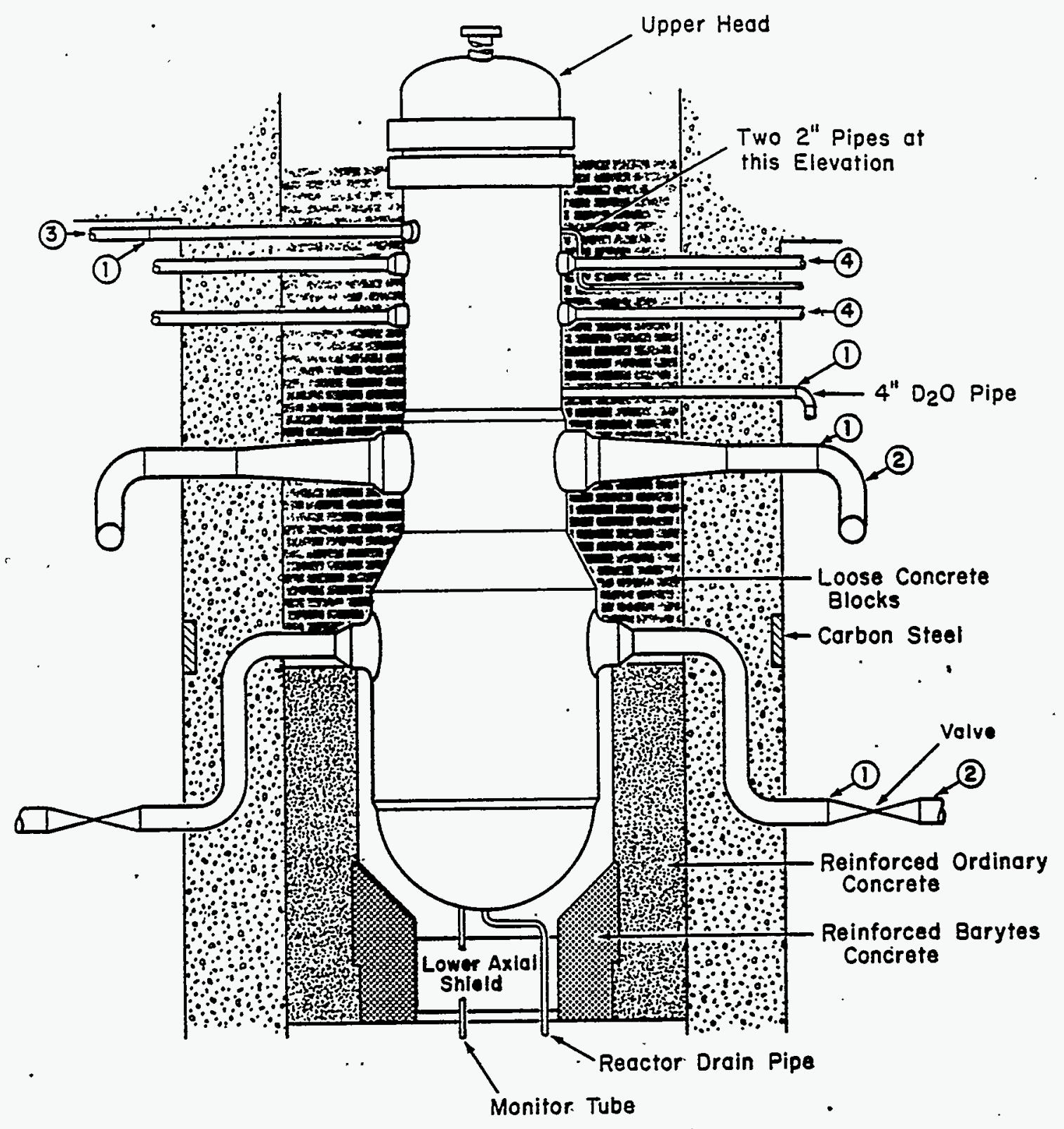

(1) Carbon Steel to Stainless Steel Transition.

(2) $10^{11}$ Carbon Steel Pipe

(3) Two $4^{\prime \prime}$ instrument Pipes at this Elevation

(4) Six 4". ICL Pipes at this Elevation (Stainless Steel) ?

FIGURE 12. Reactor Vessel and Concrete Biological Shielding to Be Removed 
- Disconnect control and saiecy rod housings from the vessel upper head, remove rod drive platfurm with housings, and seal upper head nozzles with blind flanges.

- Disconnect all monitor tube and thermocouple connections from the monitor pin sleeves beneath the lower axial shield, and seal the monitor pin sleeves with fittings that will allow the sleeves to be lifted up through the lower axial shield.

- Remove the loose concrete blocks from the cavity between the vessel neck and the poured concrete.

- Cut all the pipes that protrude radially from the pressure vessel and enter the concrete biological shield: four 10-inch pipes, seventeen 4-inch pipes, and four 2-inch pipes.

- Lift the pressure vessel out of the cavity and place it on a transport vehicle. The $2-3 \mathrm{R} / \mathrm{hr}$ general radiation level $2 \mathrm{ft}$ from the core region of the vessel will not permit extensive work near the reactor but will not require elaborate shielding for crane operators or transport vehicle drivers. However, the 10-inch nozzle openings will emit two high radiation beams from the internal shield. Temporary shielding will probably be installed in these two openings $(e . g$. lead plugs).

Measures that reduce corrosion of the reactor structure will minimize the release of radioactive corrosion products to the ground water. For this reason, the reactor vessel penetrations (cutoff nozzles) must be sealed with watertight and corrosionresistant seals to prevent water penetration. The corrosion resistance of the seals should equal that of the minimum thickness of stainless steel, i.e., 0.2-inch wall thickness of the bottom drain pipe. Additional barriers to water penetration would be provided. For costing purposes, the reactor vessel is assumed to be placed in a steel-lined concrete vault. Other methods, such as casting the reactor in concrete would be considered as part of the final design if this alternative is selected.

Removing the reactor vessel as a unit is considered to be much better than cutting up the vessel and internals for removal in smaller pieces. The cutting operation would release airborne activity (from torch cutting), which would require a confinement and air filtration system and breathing air protection for personnel and could interfere with other dismantling operation. Handing of the highly radioactive reactor internal parts would. require personnel shielding systems and shielded transport. casks and would almost certainly result in increased personnel exposure and increased risk of accidental exposure. In addition, the reactor intemal parts would be buried in containers with corrosion resistance at least equivalent to that of the reactor ' pressure vessel (minimum 0.2 inch of stainless steel): 
In the Elk River dismantlement program, the reactor vessel. was cut up into pieces for removal; however, the radioactivity level and transport conditions were very much different from those of the HWCTR. First, the radiation level of the outer surface of the reactor vessel was $30 \mathrm{R} / \mathrm{hr}$ versus $2-3 \mathrm{R} / \mathrm{hr}$ for the HWCTR vessel. Second, the disposal plan required transport of the radioactive equipment out of the state of Minnesota. Transport of the large ( $7 \mathrm{ft}$ diameter $\times 25 \mathrm{ft}$ length), highly radioactive vessel for long distances on public roads or railroads involved a number of technical and regulatory questions that encouraged cutting up the vessel. In particular, a special shipment of a reactor vessel would require a very large heavy cask to lower the radiation level to $10 \mathrm{mR} / \mathrm{hr}$ at $6 \mathrm{ft}$ and also several months of delay for approvals. In addition, a commercial burial ground would require a special review and approval by appropriate Federal and State agencies to receive such an unusual shipment.

- The lower axial shield (Figure 13) directly under the reactor vessel could be removed by lifting it straight up through the empty reactor cavity, provided that the grout or packing in the. 1-inch annular space between the shield and the surrounding concrete does not prevent upward motion. The shield (Appendix C) weighs about 6 tons, and the upper plate is activated to about 100-200. $\mathrm{mR} / \mathrm{hr}$. If the grout must be removed or loosened, access to the bottom of the annular space could be attained by removing the shield support lugs that are bolted to the pin room ceiling. Access to the top of the annular space could be attained by installing temporary shielding on top of the shield and, if necessary, around the sides of the cavity.

Portions of the concrete biological shield must also be removed. Calculations indicate that the barytes coricrete at the bottom of the reactor cavity and the $2 \frac{1}{2}-f t-t h i c k$ annular section around the core region must.be removed as shown in Figure 12. The amount of reinforced concrete to be removed (1300 $\mathrm{ft}^{3}$ ) is an estimate because the ${ }^{.59}$ Co content varies widely. As part of the final engineering design of dismantlement, the estimated amount of concrete to be removed should be refined. by taking core samples.. A good estimate is important because the concrete removal could be costly in terms of dollars and radiation exposure. At Elk River, the cost of dismantling the conarete biological shield was large and was underestimated (abqut $\$ 1.2$ million versus $\$ 0.35$ million estimate). The reinforcing steel and the confined area interfered with dismantlement and required the use of explosives. Removal of the process piping from the concrete around the reactor would require removal ' of some additional reinforced concrete (Figure 12). This additional concrete would probably not have enough radioactivity to requireburial. 


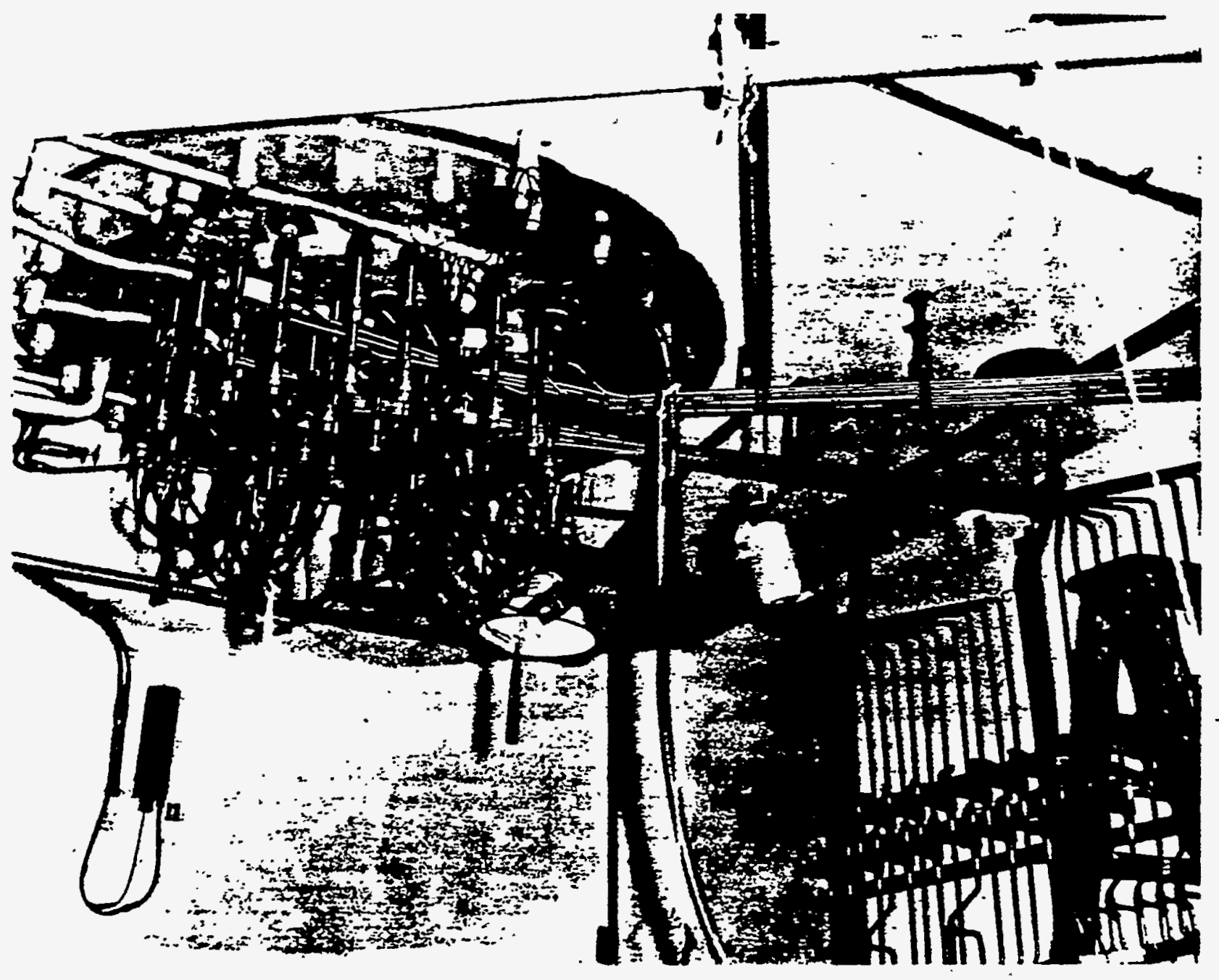

FIGURE 13. Bottom of Lower Axial Shield Showing Monitor Tubes and Segmented Support Rings 
The cost saving for simply capping the building cavity at grade level rather than removing all material to a depth of 16 $f t$ is estimated at one million dollars. This saving could be considered-if the above-grade concrete cap is not detrimental to the future site use.

\section{Entombment}

The objectives of entombment of HWCTR are 1) to provide longterm ( 100 years or longer) security for residual radioactivity and thereby minimize the risk to the public, and 2) to minimize required maintenance and surveillance of the HWCTR site.

Two configurations were considered in the conceptual design of entombment structures.

Basic Entombment (Figure 14).

- Remove all above-grade contaminated. equipment (Figures 15, 16, and 17) and piping. Place below grade.

- Remove actuator structure, leave head on reactor, and seal reactor head nozzles with blind flanges.

- Seal all concrete penetrations.

- Remove all remaining above-grade structures including steel dome and 25-ton crane for salvage or disposal.

- Cut pipes from pressure vessel at stainless steel/carbon steel transition and weld stainless steel plug in lines, minimum of 0.2 -inch thick or equivalent plug.

- Backfill building below grade with compacted earth.

- Pour a reinforced concrete pad, approximately 1-ft thick over entire grade elevation of reactor structure. The area around the reactor head is to be approximately 3 -ft thick..

- Cover the entire concrete surface with waterproof barrier. Cover with clay sloped for drainage. Seal with waterproof membrane. Install drain field to remove rainfall runoff from area.

\section{Solid Entombment}

- Include all items of basic entombment above except backfill.

- Prior to installation of roof slab, fill entire below-grade structure with concrete. instead of earth. 


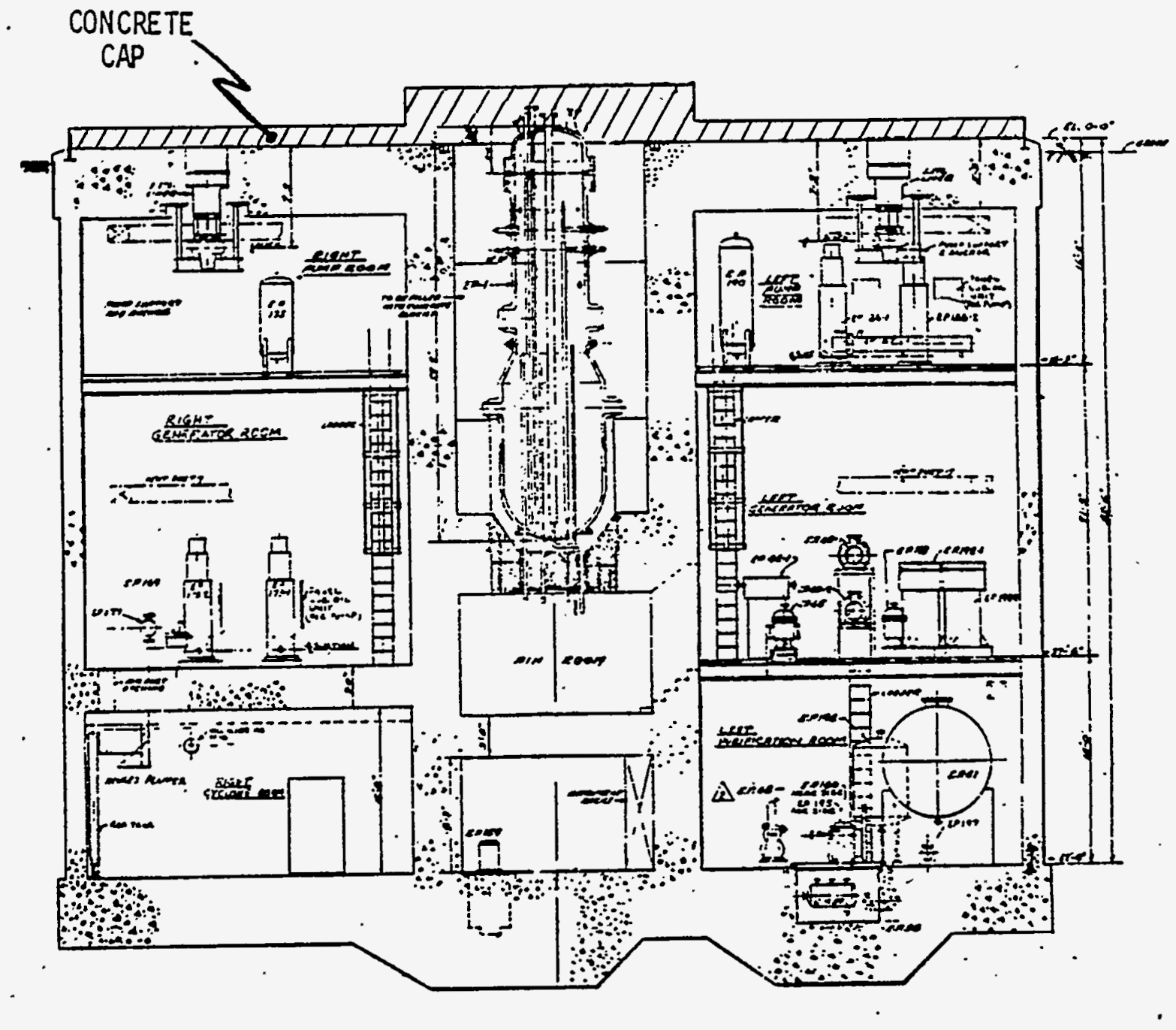

FIGURE 14. Basic Entombment 


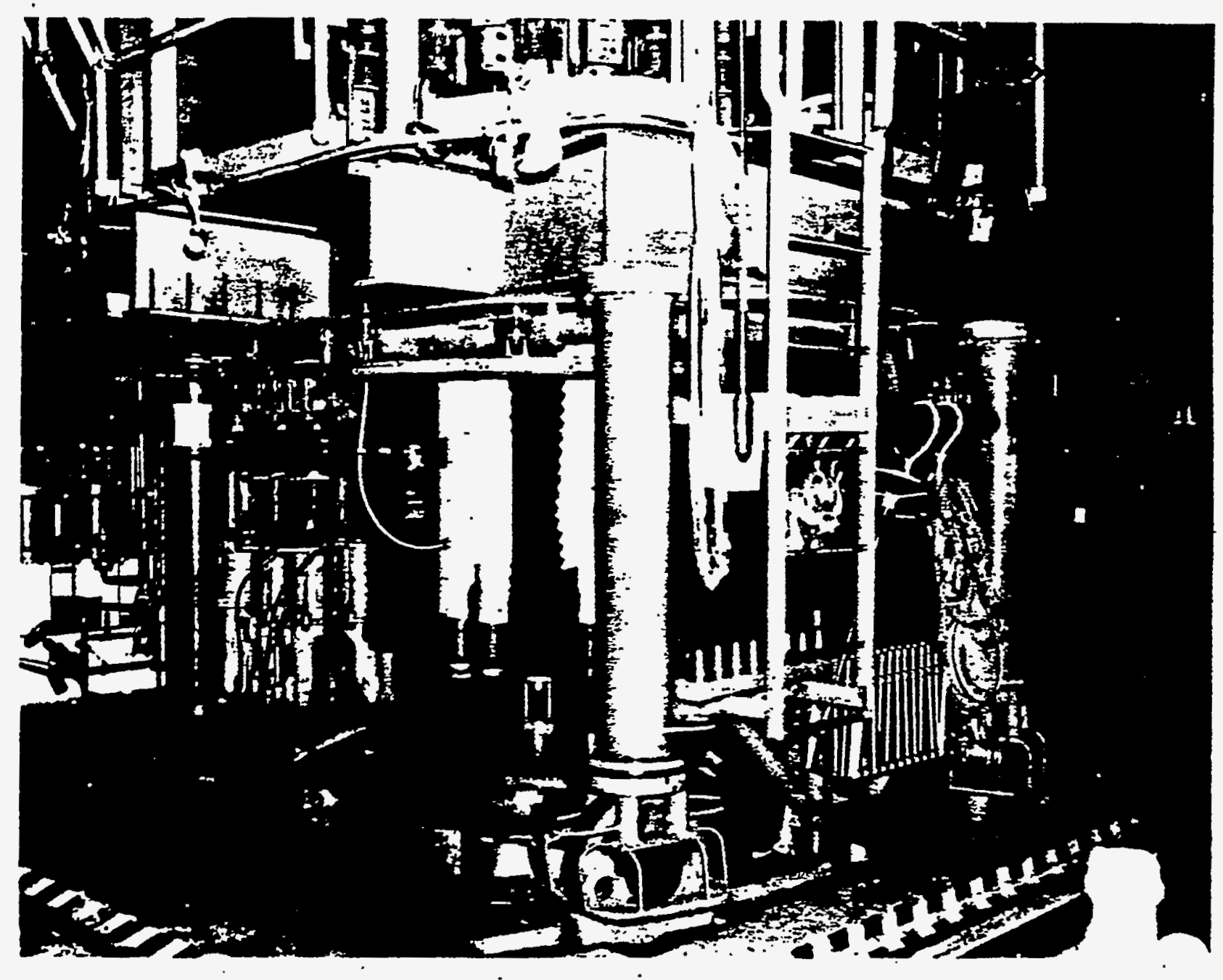

FIGURE 15. Reactor Head with Control Rod Drives 


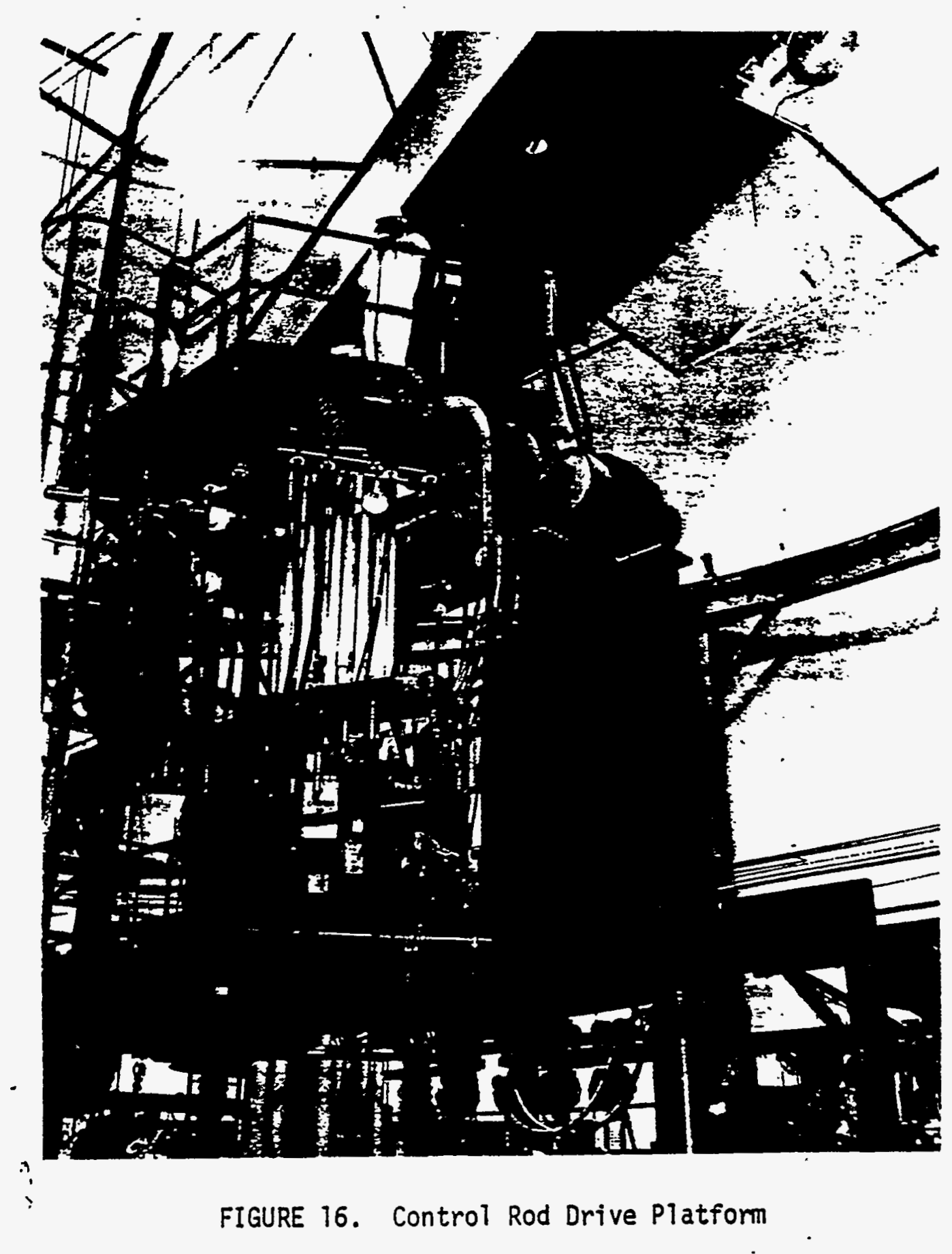




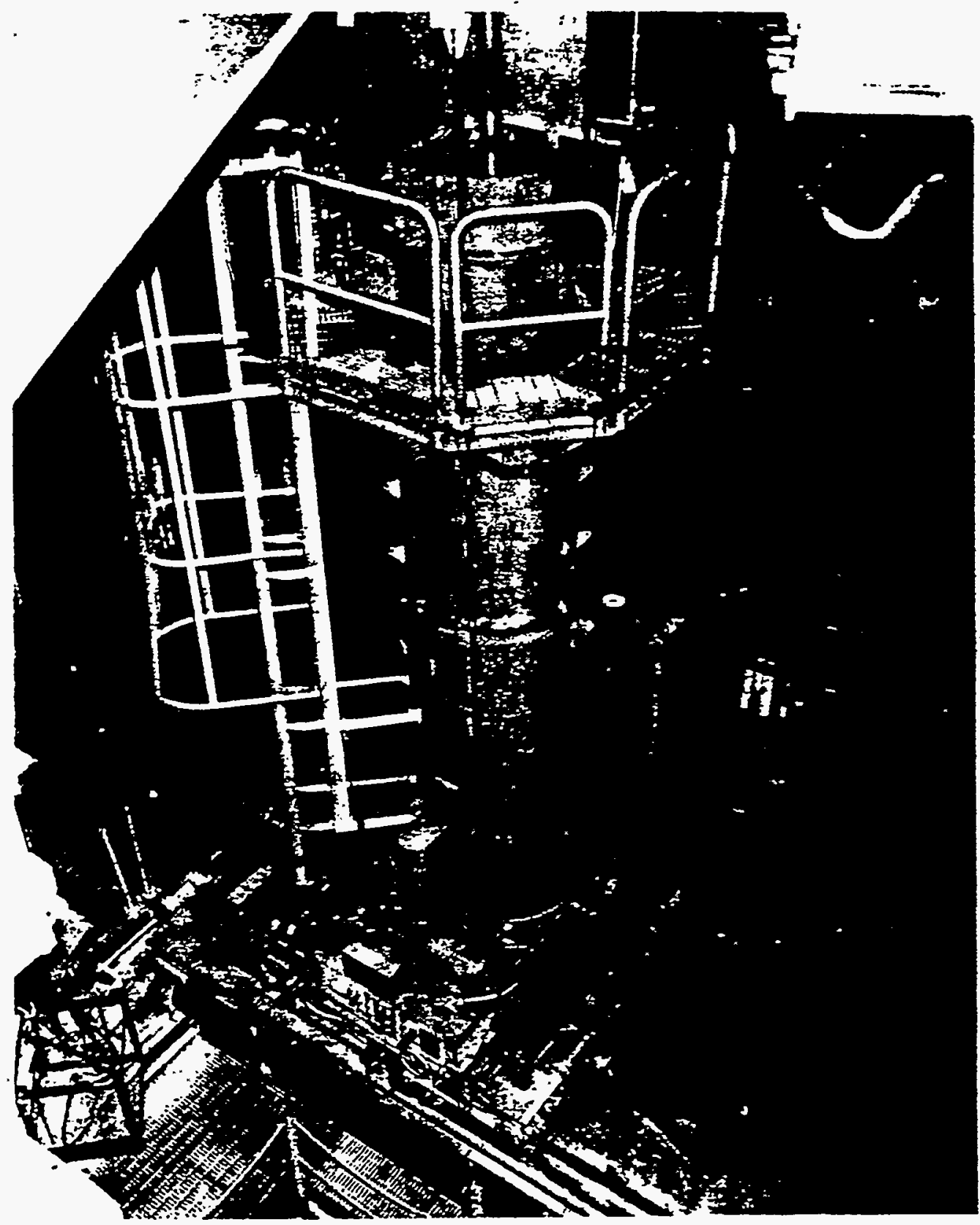

FIGURE 17. Fuel Transfer Coffịn 
Two additional configurations were considered:

1. Fill central core of below-grade building around pressure vessel, in pin room and monitor room with concrete. Encase the reactor vessel in a continuous cylinder of concrete from the foundation to grade level. Tying the pressure vessel - to the foundation in this continuous cylinder would increase the resistance to earthquakes. An earthquake analysis of the structure will be needed to determine if this is neces-. sary. This item has not been costed by the Engineering Department.

2. Use the present steel dome and concrete substructure as the entombinent structure. A11 exterior doors, hatches, or openings would be permanently sealed by welding and other methods. The dome would be stripped of insulation, sand blasted, and painted as described in the protective confinement proposal. The concept was discarded for several reasons. Physically it is similar to protective confinement except that below-grade periodic inspection is not very convenient. Reduced surveillance would decrease annual expenditures, but there is no advantage over protective confinement because:

- Physical security of the entombed radioactivity is not substantially improved over protective confinement.

- Periodic inspection allowed by protective confinement would detect defects such as any increased water seepage into the concrete substructure.

- The same yearly maintenance would be required for domed entombment as for protective confinement. The dome would require periodic exterior painting in either case.

\section{Protective Confinement}

The objective of protective confinement is to maintain the HWCTR equipment in a state of dry storage, with lower capital expenditure than that of entombment or dismantlement. The equipment would be left in place, but steps would be taken to prevent access of water to the reactor. Physical security for the radio$\rightarrow$ active inventory to prevent public exposure would be ensured by ; the current state of restricted access to the SRP site plus permissive access to the locked HWCTR area. The scope of work is as follows:

- Install flanges or welded seals on all process openings that are open or have temporary (tape and plastic) seals. 
- Cut and seal all ductwork and conduit that penetrate the exterior concrete shell.

- Remove insulation from dome, sandblast and paint the surface.

- Install moisture detectors at the lower level of the building and in the sump to detect water inleakage. Install moisture detection alarms at the patrol station in Building 704-U.

- Shut off, close, and lock all building services (except for the moisture alarm system) such.as steam,. water, and electricity to prevent fire or water leakage in the building.

- Provide multiple locked barriers to prevent unauthorized entry of the building.

- Establish wells (assume three) to monitor ground water around the building.

Replacement of tape-and-plastic seals on process openings with permanent seals is intended to prevent access of water to the reactor. Removal of equipment and pipe sampling have caused. obvious openings. However, other unknown openings probably exist, such as open sample valves, instrument tubing openings, or failed steam generator tubes. Some allowance is included in the cost estimate to develop a more comprehensive final design for water exclusion if this option is selected.

Sandblasting and painting the containment dome exterior surface after removing the adhesive bonded insulation are included to prevent further corrosion of the 3/4-inch steel shell (Figure 18). Moisture penetration of the insulation has caused significant pitting corrosion; up to 0.045 -inch penetration was observed in 1964 .

This alternative would require periodic inspection of the security fence, locked barriers, and the dome for corrosion. Some effort would be required to maintain the dome and the moisture detector system. Ready access to enter the building and investigate a moisture accumulation would be maintained.

Several options considered in developing this alternative, but not costed, are included here as additional information so that "they can be reconsidered if protective confinement is selected. 
- Pipes leading to the reactor could be cut off and sealed close to the reactor. For example, the 10-inch main system pipes could be cut off just outside the biological shield as specified for the entombment alternative. This option might be less costly and more effective than sealing the many process penetrations.

- With no insulation on the exterior of the dome the interior could reach high temperatures (perhaps $150^{\circ} \mathrm{F}$ ) on hot clear days, and this could accelerate deterioration of the building, the equipment inside, and the building seals. Some options are :

- Replace and maintain the dome insulation with new. insulation that will not cause corrosion of the steel. Insulation might be placed on the inside surface.

- Leave the existing insulation in place if the corrosion penetration rate is sufficiently low.

- Provide vents. for air circulation to prevent excess temperatures with no inșulation. 


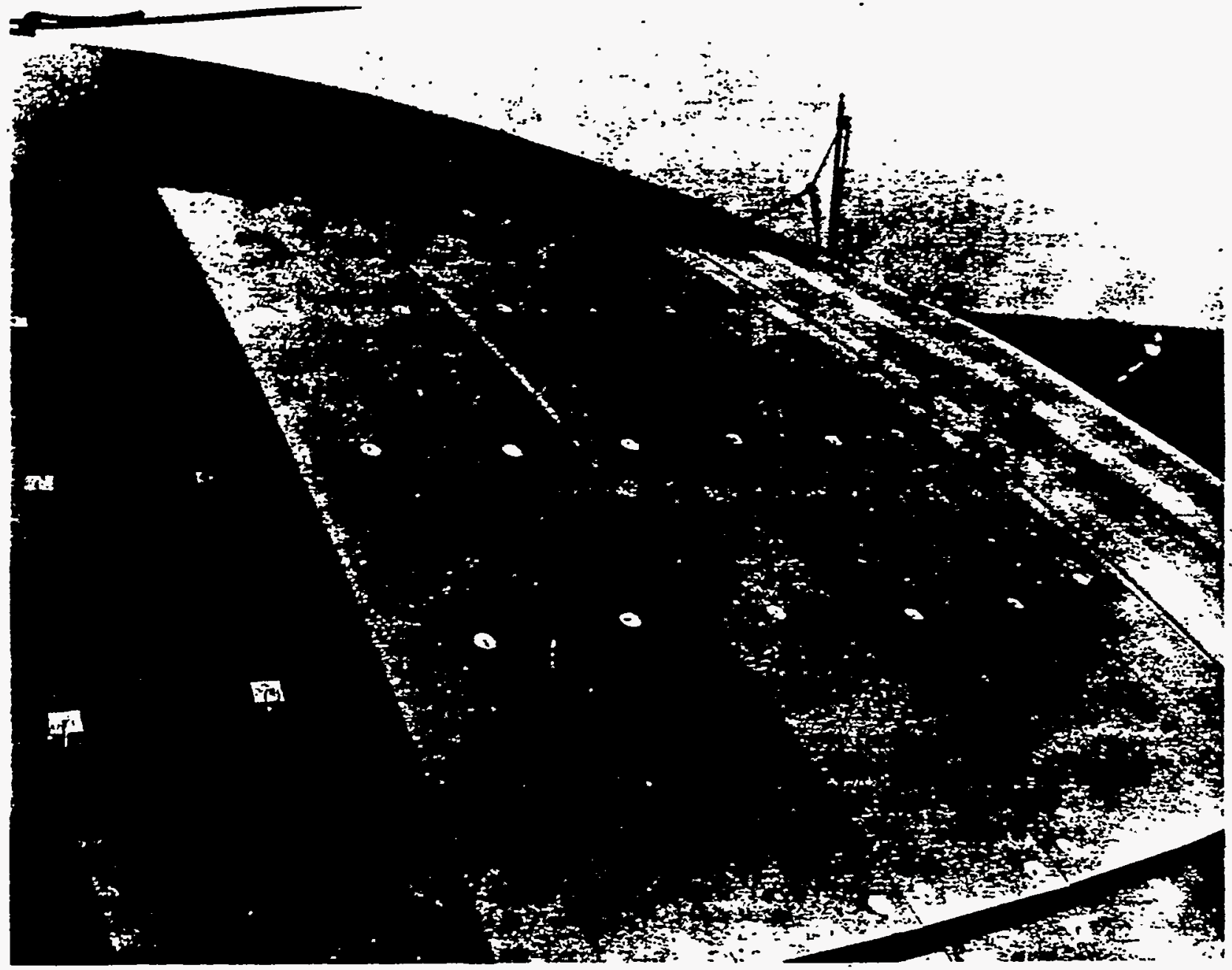

EIGURE 18. - Insulation Being Installed on Containment Shell 


\section{SAVANNAH RIVER PLANT SITE}

The Savannah River Plant site is shown in Figure 19. The site of HWCTR is at $U$ area, over 3 miles from the site perimeter. Public entrances to the Plant are manned around the clock by security forces; public traffic traverses the Plant via route SC 125 that passes with 1-1/2 miles of HWCTR. Motorists are not to leave the public route; on-duty security personnel at the $U$ site provide additional security for wayward sightseers. The HWCTR site is surrounded by a fence with a locked gate. The nearest stream to HWCTR is Upper Three Runs Creek.

The variety of nuclear operations have resulted in several activity sites as listed in Table 15. One location of special interest to the decommissioning plan is the burial ground.

The SRP burial ground occupies 195 acres located on high ground between the $200-\mathrm{F}$ and $200-\mathrm{H}$ Chemical Separations Areas. About 90 acres have been used to date, and the remainder is designed to provide space for disposal of contaminated wastes for an additional 22 years of SRP operation. The depth to the water table at the site is $40 \mathrm{ft}$; procedures require that no materials be buried closer than $10 \mathrm{ft}$ from ground water. The surface water or ground water flows either to Four Mile Creek or to Upper Three Runs Creek depending on the burial site. Normally, materials are buried in trenches $20 \mathrm{ft}$ deep by $20 \mathrm{ft}$ wide, with at least $4 \mathrm{ft}$ of soil cover. Segregation of wastes according to the type and extent of radioactive contamination is shown in Table 16.

Contaminated solid wastes from the HWCTR decomissioning would be stored at this location. Dismantlement would generate the most wastes (about 14,000. $\mathrm{ft}^{3}$ containing about $2 \times 10^{4} \mathrm{Ci}$ ). These wastes are estimated to occupy about 2 acres or 18 of the space available at the site. About $3000 \mathrm{ft}^{3}$ would probably be classified as high-level waste; the remainder would be placed in low-level trenches. The high-level waste would include primarily the reactor vessel and materials from the primary coolant system. Through 1974, about $7 \times 10^{6} \mathrm{ft}^{3}$ of solid wastes contaminated with -fission products and activation products have been buried at the storage site. As shown in Table 15, these wastes contain an estimated $10^{6}$ curies of ${ }^{60} \mathrm{Co}$. The additional quantities of Wastes from HWCTR would be a small percentage of these values.

Commercial facilities for burial of contaminated wastes are also capable of accommodating wastes from dismantlement of a reactor such as the HWCTR. For example, the Chem-Nuclear Corporation's facility in Barnwell County, S. C., contains 270 acres and is designed for operation through 1993 with a capacity ' of $8.8 \times 10^{7} \mathrm{ft}^{3}$. Through 1973, over $800,000 \mathrm{ft}^{3}$ of waste has 


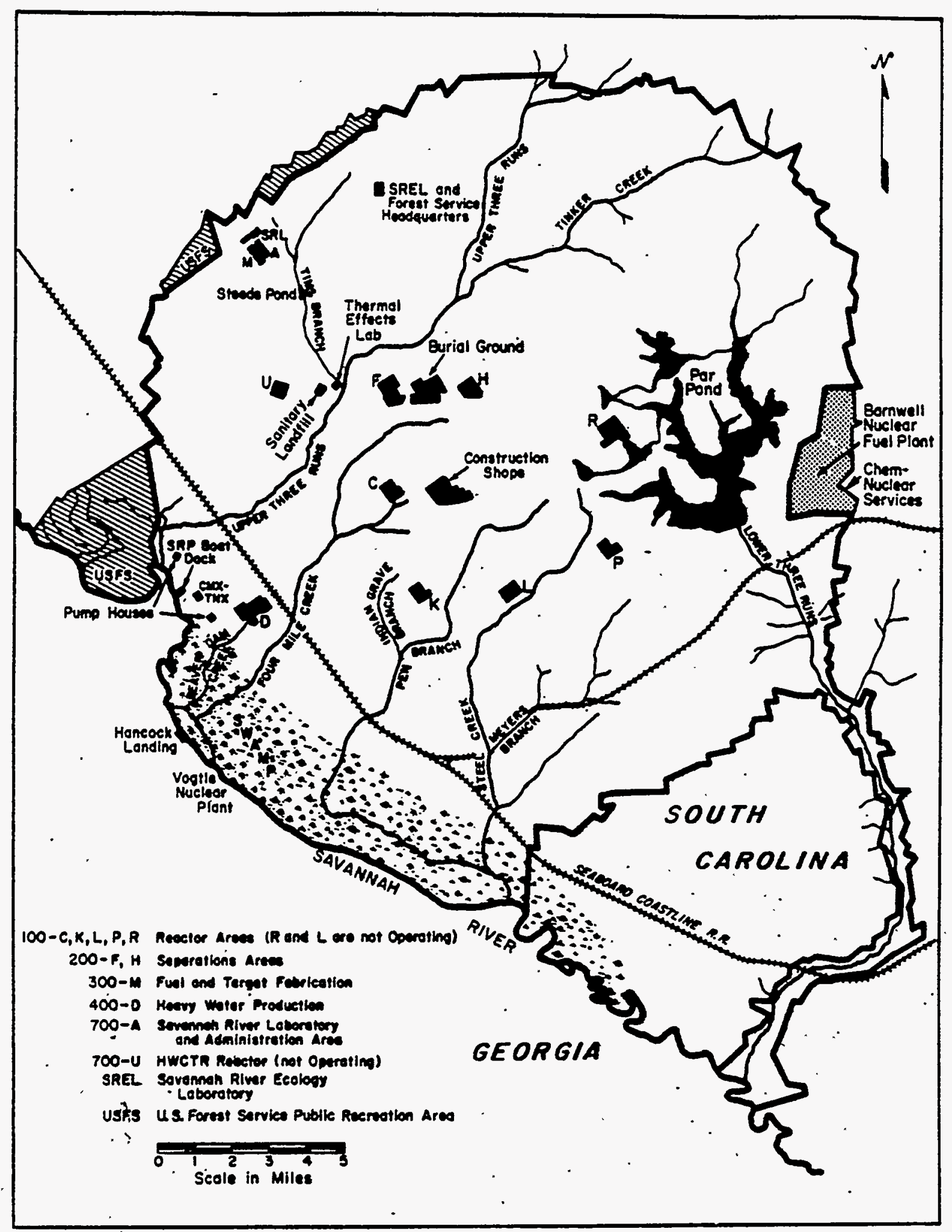

FIGURE 19. Savannah River Plant Site 
been buried at this site, containing about $120,000 \mathrm{Ci}$ of

"byproduct" material (fission and activation products). Transfer of the reactor vessel to this site would require special approval by State authorities.

TABLE 15

Activity Sites at the Savannah River Planta

\begin{tabular}{|c|c|c|c|c|c|}
\hline \multirow[b]{2}{*}{ Location } & \multirow[b]{2}{*}{ Size, acres } & \multicolumn{4}{|c|}{ Activity, Ci (12/73) } \\
\hline & & $\begin{array}{l}\text { Fission } \\
\text { Product }\end{array}$ & ${ }^{60} \mathrm{Co}$ & ${ }^{63} \mathrm{Ni}$ & $T R U$ \\
\hline $\begin{array}{l}\text { Burial Ground, } \\
\text { F \& H }\end{array}$ & $\begin{array}{l}90 \text { used, } \\
105 \text { new }\end{array}$ & $10^{4}$ & $10^{6}$ & $10^{3}$ & $10^{5}$ \\
\hline HWCTR & 1 & - & $10^{4}$ & $2 \times 10^{3}$ & - \\
\hline
\end{tabular}

a. Other major activity sites include five reactor areas, two separations areas, and SRL; see Figure 19 for dispersed locations on plant site.

TABLE 16

Savannah River Plant Radioactive Solid Waste Disposal

Category

Beta-Gamma

Low Level Waste

$<50 \mathrm{mrem} / \mathrm{hr}$ at 3 inches $<300 \mathrm{mrad} / \mathrm{hr}$ at 3 inches

High Level Waste

$>50 \mathrm{mrem} / \mathrm{hr}$ at 3 inches

$>300 \mathrm{mrad} / \mathrm{hr}$ at 3 inches

General Alpha Waste

$\because \quad<10 \mathrm{nC} \dot{\mathrm{C}} / \mathrm{g}$

Retrievable Alpha Waste.

$10 \mathrm{Mi} / \mathrm{g}$ to $0.1 \mathrm{Ci} / \mathrm{pkg}$

$>0.1 \mathrm{Ci} / \mathrm{pkg}$

Special

Process equipment, vessels, jumpers, etc:
Disposition

Low - level trench

High level trench

Alpha trench.

55-gallon drums for pad storage

55-gallon drum for storage in concrete container

Plans developed on each case separately 


\section{SAFETY ANALYSIS}

After decomissioning HWCTR, the residual radioactivity might cause a radiation dose to the public via two general mechanisms: accidental direct exposure to curious individuals who gain unauthorized access to the vicinity of the reactor vessel or accidental release of water that has contacted the reactor internals and then is released to the plant system. The likelihood of either occurrence is extremely small for all alternatives. Physical security associated with current site activity provides a high degree of protection against unauthorized access. No significant amounts of activity reach the plant streams under pessimistic consequence analyses that assume structural failures without corrective action. The safety analysis is summarized in Table 17.

TABLE 17

Decommissioning Safety Summary

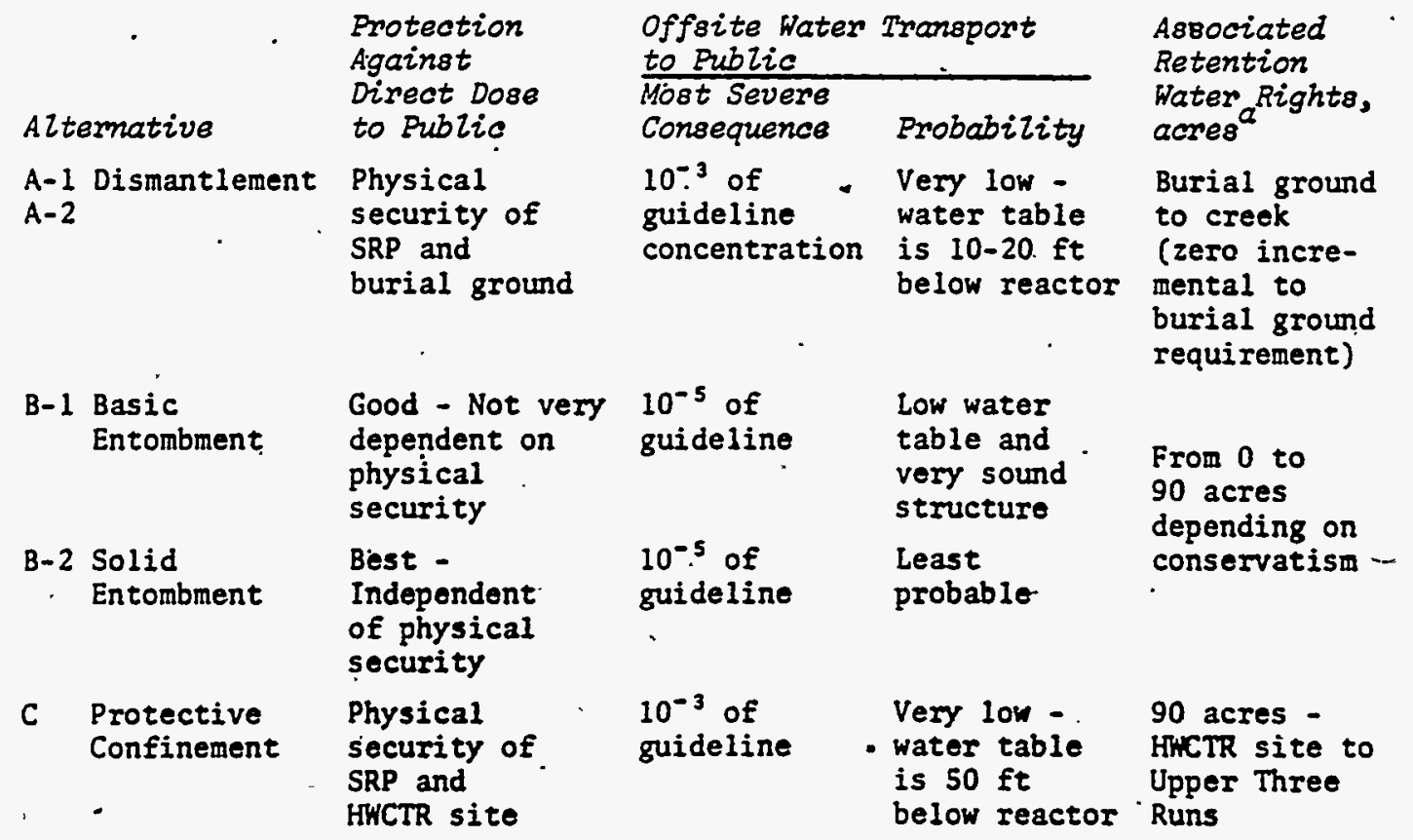

a. Only meaningful if some reduction is made in the current SRP site. 


\section{Direct Exposure}

The likelihood of radiation emitted from HWCTR causing any significant dose to the public after decommissioning is judged to be extremely low for any alternative.

\section{Dismantling (A-1 or $A-2)$}

If HWCTR were dismantled, the reactor vessel would be buried in a vault under $4^{\circ} \mathrm{ft}$ of earth in the site burial ground. Site security has been previously discussed. Admission to this SRP site is made only to security-cleared personnel or authorized visitors escorted by cleared personnel. Some closely regulated travel on a public road (SC 125) is supervised by SRP Security. Unauthorized entry to the burial ground would require breaching two fences; furthermore, direct exposure would require digging up the reactor vessel vault. The vessel vault could be filled with concrete to immobilize the activity and would also reduce the emitted radiation.

\section{Entombment (B-1 or $B-2)$}

Entombment is less reliant on physical site security to avoid dose-to-man because the activity is fixed in a concrete structure and the external dose is essentially background. The basic entombment structure at the HWCTR site would be inside the site security fence and would be much more formidable for entry. Ground level radiation would be background. Entry could be gained only by penetrating 1-3 ft of reinforced concrete. Solid entombment further reduces the likelihood of public access to the activity.

\section{Protective Confinement}

The protective confinement mode is most dependent on physical security to prevent exposure of an unauthorized member of the public. Multiple locked barriers are now and will continue to be provided. Presently the HWCTR site is surrounded by a locked security fence. Access to authorized personnel is permitted either by key or by security personnel through the office wing (Figure 1). The HWCTR site is further isolated from the public because of its iocation in the security area of the SRP site. If warranted under. 'the protective confinement mode, the building doors and hatches 'could be welded shut or heavily locked. However, welded closires would interfere with surveillance of the system. Plant security personnel make frequent patrols inside the SRP site area. 
For accidental or inadvertent radiation exposure to occur, some individual would have to break through a manned security fence, through a second locked fence or security checkpoint then deliberately break locks or welds to gain entrance to the HWCTR building. Inside the building the radiation levels in most areas are much less than $3 \mathrm{mR} / \mathrm{hr}$. Any exposure to an unauthorized individual could be only from an incredibly determined and deliberate effort. Over $99.99 \%$ of the residual activity is contained in the reactor vessel, which is inaccessible without use of highly sophisticated tools and a heavy crane (now disabled) to lift the reactor head. The highest current level of radiation accessible in the building outside the biological shield is 200 $\mathrm{mR} / \mathrm{hr}$ at the cyclone room sample lines. In 30 years, the radiation level will be $<4 \mathrm{mR} / \mathrm{hr}$ (1 $\mathrm{mR} / \mathrm{hr}$ after 40 years).

The physical security for all residual radioactive material from the HWCTR will exceed that prescribed in Regulatory Guide 1.86, Termination of Operating Licenses for Nuclear Reactors, under the category of "possession-only license." The Guide requirements state:

"a. Physical security to prevent inadvertent exposure of personnel should be provided by multiple locked barriers. The presence of these barriers should make it extremely difficult for an unauthorized person to gain access to areas where radiation or contamination levels exceed those specified for a dismantled facility (Table 8); these levels specified are about twice background. To prevent inadvertent exposure, radiation areas above $5 \mathrm{mR} / \mathrm{hr}$, such as near the activated primary system of a power plant, should be appropriately marked and should not be accessible except by cutting of welded closures or the disassembly and removal of substantial structures and/or shielding material. Means such as a remote-readout intrusion alarm system should be provided to indicate to designated personnel when a physical barrier is penetrated. Security personnel that provide access control to the facility may be used instead of the physical barriers and the intrusion alarm system.

b. The physical barriers to unauthorized entrance into the $\rightarrow$ facility, e.g., fences, buildings, welded doors, and access openings, should be inspected at least quarterly to assure that these barriers have not deteriorated and that locks and locking apparatus are intact." 
Consequence Analysis

The activity remaining in HHCTR consists of ${ }^{55} \mathrm{Fe},{ }^{60} \mathrm{Co},{ }^{63} \mathrm{Ni}$, and small amounts of plutonium from fuel failures. After briefly discussing the reasons why plutonium and ${ }^{60} \mathrm{Co}$ are not considered relevant to this analysis of offsite dose effects, the effects of highly unlikely failures postulated after decomnissioning HWCTR are analyzed with emphasis on ${ }^{63} \mathrm{Ni}$. Conservatisms used in the analysis are given in Table 18 , and the results are compared in Table 19. The conclusions are:

- All alternatives involve a low risk of public exposure.

- Dismantlement centralizes surveillance at the site burial ground.

- Basic entombment fixes the activity but surveillance is limited; solid entombment provides the best security of HWCTR activity. The justification to retain water rights for entombment is questionable.

- Protective confinement is most dependent on current site size and vitality.

TABLE 18

\section{CONSERVATISMS}

- Very early failure of structure (20 years) with no corrective action.

- Corrosion rates of carbon or stainless steel increased by a factor of 10 over nominal values for cold water corrosion.

- All corrosion product dissolves or is suspended; no credit for large pieces of metal not transported by the water.

- No credit for ion exchange or retention of solid corrosion product (containing activity) by soil outside the decommissioning structure.

- Normal nickel concentration assumed for plant streams; Upper Three Runs should contain higher natural nickel from 300 Area operations, and thus uptake of radioactive nickel may be retarded.

- Water seepage from the structure is assumed to be replenished so that the maximum concentration of iron corrosion product in the water is maintained, 
TABLE 19

Consequence Analysis

$\begin{array}{lllll} & \begin{array}{l}\text { Maximum } \\ \text { Concentration in } \\ \text { Reactor Vessel, } \\ \mu C i / c c\end{array} & \begin{array}{l}\text { Voliume of Hater } \\ \text { Seeping to Creek, } \\ f t^{3} / \mathrm{yr}\end{array} & \begin{array}{l}\text { Maximum } \\ \text { Creek Con- } \\ \text { centration, } \\ \mu C i / c c\end{array} & \begin{array}{l}\text { Eraction } \\ \text { of }\end{array} \\ \text { Alsernative } & 5 \times 10^{-5} & 2,000 & 8 \times 10^{-110} & 1 / 1500 \\ \text { Dismantlement } & 5 \times 10^{-5} & 1,300 & 5 \times 10^{-12} & 1 / 2500 \\ \text { Entombment } & 5 \times 10^{-4} & 20,000 & 3 \times 10^{-10} & 1 / 400 \\ \text { Protective } & 1.8 \times 10^{-4} & & & \end{array}$

a. Based on Four Mile Creek flow of $20 \mathrm{cfs}$; other concentrations are based on Upper Three Runs ceek flow of 200 cfs.

\section{PZutoniun (TRU)}

The consequence of releasing the residual amounts of $239 \mathrm{Pu}$ is negligible. Even if all the ${ }^{2{ }^{9} \mathrm{Pu}}$ were released at one time, its effect would not be significant.

The residual plutonium in the HWCTR site is in corrosion products in the external piping from fuel failures (8-mg release, estimate). The exact amount remaining in the piping is difficult to estimate but is probably less than $10 \mathrm{mg}$ of ${ }^{239} \mathrm{Pu}$ or $620 \mu \mathrm{Ci}$ (samples indicated $13 \mathrm{mg}, 800 \mu \mathrm{Ci}$ ).

If $10 \mathrm{mg}$ of ${ }^{239} \mathrm{Pu}$ were dissolved in $3,700,000$ gallons of water, the concentration would be about $4.4 \times 10^{-8} \mu \mathrm{Ci} / \mathrm{cc}$, the guideline concentration. This volume of water corresponds to 40 minutes of flow in Upper Three Runs Creek or about five times the volume of the HWCTR building.

Therefore, ${ }^{239} \mathrm{Pu}$ does not contribute a significant amount of radioactivity to the postulated release model compared to ${ }^{63} \mathrm{Ni}$ or ${ }^{60} \mathrm{Co}$.

${ }^{\circ} \mathrm{COO}$

The radiation level in HWCTR is almost exclusively from ${ }^{60} \mathrm{Co}$; thus, as ${ }^{60} \mathrm{Co}$ decays, the radiation levels will decrease. In 35 years, the radiation levels will be 18 of current values, and any construction work will be simplified greatly.

The consequence of ingesting water with ${ }^{6}{ }^{\circ} \mathrm{Co}$ from water that contacts and corrodes the thermal shield of the HWCTR is currently about $40 \%$, of the total radiation burden to man. However, within 20 years, the contribution of the ${ }^{60} \mathrm{Co}$ becomes less than $5 \%$ of 
the total (and less than $1 \%$ in 35 years). None of the decommissioning alternatives involve credible release mechanisms on such a short time interval. Therefore, only ${ }^{6}{ }^{3} \mathrm{Ni}$ will be considered in consequence analyses given in the next section.

${ }^{63} \mathrm{Vi}$

The sequence of events discussed below shows that even for highly unlikely postulated failures the consequences to the public for release of radioactivity are significantly less than the guideline for any of the decommissioning modes (Table 19).

\section{Dismontlement Release Model}

1978.

Reactor dismantlement complete. Pressure vessel removed intact and placed in vault in burial ground. Plugs in pressure vessel assumed to be at least equivalent to 0.2 inch of stainless steel in thickness. Immediate water invasion of vault is postulated. . Vault is assumed to be $10 \times 10 \times 37 \mathrm{ft}$ long.

Water starts to corrode through pressure vessel at thinnest section of stainless steel (assumes only 0.2 inch of stainless steel drainline): Corrosion rate is assumed to be 10 times the rate of general corrosion of stainless steel $(10 \times 0.0001 \mathrm{inch} /$ year $=$ $1 \mathrm{mil} / \mathrm{yr}$ ). No credit is taken for saturation of water in vault with steel corrosion products. Chemical saturation of the water would arrest any further corrosion after several days when equilibrium is reached. Thus, with stagnant water in the vault, there is no mechanism for corroding through the pressure vessel. Further intrusion of fresh ground water is assumed. (2000 $\left.\mathrm{ft}^{3} / \mathrm{yr}\right)$.

2178

Water penetrates into reactor vessel. The activity of the water , inside the pressure vessel now increases to a maximum from corrosion of the stainless steel thermal shield: Again, no credit is taken for chemical saturation of this stagnant water which would

- inhibit further corrosion. Activity is $5 \times 10^{-5} \cdot \mu \mathrm{Ci} / \mathrm{cc}$ of ${ }^{6}{ }^{3} \mathrm{Ni}$ in water in the vault. This activity is about 400 times the guideline concentration. The yearly rainfall associated with the vault

$\because$ surface area $\left(400 \mathrm{ft}^{2}\right)$ is about $2000 \mathrm{ft}^{3}$ or 15,000 gallons.

This water is postulated to seep out of the pressure vessel, through the reactor building and into the water table $(10-20 \mathrm{ft}$ below the vault): 
No credit is taken for the vault that might provide additional holdup for the water and permit further radioactive decay. No credit is taken for slow transit time of the contaminated water from the vault to the water table.

\section{8}

Water migrates to Upper Three Runs Creek. The migration time through the water table is calculated to be more than 100 years (115 to 150 years).

The activity of the ${ }^{63} \mathrm{Ni}$ in the creek is calculated assuming this 100-year migration (one half-life of decay) plus the dilution by the creek (factor of $3 \times 10^{6}$ ) assuming that the contaminated water enters the creek over a one-year period. No credit is taken for ion exchange. in the soil between the reactor and the creek. Decontamination factors for soil of about $10^{5}$ in 5 meters are reported in the literature. Such decontamination factors would result in virtually no measurable activity in the ground water just a few dozen meters from the burial ground site.

Activity in Upper Three Runs Creek is $8 \times 10^{-12} \mu \mathrm{Ci} / \mathrm{cc}$ of ${ }^{63} \mathrm{Ni}$. This activity is about $1 / 15,000$ th of the guideline concentration. Therefore this release to the public would be negligible.

If the activity migrates to Four Mile Creek instead. of Upper Three Runs Creek (depending. on location in the burial ground), the activity concentration in Four Mile Creek will be about 10 times greater because of lower flow rate. This activity would be about 1/1500th of the guideline concentration and thus negligible.

Entombment

1978

Reactor entombed. Reactor vessel sealed with plugs welded closures at least equivalent to 0.2 inch of stainless steel in. thickness. Reactor building not filled with concrete. This model analyzes basic entombment. It is therefore conservative for the solid entombment which is a more secure and substantial structure.

2000

Reactor building around pressure vessel fills with water and pressure vessel begins to corrode. This is a conservative assumption. No credible mechanism can be postulated for total roof failure this quickly. Entombment structures of this type have been designed for 100 to 1.40 year lives. Assuming (1) the roof fails, (2) water accumulates in the reactor building from rainfall 
of 60 inches/year (SRP average is less than 50 inches/year), (3) all rainfall over area of building going into building, (4) no water seeping out, (5) no water evaporating, the time required to fill the building to the level of the thermal shield would be about 5-10 years. With the purge rainfall assumed later, $100 \mathrm{yr}$ would be needed and activity concentrations would be halved because of ${ }^{63} \mathrm{Ni}$ decay.

2200

Water in building corrodes through pressure vessel at thinnest section of stainless steel (assumes only 0.2 inch of stainless stee 1 drain line). Assumed at 10 times the rate of general corrosion of stainless steel $(10 \times 0.0001 \mathrm{inch} / \mathrm{year}=1 \mathrm{mil} / \mathrm{yr})$. No credit is taken for saturation of water in building with steel corrosion products. This chemical saturation of the water would arrest any further corrosion after several days when equilibrium is reached. Thus without inflow of rainwater, there is no mechanism for the stagnant water in the reactor building ever corroding through the pressure vessel.

The activity of the water inside the pressure vessel now increases to a maximum from corrosion of the stainless steel thermal shield. Again, no credit is taken for chemical saturation of stagnant water that would inhibit any further corrosion.

Activity is $5 \times 10^{-5} \mu \mathrm{Ci} / \mathrm{cc}$ of ${ }^{63} \mathrm{Ni}$ in water in HWCTR building. This activity is about 400 times the guideline concentration (Table 9).

A water volume of 10,000 gallons per year is assumed to enter the reactor vessel. "A similar volume of dispersed water is postulated to seep out of the pressure vessel, through the reactor building and into the water table, which is $30 \mathrm{ft}$ below the building foundation. No credit is taken for dilution of 4000 gallons of water in the pressure vessel (needed to submerge the highly activated shield in the lower half of the vessel) by the larger volume of uncontaminated water in the reactor building (about $10^{6}$ gallons). This dilution would lower the concentration to the order of $10^{-8}$ - $\mu \mathrm{Ci} / \mathrm{cc}$ which is less than the guideline concentration (Table 9).

No credit is taken for the concrete foundation which is substantial and would provide additional holdup time for the water and further radioactive decay. No credit is taken for slow transit time of the contaminated water from the building foundation to the water table or for unequal mixing.

* Purge volume corresponds to annual rainfall over a 9-ft radius circle (about to the area of the tomb roof structure shown in Figure 14) 
Water migrates to Upper Three Runs Creek. The migration time through the-water table is calculated to be more than 100 years $(115$ to $150 \mathrm{yr})$... The activity of the ${ }^{63} \mathrm{Ni}$ in the creek is calculated assuming this 100-yr migration (half-life of decay) plus the dilution by the creek $\left(5 \times 10^{6}\right)$ assuming that the contaminated water enters the creek over a one-year period. No credit is taken for ion exchange in the soil between the reactor and the creek. Decontamination factors for soil in the order of $10^{5}$ in 5 meters have been found in the literature. Such contamination factors would result in virtually no measurable activity in the ground water just a few dozen meters from the HWCTR site. Decontamination factors for the soil around the HWCTR have not been measured but could be considered for future plans if entombment or protective confinement is selected for decomissioning.

Activity in Upper Three Runs Creek is $5 \times 10^{-12} \mu \mathrm{Ci} / \mathrm{cc}$ of ${ }^{6}{ }^{3} \mathrm{Ni}$. This activity is about 1/2500th of the guideline concentration (Table 9); therefore this release to the public would be negligible.

\section{Protective Confinement}

Year

1978

Protective confinement completed. Reactor sealed by closing penetrations in carbon steel piping.

2000

Reactor building fills with water by dome failure plus no corrective action.

2006

Water in reactor building corrodes into pressure vessel. Corrosion path is. shorter than entombment mode because it is through the 10-inch carbon steel line. The rate assumed is 10 times the general corrosion rate for carbon steel (10 x.0.006 inch $/$ year $=60 \mathrm{mils} / \mathrm{yr}$ ). As in the entombment case this takes. no credit for corrosion decrease when the stagnant water becomes saturated by corrosion products.

Activity is $1.8 \times 10^{-4} \mu \mathrm{Ci} / \mathrm{cc}$ of ${ }^{6}{ }^{3} \mathrm{Ni}$ in water (in reactor). This activity is about 700 times the guideline concentration (Table 9). 
The building must fill with water before water can corrode into the vessel; rainfall (estimated as $20,000 \mathrm{ft}^{3} / \mathrm{yr}$ based on a $70-\mathrm{ft}$ diameter circle, and $5 \mathrm{ft}$ of rain) displaces this volume of water to the ground water annually.

As in the previous case of entombment, this water is postulated to seep out of the pressure vessel, through the reactor building, and into the water table which is $30 \mathrm{ft}$ below the building foundation. No credit is taken for dilution of the water in the pressure vessel by the larger volume of water in the reactor building (about $10^{6}$ gallons). Dilution would lower the concentration to the order of $10^{-7} \mu \mathrm{Ci} / \mathrm{cc}$ which is about the guideline concentration; it is highly unlikely that the saturation value would be reached in all water in the building.

No credit is taken for the concrete foundation, which is a substantial structure that would provide additional holdup time for the water and thereby permit further radioactive decay. No credit is taken for slow transit time of the contaminated water from the building foundation to the water table.

2106

Water migrates to Upper Three Runs Creek. The migration time through the water table is calculated to be more than $100 \mathrm{yr}$ (115 to $150 \mathrm{yr}$ ). The activity of the ${ }^{63} \mathrm{Ni}$ in the creek is calculated assuming this 100-yr migration (which is another halflife of decay) plus the dilution by the creek $\left(3 \times 10^{5}\right)$ assuming that the contaminated water enters the creek over a one-year period. No credit is taken for ion exchange in the soil between the reactor and the creek.

Activity in Upper Three Runs Creek is $3 \times 10^{-10} \mu \mathrm{Ci} / \mathrm{cc}$ of ${ }^{6}{ }^{3} \mathrm{Ni}$. This activity is about $1 / 400$ th of the guideline concentration; therefore this release to the public would be negligible.

The most severe effect postulated via natural events (earthquake, tornado, and flood) at the Savannah River Plant site is to initiate the failures in the decommissioned HWCTR structures that lead to the sequence of events described in the previous section. With onsite surveillance, the structural failures would presumably be repaired and the likelihood of activity transport eliminated.

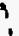

Earthquakes

The Savannah River Plant is located in an area where moderate damage might occur from earthquakes based on earthquake risk predictions by the U. S. Coast and Geodetic Survey. On the basis of 
three centuries of recorded history of earthquakes, an earthquake above the intensity of Modified Mercalli (MM) VII would not be expected at the Savannah River Plant; the decommissioned HWCTR structures may not be damaged at all by this intensity of earthquake. is:

The MM VII earthquake is defined as an earthquake whose effect

"Difficult to stand. Noticed by drivers of motor cars. Hanging objects quiver. Furniture broken. Damage of masonry of weak materials (such as adobe) or of poor mortar; masonry characterized by low standards of workmanship and weak horizontally. Some. cracks in masoniry of ordinary workmanship and mortar which is characterized as having extreme weaknesses such as failing to tie in at corners, not reinforced nor designed against horizontal forces."

\section{Dismantlement}

A reinforced concrete vault containing the reactor vessel in the burial ground would probably be undamaged by an earthquake. However, if required, the vault could be strengthened at nominal cost by pouring solid concrete around the pressure.vessel for earthquake resistance and added resistance to water penetration.

\section{Entombment}

The concrete structure for basic entombment design (Figure 14), is probably adequate to resist a MM VII earthquake. If the HWCTR building were filled with concrete, no earthquake damage would be expected.

\section{Protective Confinement}

If confinement integrity is damaged by an earthquake, release of radioactive materials would be no more severe than that shown in the release model. Such damage would only be a method for the postulated structural failures in the model. Because site surveillance and structural maintenance are associated with protective confinement, earthquake damage could be repaired before activity transport.

\section{Tornadoes}

The residual activity at the HWCTR site is primarily induced 'in large structural steel members integral with a 100-ton reactor vessel. There is no credible mechanism to transport activity in this form via tomado winds. However, tornado-generated missiles 
can be postulated to cause limited structural failures to decommissioned structures. With site surveillance and maintenance, such damage could be repaired before any activity transport via water penetration of the breach occurs. Without corrective action, the consequence sequence previously described might be initiated.

The probability of a tomado as damaging as that used in the analysis is vanishingly small. The analysis is based on tornado wind velocities of $360 \mathrm{mph}$ as postulated in Regulatory Guide 1.76. The probability of a tornado with wind velocities of $260 \mathrm{mph}$ is only $1.0 \times 10^{-4}$ per year. This is based on 22 years of tornado statistics for South Carolina and Georgia.*

\section{Dismantlement}

The components removed in dismantlement will be buried under several feet of earth in the burial ground. The pressure vessel will be further protected in a concrete vault. The combined protection of the pressure vessel by the vault and earth over- . . burden would prevent tornado damage.

\section{Entambment}

Preliminary calculations show that the roof of the basic entombment structure will not be penetrated by postulated tornado missiles; the solid entombment is even more resistant to damage.

\section{Protective Confinement}

Preliminary calculations for protective confinement indicates that the dome may be penetrated by a tomado missile. Radioactivity would still be confined; however, the penetration would only allow rainwater penetration (a leaky roof). Because protective confinement is associated with surveillance and maintenance, this dome penetration (should it ever occur) could be repaired.

The conclusion, therefore, is that the risk to any mode of decommissioning from tornadoes is negligible.

- D. W. Pepper, Tormadoes: Characteristics, Probabilities, and Consequences of Occurrence at SRP, DPST-74-563, December 20, 1974. 


\section{Floods}

Flooding of the HWCTR site or the burial ground is not credible. The grade elevation of HWCTR is $280 \mathrm{ft}$ MSL (feet above mean sea level). The burial ground grade elevation is at least $240 \mathrm{ft}$ MSL. The maximum flood level of the Savannah River is calculated to be $168 \mathrm{ft}$ MSL. Even if flooding did occur, the consequences would be less severe than the consequences from the radioactivity release model described. Such flooding would dilute the corrosion products and render them less hazardous than as described in the release model.

The maximum flood elevation, $168 \mathrm{ft}$ MSL, is calculated by methods approved in Regulatory Guide 1.59, Design Basis Floods. for Nuclear Power Plants. It is calculated from one half the probable maximum precipitation peak discharge along with simultaneous failure of all upstream dams plus maximum wave runup from a $50 \mathrm{mph}$ wind. 


\section{ASSESSMENT OF ALTERNATIVES}

The three alternatives for decommissioning HWCTR were evaluated as summarized in Table 1 , using the criteria previously developed. All are feasible and involve a very low risk of nearterm public exposure. Land area commitments in all cases are small and are currently irrelevant considering the near-term future of the SRP site. Only protective confinement would seem to require retaining long-term water rights; most licensed power reactors have selected this approach although it may also be considered as an attractive interim option. The costs are highest for dismantlement, intermediate for entombment, and modest for protective confinement. Critics have claimed that decommissioning is as costly as building nuclear facilities; however, when inflation is allowed for in HWCTR, the highest cost decommissioning mode is only $20 \%$ of the construction cost ( $\$ 9$ milition in FY 1960 . escalated to $\$ 28$ million in FY 1978), and entombment and protective confinement are proportionately lower. Flexibility ratings are lower for the entombment approach and higher for dismantlement (site reuse) or protective confinement (modify facilities or decomission differently). Aesthetics rate higher for dismantlement (and entombment) because of the appeal of grassland over manmade stmuctures visible in protective confinement. 


\section{EPILOGUE}

Some of the information required in making the HWCTR decommissioning-study was difficult to obtain. Documenting information relevant to decommissioning when a site is operational would simplify the eventual decommissioning effort.

Several examples of information that would be particularly valuable are listed below:

- Obtain analyses of the precursors of neutron activation products in structural materials. Elements of interest include vanadium, chromium, manganese, iron, cobalt, and nickel. Any material that will receive significant neutron exposure should be analyzed, including concrete shielding.

- The neutron flux distribution in regions well outside the reactor core should be calculated and perhaps measured. A three-dimensional representation would be especially useful in calculating biological shield activity. Fluxes should be related to some absolute power and exposure.

- A detailed history should be kept of plutonium released from fuel failures with estimates of the removal efficiency of the purification system.

- A history should be kept of unusual events that may lead to the deposit of neutron activation products in unexpected places, e.g., the incident involving failure of the boiling loop bayonet.

Some examples of improved data on the mechanism of activity transport from decommissioned facilities are documented to aid other studies.

- Samples of metal removed from the hydraulic system of operating reactors could be analyzed for TRU, fission products, and corrosion deposits to avoid the need to cut samples from a shutdown reactor.

- Activity release from the metal samples to water could be determined in long-term corrosion tests to confirm the activity transport rate, to determine the self-limiting effects of metal solubility, and to determine the mobile (soluble and suspended) fractions of corrosion products.

- Means of further immobilizing the activity could be investigated. 


\section{APPENDIX A}

\section{RADIATION DATA}

Radiation intensities from HWCTR in 1965 and 1969 from Health Physics survey records are compared with recent radiation measurements at the same location (Table $\vec{A}-1$ ).

TABLE A-1

Radiation Level, mR/hr at 3 inches or $\mathrm{c} / \mathrm{m}^{a}$

\begin{tabular}{|c|c|c|c|}
\hline o'J" Elevation & $1 / 11 / 65$ & $8 / 2 / 69$ & $5 / 21 / 75$ \\
\hline $\begin{array}{l}\text { Process Lines } \\
\text { Top of Spent Fuel Basin } \\
\text { Several Areas } \\
\text { Srored Equipment } \\
\text { EP } 21.2 \\
\text { Tank Top }\end{array}$ & $\begin{array}{l}6 \\
5 \\
1 \\
- \\
- \\
-\end{array}$ & $\begin{array}{l}2000 \mathrm{c} / \mathrm{m} \\
6000 \mathrm{c} / \mathrm{m} \\
6 \\
10 \\
10,000 \mathrm{c} / \mathrm{m} \\
3000-10,000 \mathrm{c}\end{array}$ & $\begin{array}{l}2000 \mathrm{c} / \mathrm{m} \\
2000 \mathrm{c} / \mathrm{m} \\
500 \mathrm{c} / \mathrm{m} \\
10 \\
1000 \mathrm{c} / \mathrm{m} \\
1000-2000 \mathrm{c} / \mathrm{s}\end{array}$ \\
\hline$-16^{\prime} 3^{\prime \prime}$ Elevation & $1 / 22 / 65$ & $8 / 22 / 89$ & $5 / 21 / 75$ \\
\hline $\begin{array}{l}\text { Right Pump Room } \\
\text { EP } 377.7 \text { Main Loop } \\
\text { EP } 21.2 \\
\text { Main System } \mathrm{O}_{2} \mathrm{O} \text { Line } \\
\text { BL Ourlet Stub } \\
\text { BL Inlet Stub } \\
\text { Process Lines Averaga } \\
\text { General Area }\end{array}$ & $\begin{array}{l}- \\
- \\
1000 \\
500 \\
35 \\
6-15\end{array}$ & $\begin{array}{l}10 \\
15 \\
10 \\
150 \\
- \\
- \\
-\end{array}$ & $\begin{array}{l}5 \\
5 \\
5 \\
60 \\
- \\
- \\
1-5\end{array}$ \\
\hline $\begin{array}{l}\text { Left Pump Room } \\
\text { Valve } 1119 \\
\text { EP } 105 \\
\text { Process Lines Average } \\
\text { General Area } \\
\text { EP } 1061-1062 \\
\text { EP } 187 \\
\text { LL Line }\end{array}$ & $\begin{array}{l}500 \\
60 \\
35 \\
3-25 \\
- \\
- \\
=\end{array}$ & $\begin{array}{l}. \\
5 \\
- \\
10 \\
15 \\
20\end{array}$ & $\begin{array}{l}\overline{3} \\
\overline{1} \\
1-5 \\
4000 \mathrm{c} / \mathrm{m} \\
8 \\
12\end{array}$ \\
\hline
\end{tabular}

$-37 ' 6$ " Elevation ..

Right Genorator Roon EP 178.1, 178.2. Average Process $35 \quad 40$

General Area

EP S4 and Adjacant Lines 800

EP 45 and Adjacent Lines 600

EP 20.1

EP 40.1 and 40.2 . General Are:

-52 '6" Elevation

$1 / 22 / 65 \quad 8 / 22 / 69$

Left Purification Roos EP 194

EP 41

EP 53

General Area

10

$2000 \mathrm{c} / \mathrm{m}$

5

Right Cyclone Roon EP 101.1 and 101 Sample lines General Area

$\begin{array}{ll}500 & 15 \\ 200 & 150 \\ 40 & 20 \\ 5 & -\end{array}$.

$1-2$

a. All radiation intensities are in $\mathrm{mR} / \mathrm{hr}$ at 3 inches from the equipment or area indicated unless otherwise identified. $4000 \mathrm{c} / \mathrm{m}=1 \mathrm{mR} / \mathrm{hr}$. 
Measurements made of the radiation emitted by the reactor vessel are listed in Tables $A-2$ and $A-3$; a short discussion of the measurements follows the data.

\section{TABLE $A-2$}

Radiation Measurements (with LND 716) in Power Level Sleeves

$\begin{array}{lll}S L V-1, & \text { Distonce from } & S L V-4, \\ m R / h r & S L V \text { Opening, ft } & m R / h r \\ & 11 & <10 \\ <10 & 12 & 15 \\ 35 & 13 & 35 \\ 100 & 14 & 130 \\ 300 & 15 & 210 \\ 500 & 16 & 210 \text { (no window) } \\ 380 \text { (carbon window) } & 17 & 150 \\ 85 & 18 & 85 \\ 20 & 19 & 35 \\ 10 & 196^{\prime \prime} & 10\end{array}$

TABLE A-3

Radiation Measurements from Reactor Tank Bottom

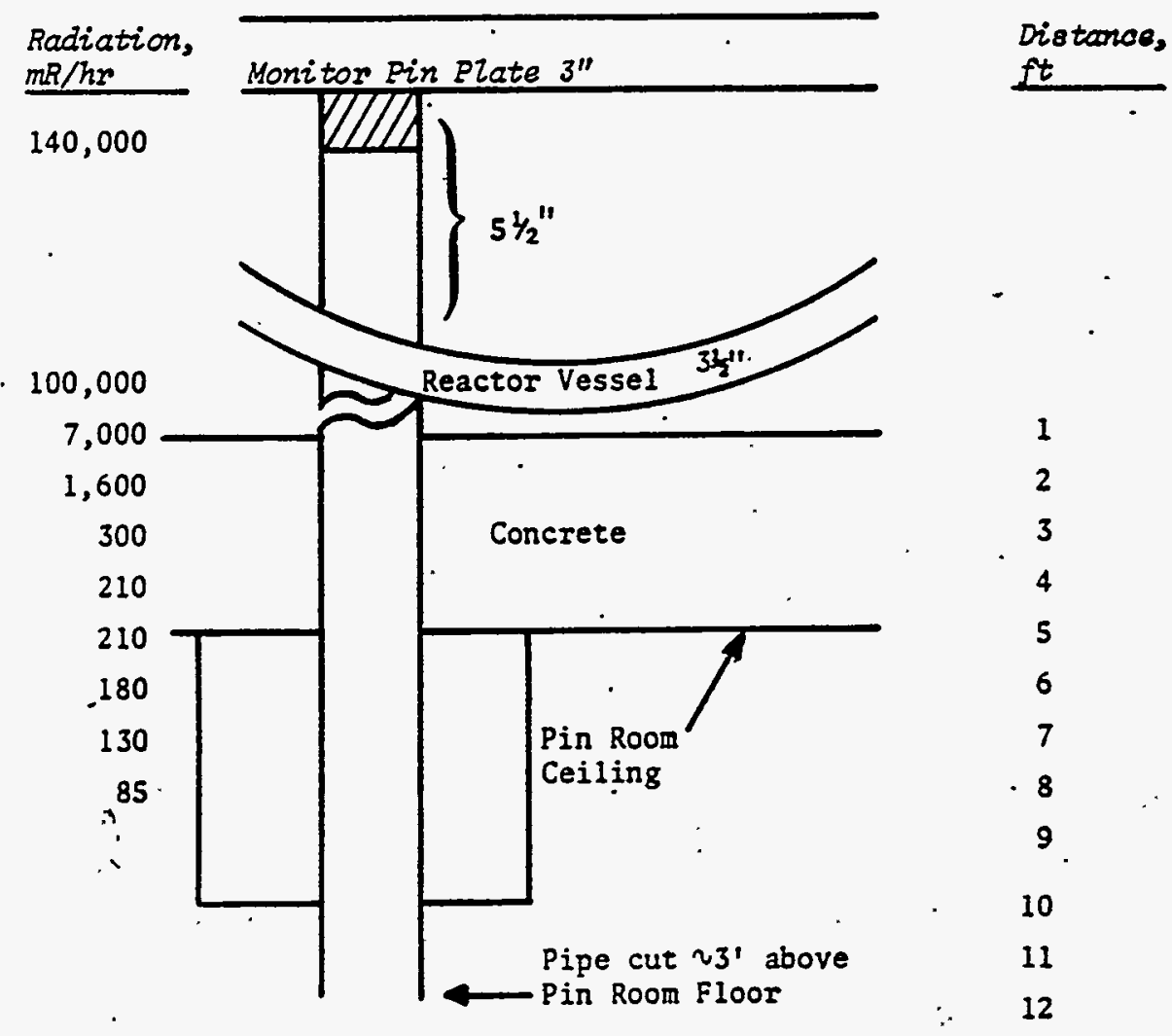




\section{Power Level Sleeve Measurements}

-In SLV-1, which has a $2 \mathrm{ft} \times 1.5 \mathrm{ft}$ window box filled with carbon adjacent to the closest point of the sleeve to the reactor tank, the maximum radiation intensity was $500 \mathrm{mR} / \mathrm{hr}$. At this point the detector was approximately 2 ft from the reactor tank. In SLV-4 at approximately the same location, the radiation intensity was $210 \mathrm{mR} / \mathrm{hr}$. SLV-4 does not have the carbon-filled window box so there is approximately $1 \mathrm{ft}$ of concrete and $1 \mathrm{ft}$ of air between this sleeve and the reactor tank.

\section{Reactor Tank Bottom}

A gamma detector (LND-716) was inserted into a 1-inch pipe in the pin room. The pipe terminates inside the reactor vessel at the bottom of the monitor pin plate. The maximum radiation intensity detected was $140 \mathrm{R} / \mathrm{hr}$ inside the tank. At the outer surface of the tank about $7 \mathrm{R} / \mathrm{hr}$ was detected. This same pipe was used by Hochel for measurements with the Ge( $\mathrm{Li}$ ) detector. system.

A portable Geli detector system was positioned at the end of. the beam tube approximately $20 \mathrm{ft}$ below the bottom of the reactor to identify the gamma emitters present. The only gamma emitter detectable was ${ }^{8}{ }^{\circ} \mathrm{Co}$ and the activity was calculated to be $1.9 \times$ $10^{7} \mathrm{~d} / \mathrm{s} / \mathrm{g}$ assuming that the beam pipe end cap was 3 inches thick and that there was equal distribution of ${ }^{60} \mathrm{Co}$.

\section{Piping Samples}

Data gathered from analyses of samples from the moderator systems of HWCTR are included in Tables A-4 and A-5. Estimates of total radioactivity in the various parts of the system are order of magnitude estimates. 


\section{TABLE A-4}

HWCTR Moderator System Sample Data

Sample Lucations

(10" line) Main System

(4"line) Liquid Loop

(4" line) Boiling loop

Process Water

Hold Tank (EP 41)

Scomple

3" metal plug*

1.25" metal plug

1.25 " metal plug

Two 'smears
Portable Instrionent Survey

$30,000 \mathrm{c} / \mathrm{m} \mathrm{Br}$

$4,000 \mathrm{c} / \mathrm{m} \mathrm{Br}$

$15 \mathrm{mrad} / \mathrm{hr}$ at $3^{\prime \prime}$.

$25 \mathrm{mrad} / \mathrm{hr}$ at $3^{\prime \prime}$

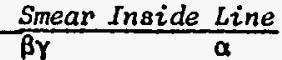

$1100 \mathrm{c} / \mathrm{m}$

\section{$1300 \mathrm{c} / \mathrm{m}$}

$15 \mathrm{mrad} / \mathrm{hr}$ at $3^{\prime \prime}$

Same as sample $\frac{\text { Analysis by Analytical Chemistry (PHA), }}{\text { TRU }} \frac{d / m}{60 \mathrm{Co}}$

$3.3 \times 10^{3}$

$6 \times 10^{3}$

$10^{4}$

$6.6 \times 10^{5}$

$2.8 \times 10^{5}$
$<9 \times 10^{2}$

9.9. $\times 10^{6}$

$<3.7 \times 10^{2}$

$<9 \times 10^{2}$

$2 \times 10^{5}$

$6 \times 10^{5}$
$1.3 \times 10^{6}$

$8.4 \times 10^{6}$

$1.5 \times 10^{7}$

$3.6 \times 10^{7}$

- 3" diameter plug 
TABLE A-5

HWCTR Moderator System Radioactivity

\begin{tabular}{|c|c|c|c|c|c|c|c|}
\hline \multirow[b]{2}{*}{ Sysitem } & \multirow[b]{2}{*}{ Area $f t^{2 b}$} & \multicolumn{3}{|c|}{ Contamination $/ f t^{2}, d / m$} & \multicolumn{3}{|c|}{ Estimated Total Contamination, $\mathrm{Ci}^{a}$} \\
\hline & & $T R U^{c}$ & $237 \mathrm{Cs}$ & ${ }^{60} \mathrm{Co}$ & TRU & ${ }^{137} \mathrm{Cs}$ & ${ }^{60} \mathrm{CO}$ \\
\hline Main System. & 5660 & $66 \times 10^{3}$ & $<18 \times 10^{2}$ & $198 \times 10^{6}$ & $169^{\circ} .8 \times 10^{-6 d}$ & $<0.6 \times 10^{-6}$ & 0.5 \\
\hline Liquid Loop & 700 & $720 \times 10^{3}$ & $<44.4 \times 10^{3}$ & $166 \times 10^{6}$ & $229 \times 10^{-6}$. & $<14 \times 10^{-6}$ & .05 \\
\hline Boiling Loop & 700 & $120 \times 10^{4}$ & $<10.9$ & $1 \times 10^{9}$ & $381.8 \times 10^{-6}$ & $<35 \times 10^{-6}$ & 0.32 \\
\hline $\begin{array}{l}\text { Process Water } \\
\text { Hold Tank EP }\end{array}$ & $61.5^{e}$ & $9.4 \times 10^{5}$ & $4 \times 10^{5}$ & $2.5 \times 10^{7}$ & $26.3 \times 10^{-6}$ & $11 \times 10^{-6}$ & $696 \times 10^{-6}$ \\
\hline & & & & Total & $806.9 \times 10^{-6}$ & $11 \times 10^{-6}$ & 0.87 \\
\hline
\end{tabular}

a. Based on the assumption that the contamination on the sample is representative of that in the system.

b. Appendix C

c. $\sim 90 \%{ }^{239} \mathrm{Pu}$ and $108^{238} \mathrm{Pu}$

d. This is equivalent to $0.001 \times 10^{-9} \mathrm{Ci} / \mathrm{g}$ of pipe

e. Area contaminated was assumed to be a.strip covered with visible particulates $\sim 3$ ' wide along the bottom of 


\section{Transferable Contamination}

Health Physics completed a random disc smear survey of the zero level using about 150 disc smears. Smears were taken on the inside walls of the dome and equipment that could be reached from the floor or the first platform to the overhead crane. All of the smears were below the scaler background of $10 \mathrm{c} / \mathrm{m} \mathrm{Br}$ and $3 \mathrm{c} / \mathrm{m} \alpha$ with the exception of two smears in the vicinity of the tank top. These two smears were contaminated to 18 and $42 \mathrm{c} / \mathrm{m}$ $\mathrm{B \gamma}$. No surveys were made of the dome or equipment at higher elevations because of poor lighting and means of access and may not be necessary until actual disassembly and removal of equipment begins. The fuel storage basin is covered with wood and a tarpaulin which were installed after reactor discharge. Health Physics survey records. indicate that the basin was contaminated to $100 \mathrm{mrad} / \mathrm{hr}$ prior to the last flush before it was covered. Paper towel smears of the inside of the spent fuel basin indicated $<100 \alpha d / m / f t^{2}$ and 200-400 By c/m/ft ${ }^{2}$ on the walls and 400$600 \mathrm{Br} \mathrm{c} / \mathrm{m} / \mathrm{ft}^{2}$ on the floor areas. . A portable instrument lowered to the $-27^{\prime}$ elevation of the basin floor indicated $15 \mathrm{mrad} / \mathrm{hr}$ at 2 inches.

Transferable contamination on external surfaces in process areas below the zero elevation is generally less than $500 \mathrm{Br}$ $\mathrm{c} / \mathrm{m} / \mathrm{ft}^{2}$ and less than $100 \alpha \mathrm{d} / \mathrm{m} / \mathrm{ft}^{2}$. However, radiation survey records for scheduled work since the facility was shut down show that $\alpha$ contamination in the order of $40-50 \alpha \mathrm{d} / \mathrm{m} / 100 \mathrm{~cm}^{2}$ to a maximum of $350 \alpha \mathrm{d} / \mathrm{m} / \mathrm{ft}^{2}$ has been detected during line breaks, etc.

$+$ 


\section{APPENDIX B}

\section{DERIVATION OF CONCENTRATION LIMITS}

\section{Dose Commitment}

At SRP, the dose-to-man resulting from the release of radioactive species is calculated on the basis of the total dose over a 70-year period that results from a single year's release of the species. This concept is important when the combination of biological retention of the nuclide in the body and the nuclide's radioactive half-life result in a long-term effect from a shortterm uptake. This is illustrated in the case of ${ }^{63} \mathrm{Ni}$ shown below.

${ }^{6} \mathrm{Ni}$

Radioactive half-life

Biological half-life

Critical organ

SRP Tech. Std. dose

Limiting concentration in drinking water
100 years

800 days

bone

$30 \mathrm{mrem} / \mathrm{yr}$

$5 \times 10^{-7} \mu \mathrm{Ci} / \mathrm{cc}$

The cumulative dose for two hypothetical cases are given below. Case 1, one-year ingestion of the water is assumed; and Case 2; time is extended to 15 years. 


\section{Case 1}

Drinking $1200 \mathrm{cc} /$ day of water with ${ }^{6} \mathrm{Ni}=5 \times 10^{-7} \mu \mathrm{Ci} / \mathrm{cc}$, for one year.

$\begin{array}{lllllllllllllllllllll}\text { Year } & 1 & 2 & \cdots & 3 & 4 & 5 & 6 & 7 & 8 & 9 & 10 & 11 & .12 & 13 & 14 & 15 & \text { Total }\end{array}$

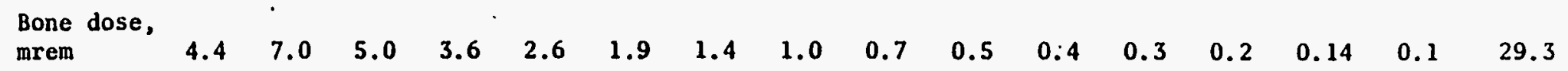

\section{Case 2}

Drinking $1200 \mathrm{cc} /$ day of water with ${ }^{6}{ }^{3} \mathrm{Ni}=5 \times 10^{-7} \mu \mathrm{Ci} / \mathrm{cc}^{\mathrm{c}}$, for 15 years.

$\begin{array}{lllllllllllllllllll}\text { Year } & 1 & 2 & 3 & 4 & 5 & 6 & 7 & 8 & 9 & 10 & 11 & 12 & 13 & 14 & 15 & \text { Total }\end{array}$

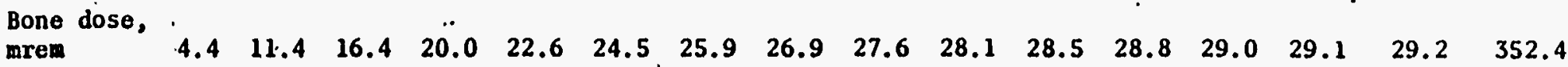


In Case 1, the total dose commitment was $29.3 \mathrm{mrem}$, with a maximum annual dose of 7.0 mrem. In Case 2 , the maximum was 29.2 mrem; with a total of $352.4 \mathrm{mrem}$. Continued intake beyond 15 years would result in a constant annual dose of $29.3 \mathrm{mrem}$. The Technical Standard requires that no annual exposure exceed $30 \mathrm{mrem}$; setting the limiting concentration on the basis of the dose commitment assures this (Case 2), but is conservative if releases are discontinued before the steady-state dose rate is reached (Case 1).

\section{Concentration Limits}

The 70-year dose commitment from ingestion of a radionuclide is given by

$$
\operatorname{Dose}_{70}=D_{C} \times C
$$

where

$$
\begin{aligned}
& \mathrm{C}=\text { concentration in water, } \mu \mathrm{Ci} / \mathrm{Cc} \\
& \mathrm{D}_{C}=\text { dose conversion factor. }
\end{aligned}
$$

For the whole body and any organ except the GI tract,

$$
D_{c}=\frac{k f \varepsilon}{m \lambda}\left(1-e^{-2.555 \times 10^{4} \lambda}\right)
$$

where

$$
\begin{aligned}
& k=\text { a constant related to rate of intake } \\
& f=\text { fraction of radionuclide that reaches organ of } \\
& \varepsilon=\text { interest } \\
& m=\text { mass of organ of interest, } g \text { interest, } \mathrm{MeV}^{-1} \\
& \lambda=\text { effective decay constant, days }
\end{aligned}
$$

$\left(\lambda=\lambda_{F}+\lambda_{b}\right.$, where $\lambda_{r}=$ radioactive decay constant and $\lambda_{b}=$ biological decay constant) $2.555 \times 10^{4}=$ days in 70 years.

For the GI tract,

$$
D_{c}=\frac{k f \varepsilon T e^{-\lambda}}{\mathfrak{m} t}
$$

where

$k=a$ constant depending on mode of intake

$T$. = residence time in portion of GI tract involved, days

$t=$ time for ingested material to reach portion of $G I$ tract considered, days

Other constants are defined for Equation B-2. 
In calculating the dose from eating fish, the $D_{c}$ value is multiplied.by a concentration factor to convert $\mu \mathrm{Ci} / \mathrm{cc}$ of water to $\mu \mathrm{Ci} / \mathrm{g}$ of fish in equilibrium with water. The concentration factors vary depending on the element being considered.

Dose conversion factors for the nuclides of concern in the HWCTR were either obtained from Reference 1 or çalculated using the parameters given below.

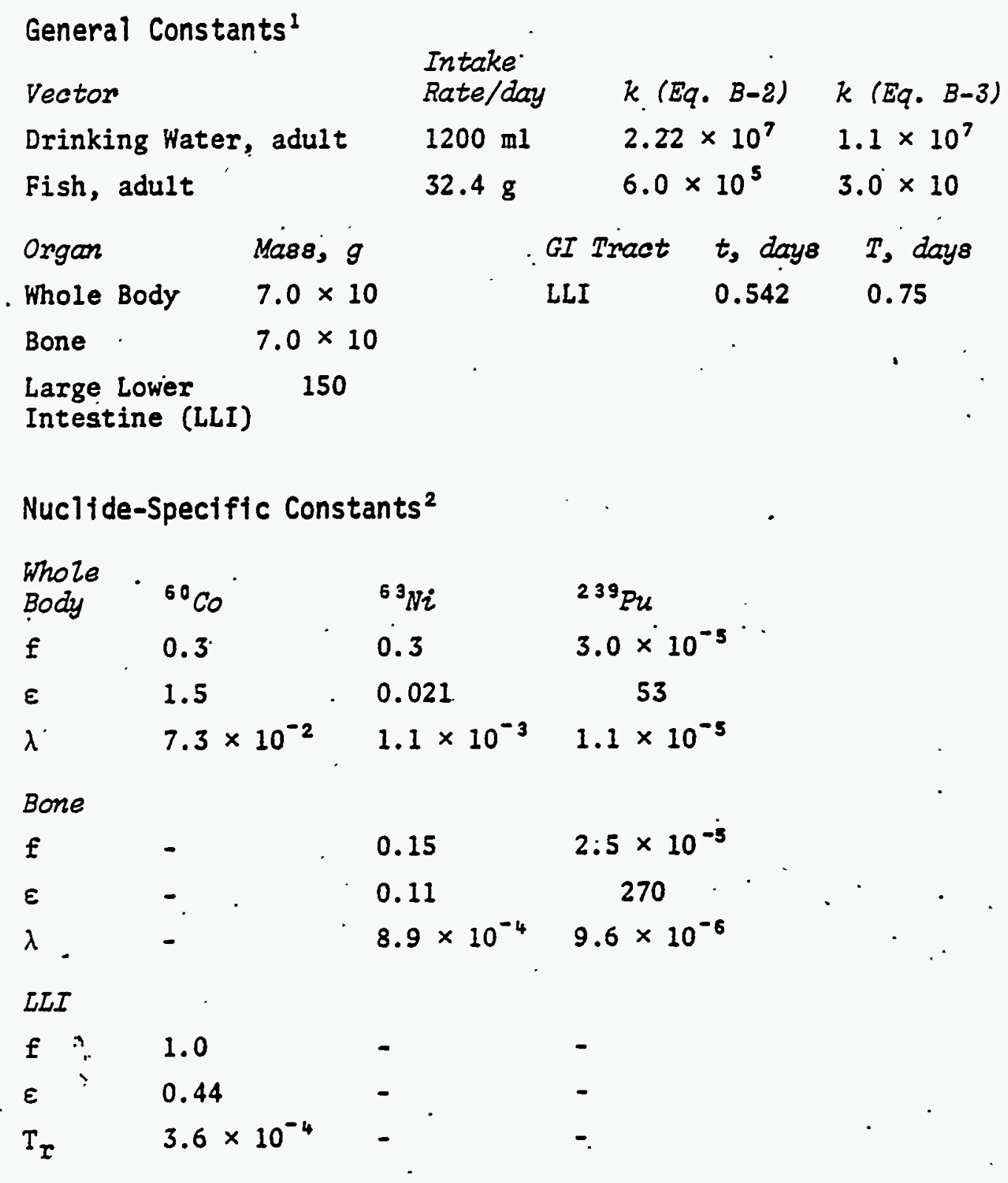


Concentration Factors in Fish ${ }^{3}$

$\begin{array}{lc}\text { Element } & \text { Factor } \\ \mathrm{Co} & 20 \\ \mathrm{Ni} & 100 \\ \mathrm{Pu} & 3.5\end{array}$

Dose Conversion Factors

Whole Body $\quad{ }^{60} \mathrm{CO}$

$\begin{array}{lllr}\text { Drinking Water } & 2000 & 1800 & 11,000 \\ \text { Eating Fish } & 1060 & 4900 & 4,000\end{array}$

Bone

Drinking Water. - $59,000470,000^{1}$

Eating Fish - 160,000 200,000

GI TRACT (LLI)

Drinking Hater 24,200

Eating Fish . 13,200

The dose conversion factors were then used in Equation

$\mathrm{B}-1$, together with the limiting dose, to determine the appropriate concentration limits for this study. The whole body dose also contributes to the specific organ dose and must be included in determining total dose. Equation B-1, thus took the general form:

$$
c_{W}=\frac{0.03}{D_{c_{1}}+D_{c_{2}}+D_{c_{3}}+D_{c_{4}}}
$$

where

$\mathrm{C}_{w}=$ concentration in water, $\mathrm{Ci} / \mathrm{cc}$

$D_{C^{2}}{ }^{W}=$ dose conversion factor, specific organ, for drinking water.

$D_{C 2}=$ dose conversion factor, specific organ, for eating fish

$D_{C S}=$ dose conversion factor, whole body, for drinking water

$D_{c i}=$ dose conversion factor, whole body, for eating fish

$0.03=$ mrem limit for bone or LLI

For the case of drinking water only, $D_{c^{2}}$ and $D_{c^{4}}$ are deleted. The concentration limits calculated using Equation B-4 are given as follows: 
Nuclide $\frac{C_{w,} \mu C i / m l}{\text { Drinking Water Only Drinking Water and Fish }}$

$\begin{array}{lll}{ }^{60} \mathrm{Co} & 1.1 \times 10^{-6} & 7.4 \times 10^{-7} \\ { }^{6}{ }^{3 \mathrm{Mo}} & 4.9 \times 10^{-7} & 1.3 \times 10^{-7} \\ { }^{239} \mathrm{Pu} & 6.2 \times 10^{-8} & 4.4 \times 10^{-8}\end{array}$

The resulting maximum annual doses at these concentrations are given as follows:

Drinking Water Only

Nuclide

mrem/yr

${ }^{60} \mathrm{Co}$

Whole Body

2.2

Bone

LII Total to Organ

${ }^{6} \mathrm{Ni}$

0.9

0.7

$-$

26.6

28.8

${ }^{2}{ }^{39} \mathrm{Pu}$

28.9

$-\quad 29.8$
$-\quad 30.0$

Water and Fish

${ }^{60} \mathrm{Co}$

2.3

29.3

$-\quad 30.0$

$6{ }^{3} \mathrm{Ni}$

0.9

$-$

27.7

30.0

${ }^{2}{ }^{39} \mathrm{Pu}$

0.7

28.5

29.4

29.5

30.2

\section{REFERENCES}

1. "Appendix G - "Methods for Determining Environmental Radiation Dose," Environmental Statement - Waste Management. Operations. Savannah River Plant, Aiken, South Carolina (Draft) USERDA Report ERDA-1537 (to be issued).

2. "ICRP Publication," Health Physics 3, June 1960.

3. S. E. Thompson, et al. Concentration Factors of Chemical Elements in Edible Aquatic Organisms, UCRL-50564, Rev. 1, October 1972. 


\section{APPENDIX C}

MISCELLANEOUS EQUIPMENT DESCRIPTION

A. Reactor Vessel and Internal Parts (EP-I)

1. References

BPF 210650

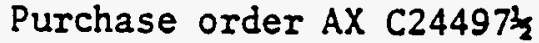

W230739

PASECO supplied vessel and internal parts.

2. Weight

The purchase order states that the calculated weight of the vessel and all internal parts is 98 tons (this excludes fuel but includes all other internals). Calculations made as a part of this study indicate the vessel weights 50 to 55 tor's, and the 'internals weigh about 27 tons. The calculated weight of the internal parts is as follows:

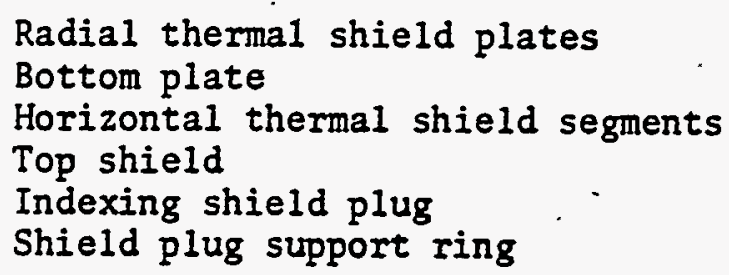

Pounds

24,400

1,600

7,000

5,600

7,800

8,000

Total 54,400

\section{B. Lower Axial Shield}

1. References

BPF 210650 (Part of EP-1)

W231697

D111481

2. Size

$58^{\prime \prime}$ OD $\times 37^{\prime \prime}$ high 
3. Contents and Weight

The space among sleeves is filled with concrete. A memo from Kamack to Overbeck dated 9/28/61 apparently supersedes the drawings regarding concrete fill. The memo specifies the fill composition as follows:

\section{Pounds}

Steel shot

Portland cement, Type 1

8,507

848

Water

331

Total 9,747

The drawings specified only concrete as the fill.

The empty weight of the shield is specified as $25001 \mathrm{~b}$ on D111481; the total weight is about 12200 Ib (D111481 also specifies a concrete fill volume of $42 \mathrm{ft}^{3}$, concrete density of $332 \mathrm{lb} / \mathrm{ft}^{3}$, and a filled assembly weight of 4550 . This weight is inconsistent with the volume and density; the volume appears to be correct

and the weight wrong.)

4. Material

The shield is constructed of carbon steel. D111841 specified cadmium plating the sleeve inner surfaces and painting the exterior of the shell.

5. The shield is supported by 12 support lugs that form a segmented ring. The lugs are bolted to the pin room ceiling. 
C. Steam Generators (EP 20.1 and 20.2)

1.- References

BPF 120628

2. Description

- Empty weight

37,800 1b each

- Heat transfer. surface area

$2,500 \mathrm{ft}^{2}$ each

- Tubes

3/4" OD, 12 BWG, 0.109" wall

ASTM SA-210 carbon steel

- She11

$1-1 / 8$ " thick wall
$2-3 / 8$ " thick head

- Minimum carbon steel 10" Sch. $60^{\circ}$ weld caps, $0.500^{\prime \prime}$ wall thickness to penetrate shell

$2 "$ drain pipe, $0.30^{\prime \prime}$ wall

D. Main System 10" Piping

1. Outside Biological Shield

- 'Sch. 100, 0.718" wall

- ASTM A106 Grade B carbon steel

- 220 ft purchased

- All connections are welded

2. Inside Biological Shield

- Sch. 100304 stainless steel

- 24 ft purchased 


\section{APPENDIX D}

PARTIAL LIST OF REFERENCE NUMBERS FOR HWCTR EQUIPMENT

\begin{tabular}{|c|c|c|c|c|}
\hline Name & $\begin{array}{l}\text { Equipme } \\
\text { (EP) } \mathrm{Nz}\end{array}$ & $\begin{array}{l}\text { ent Piece } \\
\text { omber }\end{array}$ & $\begin{array}{l}\text { Blue Pri } \\
\text { (BPF) } \mathrm{Nu}\end{array}$ & $\begin{array}{l}\text { it File } \\
\text { nber }\end{array}$ \\
\hline Reactor Vessel & 1 & & 210650 & \\
\hline Steam Generators & 20.1 & 20.2 & 210628 & \\
\hline Main Storage Tank & 41 & & 210588 & \\
\hline Main Pumps & 21.1, & 21.2 & 210652 & \\
\hline Gas Compressors & 86.1 & 86.2 & 210953 & 210954 \\
\hline ICL Storage Tank & 194 & & & \\
\hline Makeup Pump & 42 & & 210610 & \\
\hline SFB Deionizer & 103 & & 210757 & \\
\hline SFB Filter & 104 & · & & \\
\hline LL Pumps & 186.1. & 186.2 & 211251 & \\
\hline BL Pumps & 178.1 & 178.2 & 210651 & ' \\
\hline Main System Deionizer & 44.1, & 44.2 & 210757 & \\
\hline Main Purge Cooler & 40.1 & 40.2 & $\bullet$ & \\
\hline Seal Pot & 43 & & 210698 & \\
\hline Hold Tank & 105 & & 210821 & \\
\hline LL Cooler & 187 & . & & \\
\hline Hold Tank & 53 & & 210821 & \\
\hline SFB Cooler & 101.1 & 101.2 & 210760 & \\
\hline Drain Tank & 51 & & & \\
\hline Purification Tank & 47 & $\cdot$ & 210682 & \\
\hline Catch Pot & 92 & . & 210786 & \\
\hline ICL Seal Pump & 180 & 195 & & \\
\hline ICL Afterfilter & 45 & $:$ & 210740 & \\
\hline LL Purge Cooler & 191 & & ' & \\
\hline Transfer Coffin & 270 & & & \\
\hline Rod Drive Platform & 256 & . & & \\
\hline Spent Fuel Basin Gantry & 278 & & & \\
\hline Reactor Vessel & 1 & & 210650 & \\
\hline Steam Generators & 20.1 & 20.2 & 210628 & \\
\hline
\end{tabular}




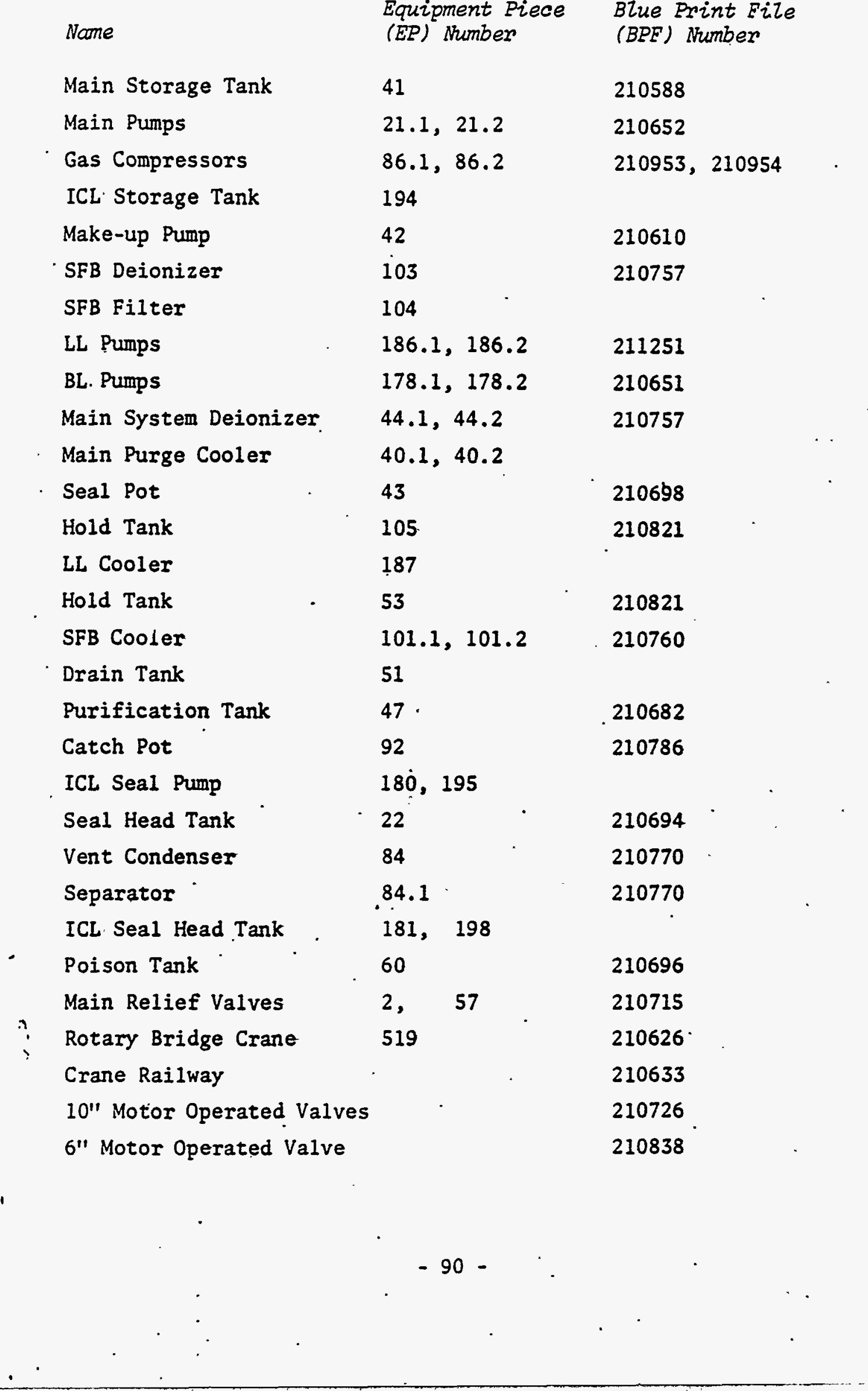


Abbreviations

ICL Isolated Coolant Loop

LL Liquid Loop

$\mathrm{BL} \quad$ Boiling Loop

SFB $\quad \cdot \quad$ Spent Fuel Basin

$?$

1

- 91. - 


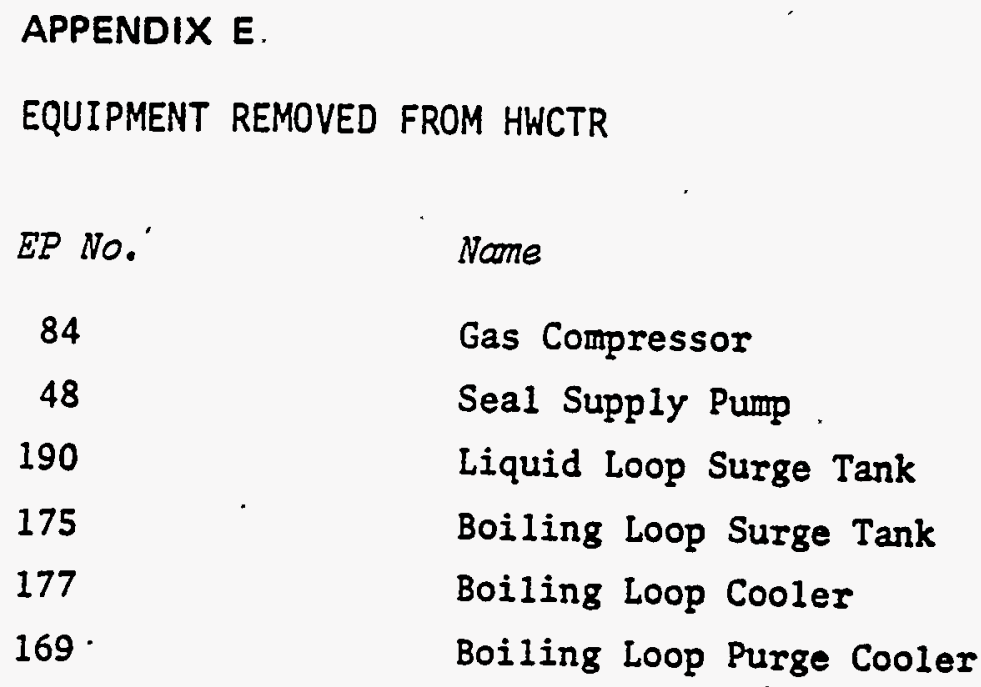

$$
\because
$$




\section{APPENDIX F}

\section{SURFACE AREAS OF PROCESS EQUIPMENT}

1. Surface Exposed to $D_{2} O$ (for alpha activity estimate)

a. Carbon Steel Piping

$10^{\prime \prime}$ Main Loop Pipes, 250 ft, $660 \mathrm{ft}^{2}$

Pressure Relief and Vent Pipes

$$
\begin{array}{r}
12^{\prime \prime}, \sim 33 \mathrm{ft}, 104 \mathrm{ft}^{2} \\
8^{\prime \prime}, \sim 60 \mathrm{ft}, 126 \mathrm{ft}^{2}
\end{array}
$$

b. Steam Generators (tube side), $2500 \mathrm{ft}^{2}$ each (carbon steel tubes)

c. Reactor Vessel, $\sim 800 \mathrm{ft}^{2}$ (stainless stee1)

d. Reactor Internal Parts, $1500 \mathrm{ft}^{2}$ (normally submerged)

e. Purge Cooler (EP 40) $2600 \mathrm{ft}^{2}$ (carbon steel tubes).

f. Liquid Loop

Cooler (EP 187)

Piping

$$
\begin{array}{r}
65 \mathrm{ft}^{2} \\
500 \mathrm{ft}^{2}
\end{array} \text { stainless steel }
$$

g. Boiling Loop
Piping
$500 \mathrm{ft}^{2} \mathrm{\}}$ stainless steel

2. Stainless Steel Surface in Reactor Vessels (for ${ }^{6}{ }^{3} \mathrm{Ni}$ release models)

a. Inner surface of thermal shield plates having the maximum specific activity of ${ }^{60} \mathrm{Co}$ and ${ }^{6}{ }^{3} \mathrm{Ni}(5 \times \mathrm{avg})$ :

\section{Square Feet}

\begin{tabular}{lr} 
Side plates & 160 \\
Angle plates & 37 \\
Bottom plate & 14 \\
Top plate & 14 \\
\hline
\end{tabular}

b. Outer surface of thermal shield. and reactor lining surface (in core region) having ${ }^{60} \mathrm{Co}$ and ${ }^{63} \mathrm{Ni}$ specific activity 100 times lower than inner surface of thermal shield plates:

$$
\text { Area }=567 \mathrm{ft}^{2} \text {. }
$$


c. Additional stainless steel surface area in reactor in upper region above the active core (assuming all surfaces submerged):

$$
\text { Area }=v 1500 \mathrm{ft}^{2}
$$

d. Weighted average ${ }^{63} \mathrm{Ni}$ and ${ }^{60} \mathrm{Co}$ specific activity, including nonactive stainless steel in reactor:

- Include all stainless steel in core region.

$$
\begin{aligned}
&(\mathrm{SA})_{\mathrm{WA}}=(\mathrm{SA})_{\max } \frac{1 \times 225 \mathrm{ft}^{2}+0.01 \times 567 \mathrm{ft}^{2}}{225 \mathrm{ft}^{2}+567 \mathrm{ft}^{2}} \\
& \begin{aligned}
&(\mathrm{SA})_{\mathrm{WA}}=(\mathrm{SA})_{\max } \quad(0.3) \\
& \text { where: } \quad(\mathrm{SA})_{\max }= \begin{array}{l}
\text { maximum surface } \\
\text { specific activity }
\end{array} \\
&(\mathrm{SA})_{\mathrm{WA}}=\begin{array}{l}
\text { weighted average surface } \\
\text { specific activity }
\end{array}
\end{aligned}
\end{aligned}
$$

- Include all stainless steel in reactor.

$$
\begin{aligned}
& (S A)_{W A}=(S A)_{\max } \cdot \frac{1 \dot{x} 225 \mathrm{ft}^{2}+0.01 \times 567 . \mathrm{ft}^{2}}{225 \mathrm{ft}^{2}+567 \mathrm{ft}^{2}+15.00 \mathrm{ft^{2 }}} \\
& (\mathrm{SA})_{\mathrm{WA}}=(\mathrm{SA})_{\max }(0.10)
\end{aligned}
$$

- Note that $(S A)_{\max }=5 \times(S A)_{\text {avg }}$. . where $(S A)_{a v g}=$ average specific activity of stainless

- The units of (SA) are $\mu \mathrm{Ci} / \mathrm{g} . \mathrm{Fe}$.

e. The significance and application of the weighted average specific activity (SA) WA derived in item d'above are as follows:

- Release of ${ }^{60} \mathrm{Co}$ or ${ }^{63} \mathrm{Ni}$ depends on corrosion of the stainless steel. 
- The maximum ${ }^{60} \mathrm{Co}$ or ${ }^{63} \mathrm{Ni}$ content of the water in the reactor vessel is determined by the saturation concentration of $\mathrm{Fe}$ in the water and the weighted average specific activity of ${ }^{60} \mathrm{Co}$ or ${ }^{63} \mathrm{Ni}$ in the stainless steel; e.g.,

$$
\mu \mathrm{Ci}{ }^{63} \mathrm{Ni} / \mathrm{cc} \mathrm{H}_{2} \mathrm{O}=\frac{\mu \mathrm{Ci}{ }^{63} \mathrm{Ni}}{\mathrm{g} \mathrm{Fe}} \times \frac{\mathrm{g} \mathrm{Fe}}{\mathrm{cc} \mathrm{H}_{2} \mathrm{O}}
$$

This assumes that all of the $\mathrm{Ni}$ and $\mathrm{Co}$ released by corrosion of stainless steel dissolve in the water.

- Exposing more nonactive stainless steel or Fe to the water lowers (SA) WA and lowers the content of ${ }^{\circ} \mathrm{CO}$ and ${ }^{6} \mathrm{Ni}$ in the water.. The ratio $(\mathrm{SA})_{\mathrm{HA}}=0.3(\mathrm{SA})_{\max }$ was used in the activity release calculations.

- One way to reduce the potential ${ }^{60} \mathrm{Co}$ or ${ }^{63} \mathrm{Ni}$ content of the water would be to fill the reactor with iron (e.g., steel pipes).

$?$

:

$-95-$. 


\title{
APPENDIX G
}

\section{REFEREIVCES}

\author{
W230739 - Cross Section of Reactor \\ W231080 - Reactor Piping Imbedded in Concrete, Plan \\ W231081 - Reactor Piping Imbedded in Concrete, Section \\ W231292 - Concrete around Reactor \\ W231697 - Lower Axial Shield \\ D111481 - Lower Axial Shield \\ W230829 Equip. Arrgt. at E1. O'-0'" \\ W230849 - Equip. Arrgt. at E1. $-16^{\prime}-3^{\prime \prime}$ \\ W230850 - Equip. Arrgt, at E1, $-37^{\prime}-6^{\prime \prime}$ \\ W230851 - Equip. Arrgt. at E1. -52'-6" \\ W230916 - Equip. Arrgt. at E1. Sections \\ W230889 - Equip. Arrgt. at E1. Sections \\ W230917 - Equip. Arrgt. at E1. Sections \\ W230856 - Spent Fue1 Basin \\ W168483 - Transfer Coffin \\ Map 3420, Sht. 1 - Plot Plan \\ Mode1 - HWCTR Model is in the 773A Fab Lab
}

DPSTN 2535 contains

a. Historical memos/letters on HWCTR decommissioning

b. 1975 memos on HWCTR decommissioning

c: Miscellaneous HWCṬR memos

d. Calculations

e. Notes

f. HWCTR photograph numbers

g. HWCTR drawing schedule 